\title{
PUISI NASIHAT AZ-ZAINABIYYAH \\ IMAM ALI IBN ABI TALIB R.A. \\ DALAM "DIWAN IMAM ALI": \\ ANALISIS SEMIOTIK
}

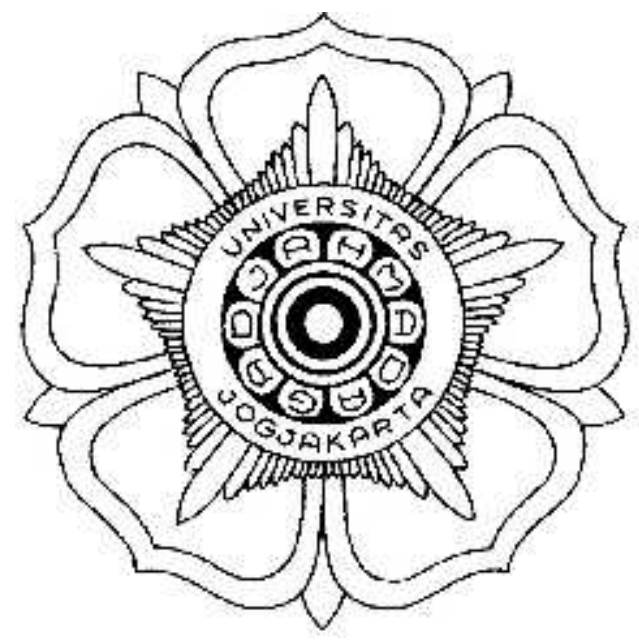

Disusun oleh:

\begin{abstract}
Moch. Lukluil Maknun
02/160009/SA/12447
\end{abstract}

\section{PROGRAM STUDI SASTRA ASIA BARAT \\ FAKULTAS ILMU BUDAYA \\ UNIVERSITAS GADJAH MADA \\ YOGYAKARTA \\ 2006}




\section{PUISI NASIHAT AZ-ZAINABIYYAH \\ IMAM ALI IBN ABI TALIB R.A. \\ DALAM "DIWAN IMAM ALI": \\ ANALISIS SEMIOTIK}

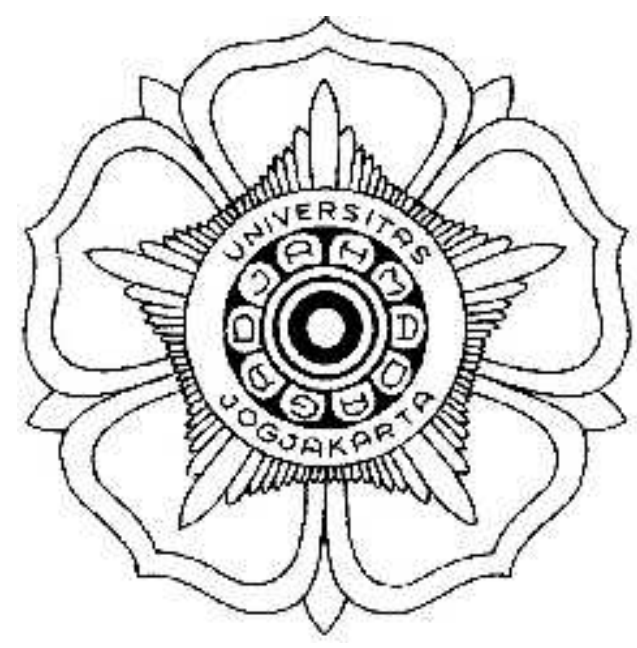

Disusun oleh:

\section{Moch. Lukluil Maknun 02/160009/SA/12447}

\section{Pembimbing:}

Dra. Hindun, M. Hum.

Skripsi ini diajukan kepada panitia ujian Fakultas Ilmu Budaya Universitas Gadjah Mada Yogyakarta sebagai salah satu syarat untuk mendapatkan gelar sarjana dalam Ilmu Sastra Arab 
2006

Skripsi

\section{PUISI NASIHAT AZ-ZAINABIYYAH}

Imam Ali Ibn Abi Talib R.a. dalam “Diwan Imam Ali”:

Analisis Semiotik

\section{Moch. Lukluil Maknun \\ 02/160009/SA/12447}




\section{HALAMAN PENGESAHAN}

Skripsi ini telah diterima oleh panitia ujian Fakultas Ilmu Budaya Universitas Gadjah Mada pada tanggal 11 Januari 2006 dan telah diujikan di hadapan dewan penguji pada tanggal 17 Januari 2006.

Mengetahui, Ketua Jurusan Sastra Asia Barat Fakultas Ilmu Budaya UGM

Dr. Amir Ma'ruf, M. Hum.

Drs. Fadlil Munawwar Manshur, M.S.

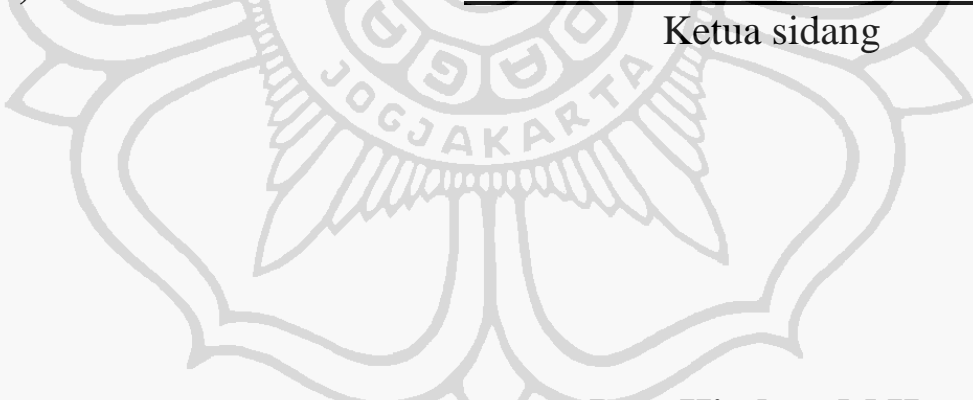

Dra. Hindun, M.Hum Sekretaris

Dr. Sangidu, M. Hum.

Penguji utama 


\section{PERNYATAAN}

Yang bertanda tangan di bawah ini, saya:

Nama $\quad$ : Moch Lukluil Maknun

Jurusan/ Prodi : Sastra Asia Barat

Fakultas : : Ilmu Budaya

Nim $\quad: 12447$

Judul Skripsi : Puisi Nasihat az-Zainabiyyah Imam Ali ibn Abi Talib R.a. dalam "Diwan Imam Ali”: Analisis Semiotik.

Menyatakan bahwa skripsi ini benar-benar hasil karya saya sendiri dan sepanjang pengetahuan saya tidak berisi materi yang ditulis atau dipublikasikan orang lain atau sebagai persyaratan penyelesaian studi di Perguruan Tinggi ini kecuali sebagai acuan atau kutipan dengan mengikuti tata penulisan karya ilmiah yang telah lazim.

Yogyakarta, Januari 2006

Moch. Lukluil Maknun 


\section{MOTTO dan PERSEMBAHAN}

$$
\text { بيّين بما }
$$

(Q. S. Ali Imran:79)

\section{Aku persembahkan skripi ini kepada}

Segenap guru, penempa ruhku

Ibu dan Ayahku, penempa jiwa-ragaku

Saudara-saudaraku, penempa semangatku

Sahabat-sahabatku, penempa hidupku

\section{KATA PENGANTAR}


Alhamdulillah, segala puji hanya bagi Allah, Dzat yang mengajarkan Adam nama-nama, mengajarkan Sulaiman bahasa binatang, dan mengajar manusia apa yang belum diketahui. Atas limpahan nikmat-Nya penulis mampu menyelesaikan penulisan skripsi dengan judul Puisi Nasihat az-Zainabiyyah Imam Ali ibn Abi Talib R.a. dalam "Diwan Imam Ali": Analisis Semiotik. Penyusunan skripsi ini dalam rangka memenuhi salah satu syarat memperoleh gelar Sarjana Sastra di Fakultas Ilmu Budaya Universitas Gadjah Mada Yogyakarta.

Penyusunan skripsi ini tidak lepas dari bantuan dan dorongan berbagai pihak baik secara moral maupun material. Oleh karena itu penulis ingin menyampaikan terima kasih banyak dan penghargaan setinggi-tingginya kepada:

1. Prof. Dr. Syamsul Hadi, SU, M.A. selaku Dekan Fakultas Ilmu Budaya Universitas Gadjah Mada Yogyakarta, yang telah memberi kesempatan penulis untuk menimba pengetahuan di fakultas ini.

2. Dr. Amir Ma'ruf, M.Hum. selaku ketua Jurusan Satra Asia Barat, yang telah berkenan menyetujui dilaksanakannya penyusunan skripsi ini.

3. Abdul Jawat Nur, SS. M.Hum. selaku dosen pembimbing akademik yang telah membantu dan mendorong penulis belajar selama kuliah.

4. Dra. Hindun, M.Hum. selaku dosen pembimbing skripsi yang telah berkenan menyetujui dan mengarahkan penulis dengan sabar selama penyusunan skripsi ini.

5. Murabbi Ruhina al-Magfurlah KH Asyhari Marzuqi, al-Magfurlah KH Agus Mansur, Ibu Nyai Barakah Asyhari, dan Kyai Agus Muslim Nawawi, yang telah menempa dan menguatkan ruh penulis, juga kepada asatidz PP Nurul Ummah Kota Gede Yogyakarta. 
6. Segenap dosen Universitas Gadjah Mada khususnya dosen-dosen di Jurusan Satra Asia Barat yang telah mendidik penulis selama kuliah di Fakultas Ilmu Budaya UGM, Yogyakarta.

7. Staf dan karyawan perpustakaan dan tata usaha Fakultas Ilmu Budaya fakultas Ilmu Budaya UGM atas bantuan dan kerjasama yang diberikan.

8. Bapak penulis yang memberikan amanah kepada penulis, teladan dan cermin penulis. Ibu penulis yang berlimpah kasih sayang. Semoga Allah senantiasa memberikan rahmat-Nya kepada Engkau berdua.

9. Saudara penulis: Ultuf Diana Ruhma (mama Rahul), Tri my Luchis Manfaati, Satria Muwaffa, dan Asif Fitratun Naja, sebagai penyemangat utama bagi penulis berlari mengejar cita-cita.

10. Keluarga besar penulis di Blitar, Sidoarjo, dan Yogya, yang bersama-sama penulis mengarungi lautan ilmu tak bertepi Sang Pencipta.

11. Teman-teman angkatan: Lam Alif, Arif Budiman, Nur Muttaqien, Ahmad Fauzi, Irfan Zaki, Yulia Ramayanti, Ratna Sari Budiaty, Ahmad Rohadi, Ghulam Misbah, Hidayatun Nasihah, Hanan Khunaefi, Asep Saefudin S, Siti Aminah, Juniarti Mahmudah, Silviana Nur F, Mustamin, Kenyo M, Nurmin S, Danang Susilo, Yuhaeni Nisrina L, Aji Mahendra A, Yusik Wazan, Aminah, Ratna M, M Arif Maulana, Higa D Maitri, Yonki P, Andri, Wibowo, Rahmat A, S Aisyah, R Mufida, Kuat P, Yudani P, Jauharul U, Bahrul Ilmi, teman-teman D3, adik angkatan, dan kakak angkatan, (aku tak ada tanpa kalian).

12. Warga Nurul Ummah, khususnya kamar A2, dan teman debatku Ahmad Farid Z, terimakasih atas segala partisipasi. 
13. Teman-teman kuliah kerja nyata; Renta Dwi A, Novitri Hastuti, Novi Tugaswati, Budi Darmanto, Ifana Agustina, P Herry Setyono, kelompok Karanggede A, juga keluarga Sempulur (semoga bahagia selalu)

14. Teman-teman 3 Bahasa, tak lupa Farid M, Miftahul Ulum, Hendik M dan $M$ Hanif (persahabatan sesuatu yang sangat mahal).

15. Semua pihak yang tak mungkin disebutkan satu persatu.

Penulis menyadari sepenuhnya bahwa penyusunan skripsi ini masih jauh dari kesempunaan. Oleh karena itu, saran dan kritik dari pembaca yang bersifat membangun sangat penulis harapkan demi penyempurnaan skripsi ini. Semoga skripsi ini bermanfaat dan dapat memberikan sumbangan bagi perkembangan keilmuan khususnya dalam bidang sastra.

\section{DAFTAR ISI}

HALAMAN JUDUL .................................................................................. i 
HALAMAN PENGESAHAN.......................................................................... ii

HALAMAN PERNYATAAN.......................................................................... iii

HALAMAN MOTTO dan PESEMBAHAN............................................................ iv

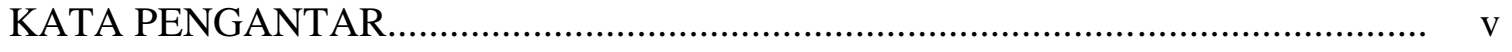

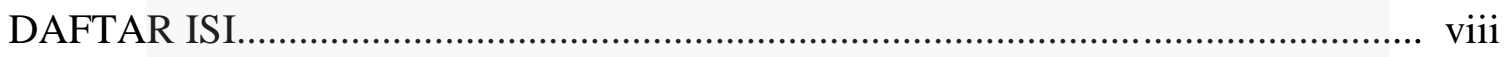

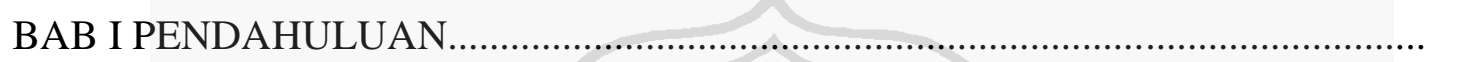

1.1 Latar Belakang Masalah....................................................................... 1

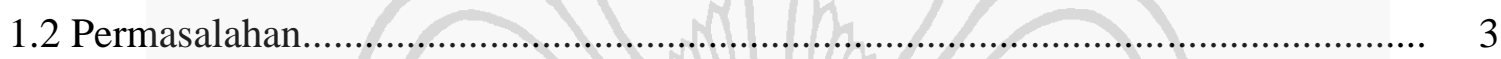

1.3 Tujuan Penelitian.................................................................................... 3

1.4 Tinjauan pustaka................................................................................

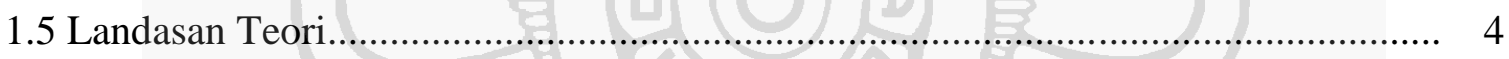

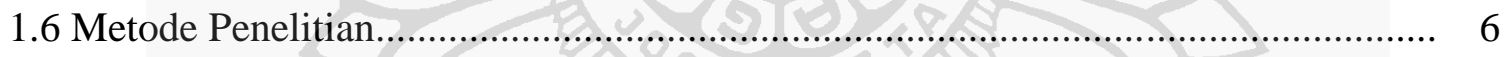

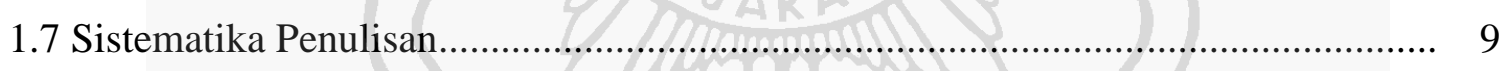

1.8 Pedoman Translliterasi Arab-Latin................................................................... 9

BAB II RIWAYAT HIDUP IMAM ALI IBN ABI TALIB DAN PUISINYA, AZZAINABIYYAH

2.1 Riwayat Hidup Imam Ali Ibn Abi Talib......................................................... 13

2.2 Puisi az-Zainabiyyah dan Terjemahannya........................................................ 17

BAB III ANALISIS SEMIOTIK PUISI AZ-ZAINABIYYAH IMAM ALI IBN ABI TALIB

(Pembacaan Heuristik dan Pembacaan Hermeneutik)................................................ 30

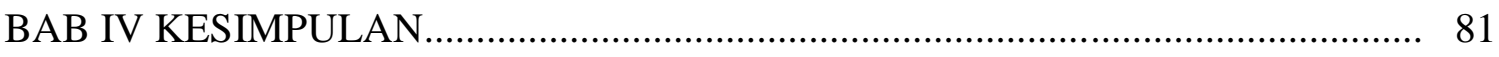

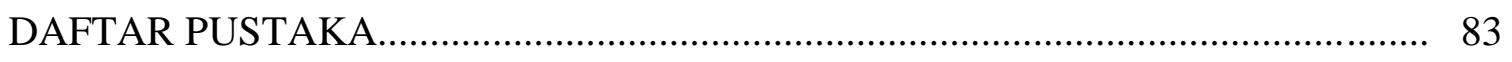

RINGKASAN SKRIPSI DALAM BAHASA ARAB 


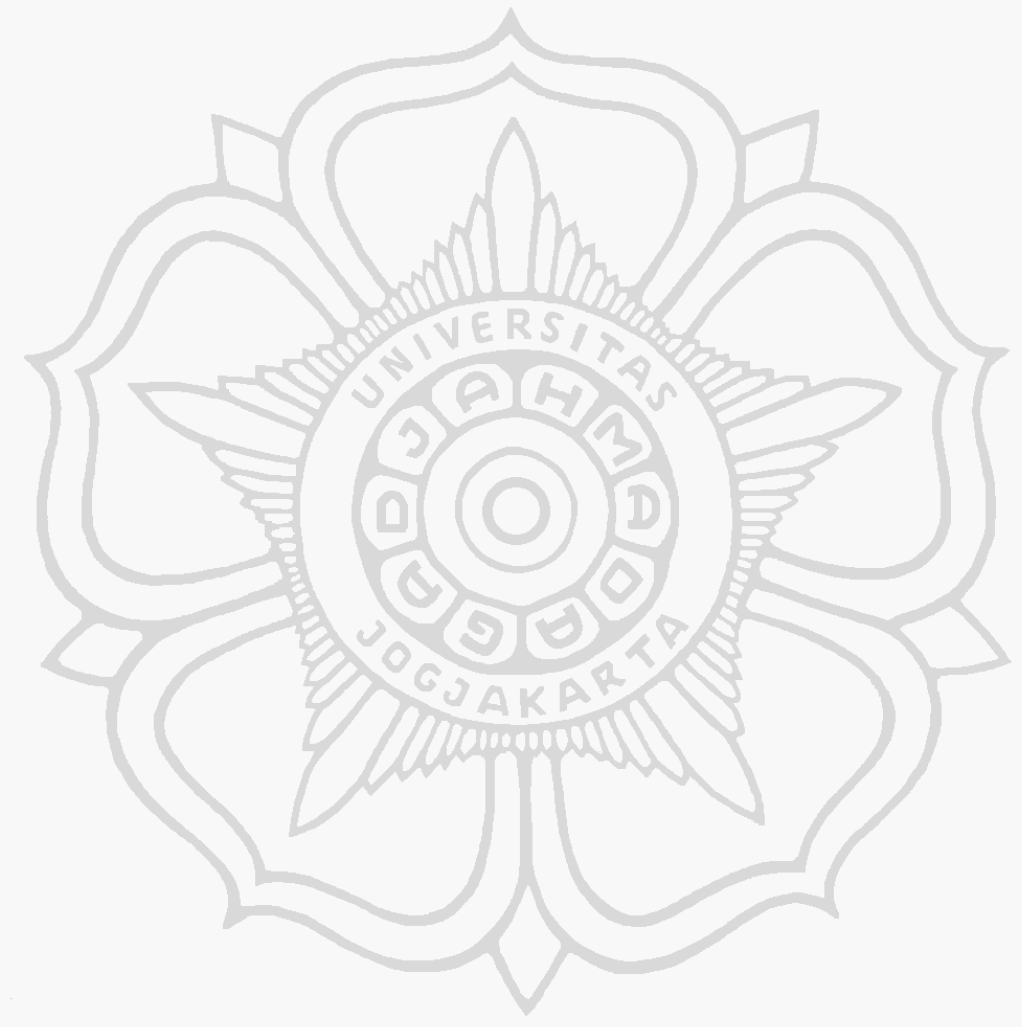




\section{BAB I}

\section{PENDAHULUAN}

\subsection{Latar belakang}

Bahasa Arab merupakan salah satu bahasa pemilik literatur sastra paling kaya di dunia. Jika dirunut, sejarah kesusastraan Arab telah melalui masa lebih dari 1500 tahun dan merupakan salah satu karya yang memiliki konstribusi penting pada perkembangan literatur sastra di seluruh dunia (Bakalla, 1984: 113).

Bagi masyarakat Arab, cabang seni yang paling dikenal adalah kesusastraan (Abdurrahman, 2002:313) sehingga kesusastraan merupakan inti dari seluruh seni, cermin dengan pantulan paling sempurna dari sendi-sendi kehidupan masyarakat Arab, baik kehidupan spiritual, politik, maupun hal-hal lain di luar keduanya (Zaidan:200-201 dalam Maryam, 2002:74).

Karya sastra Arab dipilah-pilah dalam beberapa kelompok berdasar periode tertentu. Salah satu pembagian yang paling dikenal adalah pengelompokan karya-karya tersebut ke dalam beberapa periode yang meliputi masa Jahiliyah, masa permulaan Islam, masa pemerintahan Umawi, masa pemerintahan Abbasiyah, masa pemerintahan Turki (Mamluk), serta masa modern yang masing-masing memiliki karakteristik tersendiri (Bakalla, 1984:114).

Pada masa permulaan Islam, para pengamat sastra pada umumnya menyatakan ada dua pendapat tentang perkembangan sastra, khususnya pada masa pemerintahan al-Khulafa ar-Rasyidun sebagai berikut. Pertama adalah stagnasi, disebabkan perhatian masyarakat lebih kepada bahasa al-Qur'an sehingga sastra kurang berkembang. Kedua, Al-Qur'an sebagai sumber inspirasi untuk kegiatan 
sastra karena dalam berdakwah diperlukan bahasa yang indah, sedangkan pengaruh Qur'an dan Hadis tidak bisa dilepaskan karena keduanya menjadi sumber pokok ajaran Islam (Zayyad:104-105 dalam Maryam, 2002:74).

Prosa tertuang dalam dua bentuk, yaitu khitabah (bahasa pidato) dan kitabah (karya sastra tertulis). Khitabah menjadi sarana paling efektif untuk berdakwah yang kesempurnaannya disebabkan pengaruh al-Qur'an. Roh khitabah adalah Rasul dan para khalifah, mereka adalah pemimpin yang sekaligus sastrawan, dan mereka sangat balig dan fasih dalam berkhotbah. Ahli pidato yang sangat terkenal adalah Ali ibn Abi Talib, khutbahnya dikumpulkan dalam kitab Nahj al Balagah. Adapun kitabah tidak mengalami kemajuan sepesat khitabah meskipun di dalamnya banyak didapatkan nilai-nilai sastra (Maryam, 2002:74).

Secara khusus dijelaskan bahwa puisi pada masa pemerintahan alKhulafa ar-Rasyidun tersebut tidak jauh berbeda dari puisi pada masa Rasul yang juga tidak jauh berbeda dengan masa sebelumnya (Jahiliyyah). Maksudnya bahwa puisi kurang berkembang karena lebih memperhatikan al-Qur'an. Akan tetapi, tidak berarti bahwa puisi tidak ada sama sekali pada masa itu, terbukti Imam Ali ibn Abi Talib menyusun banyak puisi. Di antara puisinya dibukukan dalam "Diwan Amir al-Mukminin wa Sayyid al-Bulagai wa al-Mutakallimin Al Imam Ali Ibn Abi Talib Alaihi as-Salam“ yang diedit oleh Abdul Aziz Karim.

Diwan tersebut berisi pesan-pesan kepada pembacanya. Salah satu tema puisi yang menarik untuk dikaji adalah puisi az-Zainabiyyah yang berisi nasihat kepada dirinya sendiri yang dikaitkan dengan putrinya, Zainab binti Ali. 
Tiap-tiap bait puisi tersebut berisi pengetahuan dan nasihat yang berguna bagi pembaca. Oleh karena itu, penelitian ini akan mengkaji makna puisi azZainabiyyah Imam Ali yang bertema nasihat kepada dirinya sendiri yang dikaitkan dengan putrinya, Zainab binti Ali.

\subsection{Permasalahan}

Berdasar latar belakang di atas, permasalahan yang akan dijawab dalam penelitian ini adalah apa makna yang terkandung dalam puisi az-Zainabiyyah Imam Ali dalam buku "Diwan Amir al-Mukminin wa Sayyid al-Bulagai wa alMutakallimin Al Imam Ali Ibn Abi Talib Alaihi as-Salam“ yang diedit oleh Abdul Aziz Karim.

\subsection{Tujuan penelitian}

Penelitian puisi az-Zainabiyyah Imam Ali ini mempunyai dua tujuan, tujuan praktis dan tujuan teoretis. Secara praktis, penelitian ini bertujuan untuk mengungkapkan makna yang terkandung di dalamnya.

Adapun secara teoretis penelitian ini mengungkapkan bahwa kehidupan di akhirat yang kekal lebih utama daripada kehidupan di dunia yang fana. Oleh karena itu, selayaknya manusia mempersiapkan dan membekali diri sebaik mungkin untuk menyongsong kehidupan akhirat. 


\subsection{Tinjauan Pustaka}

Sejauh pengamatan penulis, penelitian yang menyangkut bidang semiotik pada puisi az-Zainabiyyah dalam buku "Diwan Amir al-Mukminin wa Sayyid al-Bulagai wa al-Mutakallimin Al Imam Ali Ibn Abi Talib Alaihi asSalam“ yang diedit oleh Abdul Aziz Karim, belum pernah dilakukan atau diteliti sebelumnya oleh mahasiswa Jurusan Sastra Asia Barat Fakultas Ilmu Budaya UGM. Oleh karena itu, puisi tersebut perlu diteliti lebih lanjut.

\subsection{Landasan Teori}

Manusia sebagai homo significans, dengan karyanya akan memberi makna kepada dunia nyata atas dasar pengetahuannya. Pemberian makna dilakukan dengan cara mereka dan hasil karyanya berupa tanda (Chamamah Soeratno dalam Sangidu, 2004:18).

Sebagai tanda, karya sastra merupakan dunia dalam kata yang dapat dipandang sebagai sarana komunikasi antara pembaca dan pengarangnya. Karya dapat dipandang sebagai gejala semiotik (Teeuw dalam Sangidu, 2004:18).

Semiotik merupakan suatu disiplin yang meneliti semua bentuk komunikasi selama komunikasi itu dilaksanakan dengan menggunakan tanda yang didasarkan pada sistem-sistem tanda atau kode-kode (Segers dalam Sangidu, 2004:18).

Bahasa sebagai medium karya sastra sudah merupakan sistem semiotik atau ketandaan, yaitu sistem ketandaan yang mempunyai arti. Medium bahasa 
yang dipakai bukan bahasa yang bebas, melainkan sesuai dengan konvensi bahasa yang berlaku (Pradopo, 2005:120).

Pertama kali yang penting dalam lapangan semiotik, lapangan sistem tanda, adalah pengertian tanda itu sendiri. Dalam pengertian tanda ada dua prinsip, yaitu penanda (signifier) atau yang menandai, yang merupakan bentuk tanda, dan petanda (signified) atau yang ditandai, yang merupakan arti tanda (Pradopo, 2005:121).

Bahasa yang merupakan sistem tanda yang kemudian dalam karya sastra menjadi mediumnya itu adalah sistem tanda tingkat pertama. Dalam ilmu tandatanda atau semiotik, arti bahasa sebagai sistem tanda tingkat pertama itu disebut meaning (arti). Karya sastra itu juga merupakan sistem tanda yang berdasarkan konvensi masyarakat (sastra). Karena sastra (karya sastra) merupakan sistem tanda yang lebih tinggi kedudukannya dari bahasa, maka disebut sistem semiotik tingkat kedua. Bahasa tertentu itu mempunyai konvesi tertentu pula, dalam sastra konvensi bahasa itu disesuaikan dengan konvensi sastra. Dalam karya sastra, arti kata-kata (bahasa) ditentukan oleh konvensi sastra. Dengan demikian, timbullah arti baru yaitu arti sastra itu. Jadi arti sastra itu merupakan arti dari arti (meaning of meaning). Untuk membedakan dari arti bahasa, arti sastra disebut makna (significance) (Pradopo, 2005:120).

Makna sajak itu bukan semata-mata arti bahasanya, melainkan arti bahasa dan suasana, perasaan, intensitas arti, arti tambahan (konotasi), daya liris, pengertian yang ditimbulkan tanda-tanda kebahasaan atau tanda-tanda lain yang 
ditimbulkan oleh konvensi sastra, misalnya tipografi, enjambement, sajak, baris sajak, ulangan, dan yang lainnya.

Meskipun sastra itu dalam sistem semiotik tingkatannya lebih tinggi daripada bahasa, namun sastra tidak dapat lepas pula dari sistem bahasa; dalam arti, sastra tidak dapat lepas sama sekali dari sistem bahasa atau konvensi bahasa. Hal ini disebabkan oleh apa yang telah dikemukakan, yaitu bahasa itu sudah merupakan sistem tanda yang mempunyai arti berdasarkan konvensi tertentu. Sastrawan dalam membentuk sistem dan maknanya dalam karya sastranya harus juga mempertimbangkan juga konvensi bahasanya sebab apabila ia sama sekali meninggalkannya, maka karyanya tidak dapat dimengerti dan dipahami oleh pembaca sebab sudah berada di luar perjanjian yang telah disepakati secara konvensional (Pradopo, 2005:120-123).

Dengan demikian, studi sastra yang bersifat semiotik adalah usaha untuk menganalisis karya sastra, khususnya puisi sebagai suatu sistem tanda-tanda dan menentukan konvensi-konvensi apa yang memungkinkan karya sastra tersebut mempunyai makna. Dalam kaitannya dengan kerangka teori semiotik di atas, maka puisi az-Zainabiyyah dapat pula dipandang sebagai gejala semiotik.

\subsection{Metode Penelitian}

Berdasar landasan teori di atas, metode penelitian yang dipakai dalam penelitian ini adalah metode semiotik. Riffatere dalam bukunya semioitics of poetry (1978) mengungkapkan bahwasanya ada empat hal pokok untuk memproduksi makna puisi yaitu: ketaklangsungan ekspresi, pembacaan heuristik 
dan retroaktif atau hermeneutik, matrix atau kata kunci (key word), dan hypogram (berkenaan dengan prinsip intertekstual) (Pradopo, 2005:281).

Dikemukakan Riffatere (1978:1-2) bahwa puisi itu merupakan ekspresi tidak langsung. Ketidaklangsungan ekspresi itu disebabkan oleh tiga hal: penggantian arti (displacing of meaning), penyimpangan arti (distorting of meaning), dan penciptaan arti (creating of meaning) (Pradopo, 2005:282).

Hal pokok kedua adalah pembacaan semiotik yang terdiri atas pembacaan heuristik dan retroaktif atau hermeneutik. Dalam pembacaan heuristik puisi dibaca berdasarkan konvensi bahasa atau sistem bahasa sesuai dengan kedudukan bahasa sebagai sistem semiotik tingkat tingkat pertama. Sajak dibaca secara linier, menurut struktur normatif bahasa. Pada umumnya, bahasa puisi menyimpang dari penggunaan bahasa biasa (normatif). Bahasa puisi merupakan deotomatisasi atau defamiliarisasi: ketidakotomatisan atau ketidakbiasaan. Oleh karena itu, dalam pembacaan heuristik semua yang tidak biasa dibuat biasa atau dinaturalisasikan sesuai dengan sistem bahasa normatif. Bilamana perlu, kata-kata diberi awalan atau akhiran, disisipkan kata-kata supaya menjadi jelas (Pradopo, 2005:295-296).

Pembacaan retroaktif atau hermeneutik adalah pembacaan ulang dari awal sampai akhir dengan penafsiran. Pembacaan ini adalah pemberian makna berdasarkan konvensi sastra (puisi). Puisi menyatakan sesuatu gagasan secara tidak langsung, dengan kiasan, ambiguitas, kontradiksi, dan pengorganisasian ruang teks, seperti telah dijelaskan di awal (Pradopo, 2005:297). 
Hal pokok ketiga adalah matrix, Pradopo (2005:299) mengungkapkan bahwa untuk "membuka" sajak supaya mudah dipahami, dalam konkretisasi puisi, haruslah dicari matrixnya, yaitu kata yang menjadi kunci penafsiran sajak yang dikonkretisasikan.

Adapun hal keempat adalah hypogram. Riffatere (1978:23) mengungkapkan bahwa hipogram adalah teks yang menjadi latar penciptan teks lain. Seringkali sebuah sajak baru mendapatkan makna hakikinya setelah dikontraskan (disejajarkan) dengan sajak yang menjadi hipogramnya. Hubungan antar teks ini disebut juga dengan prinsip intertekstualitas (Pradopo, 2005:300).

Meskipun dalam penelitian semiotik terdapat empat hal pokok yang dapat dilampaui, tetapi dalam penelitian ini penulis hanya menggunakan pembacaan semiotis yang terdiri atas pembacaan heuristik dan hermeneutik. Pemilihan ini disebabkan kedua pembacaan tersebut sudah mencakup tiga hal pokok lainnya.

Puisi az-Zainabiyyah Imam Ali, dalam pembacaaan heuristik dibaca berdasarkan konvensi bahasa atau sistem bahasa sesuai dengan kedudukan bahasa sebagai sistem semiotik tingkat pertama. Puisi dibaca secara linier menurut struktur normatif bahasa. Karena puisi ini ditulis berdasar konvensi bahasa Arab, maka untuk membacanya harus dinaturalisasikan dan diterangkan arti yang dimaksud melalui pencarian arti dalam kamus atau yang telah ditulis dalam cataan kaki yang terdapat dalam redaksi buku lain yaitu buku Diwan Im. Ali Ibn Abi Talib yang diedit oleh Dr. Yusuf Farhat, dan diterbitkan oleh Dar al-Kutub. Begitu juga sisipan kata ditulis dalam tanda kurung supaya hubungan kalimat- 
kalimat puisi menjadi jelas. Penelitian dilanjutkan dengan pembacaan retroaktif atau hermeneutik yaitu pembacaan ulang puisi dari awal sampai akhir dengan penafsiran.

\subsection{Sistematika Penulisan}

Penulisan ini terdiri atas empat bab. Bab pertama berisi pendahuluan yang memuat latar belakang, permasalahan, tujuan penelitian, tinjauan pustaka, landasan teori, metode penelitian, sistematika penulisan dan pedoman transliterasi arab- latin. Bab kedua berisi riwayat hidup Imam Ali Ibn Abi Talib R.a. dan puisinya az-Zainabiyyah beserta terjemahannya. Bab ketiga berisi analisis semiotik puisi az-Zainabiyyah Imam Ali R.a. Bab keempat merupakan kesimpulan dari keseluruhan penjelasan yang sudah diterangkan, terutama dalam bab ketiga.

\subsection{Pedoman Transliterasi Arab- Latin}

Penulisan transliterasi Arab-Latin dalam penelitian ini menggunakan pedoman transliterasi dari keputusan bersama Menteri Agama RI dan Menteri pendidikan dan Kebudayaan RI no. 158 tahun 1987 dan no. 0543 b/U/1987.

\section{Konsonan}

Konsonan bahasa Arab dilambangkan dengan huruf hijaiyah/ disebut huruf Arab

\begin{tabular}{|c|c|c|c|c|}
\hline No & $\begin{array}{c}\text { Huruf } \\
\text { Arab }\end{array}$ & Nama & Huruf latin & nama \\
\hline 1 & & Alif & $\begin{array}{c}\text { Tdk } \\
\text { dilambangkan }\end{array}$ & Tidak dilambangkan \\
\hline 2 & & $B a$ & $\mathrm{~B}$ & $\mathrm{Be}$ \\
\hline 3 & & $\mathrm{Ta}$ & $\mathrm{T}$ & $\mathrm{Te}$ \\
\hline 4 & & $\mathrm{Sa}$ & $\mathrm{S}$ & Es (dengan titik di atas) \\
\hline
\end{tabular}




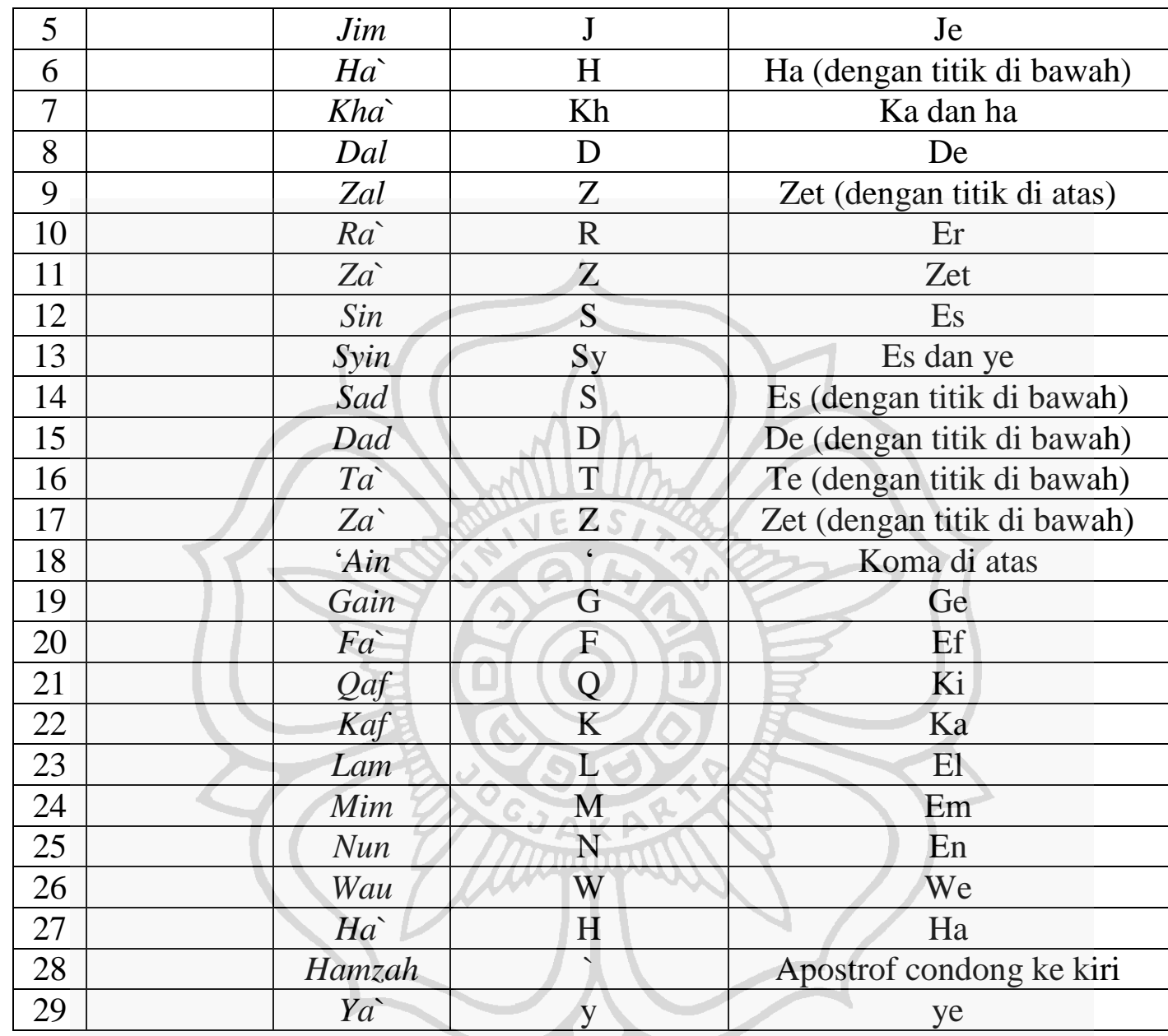

2. Vokal

\begin{tabular}{|c|c|c|c|}
\hline No & Vokal Pendek & Vokal Panjang & Diftong \\
\hline 1 & $\ldots: a$ & I...: : a & ئ... : ai \\
\hline 2 & $\ldots: \mathrm{i}$ & ي : i & $9 . . . \stackrel{8}{:} a u$ \\
\hline 3 & $\ldots \stackrel{8}{.}: u$ & و... : u & \\
\hline
\end{tabular}

\section{Ta`Marbutah}

Transliterasi untuk ta `marbutah ada dua, yaitu:

a. Ta` marbutah hidup atau mendapat harakat fathah, kasrah, atau dammah, transliterasinya adalah /t/ 
b. Ta` marbutah mati atau mendapat harakat sukun, transliterasinya adalah $/ \mathrm{h} /$.

Jika ta` marbutah terdapat pada kata yang terakhir, dan diikuti oleh kata yang menggunakan kata sandang al serta kedua kata itu terpisah, maka $t a{ }^{`}$ marbutah itu di transliterasikan dengan /h/. Contoh:

$$
\begin{aligned}
\text { - al-Madinah al-Munawwarah } \\
\text { : al-Madinatul-Munawwarah }
\end{aligned}
$$

\section{Syaddah}

Tanda syaddah dilambangkan dengan huruf yang sama dengan huruf yang diberi tanda syaddah tersebut. Contoh:

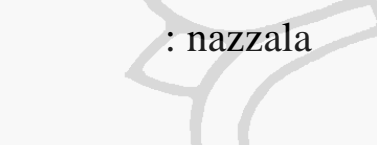

\section{Kata sandang}

Transliterasi kata sandang dibedakan atas kata sandang yang diikuti oleh huruf syamsiyah dan kata sandang yang diikuti oleh huruf qamariyah.

a. kata sandang yang diikuti oleh huruf syamsiyah ditransliterasikan sesuai dengan bunyinya, yaitu huruf /1/ diganti dengan huruf yang sama dengan huruf yang langsung mengikuti kata sandang tersebut. Contoh:

- $\quad$ : asy-syamsu

b. kata sandang yang diikuti huruf qamariyah ditransliterasikan sesuai dengan bunyinya, yaitu huruf /1/ ditulis terpisah dari kata yang mengikutinya. Contoh:

: al-qamaru

\section{Hamzah}

Hamzah ditransliterasikan dengan apostrof jika terletak ditengah dan akhir kata. Bila terletak diawal kata, ia tidak dilambangkan karena dalam tulisan Arab berupa alif. Contoh: 


$$
\begin{gathered}
\text { : inna } \\
\text { يأخذ : ya`khuzu } \\
\text { : qara`a }
\end{gathered}
$$

\section{Penulisan Kata}

Pada dasarnya setiap kata ditulis terpisah, tetapi untuk kata-kata tertentu yang penulisannya dalam huruf Arab sudah lazim dirangkaikan dengan kata lain kerena ada huruf atau harakat yang dihilangkan, maka transliterasinya dirangkaikan dengan kata lain yang mengikutinya. Contoh:

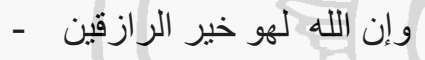

Wa innallaha lahuwa khair ar-raziqin

$>$ Wa innallaha lahuwa khairur-raziqin

\section{Huruf Kapital}

Meskipun dalam sistem tulisan Arab tidak dikenal huruf kapital, tetapi dalam transliterasinya huruf kapital digunakan dengan ketentuan Ejaan Yang Disempurnakan (EYD). Contoh:

: Wa ma Muhammadun illa rasul 


\section{BAB II}

\section{RIWAYAT HIDUP IMAM ALI IBN ABI TALIB}

DAN PUISINYA, AZ-ZAINABIYYAH

\subsection{Riwayat hidup Imam Ali Ibn Abi Talib}

Nama lengkapnya Abul Hasan Ali Ibn Abi Talib Ibn ‘Abdil Mutallib Ibn Hasim. Ia berkebangsaaan Quraisy. Lahir di Makkah al-Mukarramah sekitar tahun 600 masehi (Farhat, 1995:7). Al-Hasyimi (1965:118) menyatakan bahwa Imam Ali lahir tiga puluh dua tahun setelah Nabi lahir.

Ayahnya wafat saat ia berusia enam tahun. Kemudian sepupunya, Muhammad, Rasulullah membawanya ke rumah, mengasuh dan mendidiknya. Ia tumbuh dewasa dengan asuhan cinta kasih Rasul. Ketika Rasul mulai mendakwahkan agama Islam, Imam Ali pun mengikutinya. Dia termasuk golongan orang laki-laki yang masuk Islam sejak dini (Farhat, 1995:7).

Ia orang yang besar hati, besar rasa ikhlasnya, kuat imannya, semangat juangnya dalam membela agama baru (Islam) terus mengalir, serta selalu mengharap keridloan sepupunya, Nabi Saw. Ia pernah menggantikan Nabi untuk tinggal di rumahnya tatkala warga Makkah mengepung dan menghalangi Nabi untuk bepergian. Ia juga selalu mendampingi Nabi di semua peperangan Islam, kecuali pada perang Tabuk. Keberanian dan ketetapan jiwanya tampak jelas di perang Badr, pada perang Uhud dimana ia dilumpuhkan dengan banyak luka, 
demikian pula pada perang Khandaq, dan Khaibar di mana ia pemegang panji pasukan (Farhat, 1995:7).

Pada tahun keenam hijriah Imam Ali memerangi qabilah Bani Sa'd yang merupakan golongan Yahudi di Fadak. Pada tahun kesepuluh hijriah ia berperang di negara Yaman, serta banyak lagi hal penting yang diwakilkan Nabi kepadanya. Ia melakukan semua itu atas dasar kecintaan dan semangat yang jarang dimiliki orang lain, yaitu mengharap ridlo Allah dan Nabi semata (Farhat, 1995:7).

Setelah Nabi wafat Abu Bakar dibaiat menjadi khalifah, setelahnya Umar Ibn Khattab. Kemudian pemerintahan berpindah kepada Usman Ibn Affan. Selama pemerintahan tersebut, para khalifah selalu mengikutsertakan Imam Ali, mereka juga selalu mengajaknya memusyawarahkan permasalahan-permasalahan sulit. Ialah yang mengisyaratkan agar Umar mengambil permulaan hijrah sebagai permulaan penanggalan Islam. Dia pula yang mengisyaratkan pengkodifikasian Al-Qur`an (Farhat, 1995:7).

Setelah terbunuhnya Usman, beberapa orang Muhajirin dan Ansar datang dan membaiatnya. Setelah lima hari dia baru menyetujuinya. Peristiwa itu terjadi pada hari jumat 5 Zulhijjah tahun $35 \mathrm{H} / 4$ Juni $656 \mathrm{M}$. Di sisi lain banyak pemuka Islam yang terus menentang, di antaranya para pembesar Quraisy dan Madinah. Sikap-sikap seperti inilah yang tidak disukai Imam Ali, dan yang lebih menyedihkan bahwasanya beberapa kerabat dekat mengucilkannya, seperti Aisyah, isteri Nabi dan orang-orang sukunya (Farhat, 1995:8).

Muawiyah Ibn Abi Sufyan, gubernur Syam secara terang-terangan menentang Imam Ali, dan para pemberontak berkumpul padanya sehingga ia 
membentuk sekte Usmaniyah (Farhat, 1995:7). Mereka dari golongan Umayyah yang marah atas terbunuhnya Usman, serta tidak puas dengan kurangnya peranan Imam Ali dalam mengusut kasus pembunuhan Usman. Dari perjalanan kasus tersebut muncullah fitnah (masalah) besar dalam umat Islam, serta perpecahan sehingga muncul dua golongan yang saling berperang beberapa waktu lamanya selain juga perseteruan antara Imam Ali dan Muawiyah tidak pernah stabil (AlHasyimi, 1965:118) Akhirnya salah seorang khawarij (golongan yang tidak patuh pada Ali), Abdullah Ibn Muljam membunuhnya di masjid Kufah. Kejadian ini terjadi pada 17 Ramadan tahun 40 hijriah. Berdasar pendapat yang paling sahih ia kemudian dikuburkan di Kufah (Farhat, 1995:9).

Wanita yang paling utama bagi Imam Ali adalah Fatimah alaihas salam, putri Rasul. Ia menikahinya tahun 623 M. Ia tidak menikahi orang lain selama hidupnya. Baru setelah Fatimah wafat, ia menikah dengan beberapa wanita yang tidak terkenal (Farhat, 1995:9). Dari pernikahannya dengan Fatimah, ia dikarunia dua putra dan dua putri. Imam Hasan dan Husain yang oleh Nabi disebut sebagai pemuda penghuni surga, juga Zainab sang srikandi Islam yang tak kenal menyerah terhadap kekuasaan dan kesewenangan Yazid ibn Muawiyah, penguasa pemerintahan yang merebut kekhalifahan dari tangan kakaknya, Imam Hasan. Serta Ummu Kulsum, Si bungsu yang terkenal dengan sebutan Zainab al-Wusta (Al-Husaini, 1997).

Imam Ali karramallahu wajhah orang terfasih setelah Nabi, paling banyak ilmunya, paling zuhud, dan sangat memperhatikan kebenaran. Ia pemimpin para khatib bangsa Arab setelah Rasul (Al-Hasyimi, 1965: 119). 
Sebagian besar prosanya tertuang dalam kitab nahj al-balagah. Orang-orang terus terbayang dan sering membahas khutbah, ucapan dan prosa Imam Ali. Oleh sebab itu, as-Syarif ar-Rida mulai mengumpulkan khutbah, nasihat dan suratsurat Imam Ali, kemudian menyusunnya menjadi kitab tersebut. Banyak sastrawan yang senang menghafal dan mendalami makna kitab tersebut (Farhat, 1995:9).

Puisi yang disandarkan kepada Imam Ali lebih banyak mengambil sisisisi keagamaan dan akhlak. Oleh karena itu, puisi-puisinya terkenal dan tersebar di setiap majlis belajar. Puisi-puisinya terhindar dari susunan kata yang sulit dan makna yang terlalu dalam, melainkan dapat diterima bagi setiap pembaca (Farhat, 1995:10).

Salah satu contoh redaksi pidato Imam Ali sebagai berikut, yaitu ketika berpidato di hadapan kaum Anbar (wilayah di pinggiran sungai Eufrat bagian Timur) ketika mereka telah diserang oleh Sufyan Ibn Auf (utusan Muawiyah Ibn Abi Sufyan yang berasal dari Bani Gamid) bersama pasukannya tanpa berani melawan hingga Gubernur Hasan Bakri (pegawai Imam Ali untuk wilayah Ambar) mati bersama banyak para penduduknya. Pidato ini diutarakannya untuk membakar semangat mereka agar kembali berjuang (al-Jarimi, 1961:17).

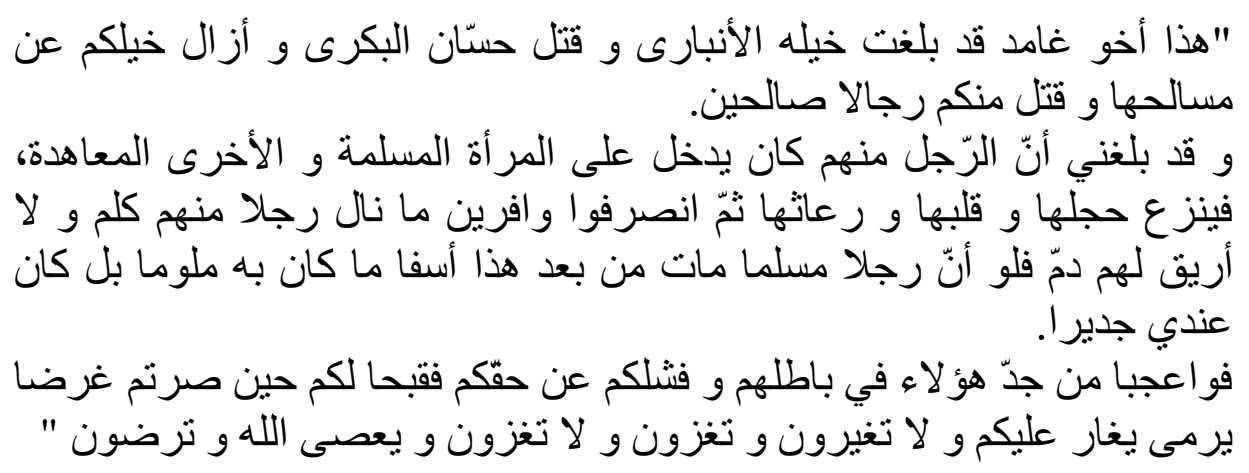


"Inilah seorang bani Gamid yang dengan kavalerinya mencapai negeri Ambar, membunuh Hasan Bakri, melarikan kuda-kuda kalian dari kandang serta membunuh banyak orang saleh kalian.

Kabar yang aku dengar, diantara mereka memasuki (menodai) wanita muslimah, juga wanita dzimmi (orang kafir yang dijaga umat Islam), bahkan mereka melucuti gelang kaki, gelang dan juga kalung. Setelah itu mereka pergi dengan utuh, tanpa luka sedikitpun, tanpa setetespun darah mereka mengalir, maka lelaki yang mati dengan mengenaskan setelahnya tidaklah memalukan, tidak tercela, bahkan lebih baik bagiku.

Sungguh mengherankan perihal kesungguhan mereka dalam kebatilan dan kelemahan kalian dalam kebenaran. Alangkah jeleknya saat kalian menjadi sasaran keserakahan musuh, mereka menyerbu dan kalian tidak membalas, kalian diperangi dan tidak berani melawan, dan Allah didzalimi dan kalian diam saja“.

Beberapa contoh kata hikmahnya seperti yang dikumpulkan Al-Hasyimi

(1965:119-120) sebagai berikut.

روى الثيخ خير هن مشهد الغلام. إذا قدرت على عدوّك فاجعل العفو عنه شكر ا

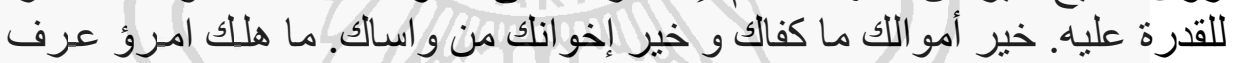

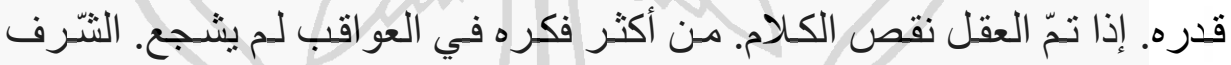

"Riwayat orang tua lebih baik dari persaksian anak-anak. Jika kamu mampu mengalahkan musuh, maka maafkan dia sebagai ungkapan syukur kemenanganmu atasnya. Sebaik-baik hartamu adalah yang membuatmu cukup dan sebaik-baik teman adalah yang menolongmu. Orang yang mengetahui kemampuannya tak akan celaka. Jika akal sempurna, ucapan berkurang. Orang yang terlalu menimbang akibat tak akan pernah menjadi berani. Kemulian adalah karena akal dan budi, bukan keturunan".

\subsection{Puisi az-Zainabiyyah Imam Ali dan terjemahannya}
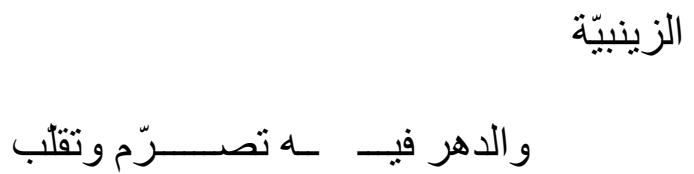

$$
\text { 1. صرمت حبالك بعد وصلك زين }
$$

(saramat hibalaka ba'da waslika zainabu waddahru fihi tasarrumun wa taqallubu) 
1. Zainab memutuskan hubunganmu, setelah rasa cintamu padanya. Adapun masa mencintainya telah terputus dan berubah.
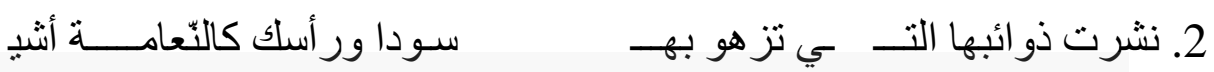

(nasyarat zawaibahallati tazhu biha sudan wa ra`suka kanna'amati asyyabu)

2. Jalinan rambutnya terurai menghiasinya, kehitam-hitaman, sedangkan kepalamu seperti pohon na'amah, beruban.<smiles>[Mg][Mg][Mg][Ca]</smiles>

(wastanfarat lamma ra`atka wa talama kanat tahinnu ila liqaka wa tarhabu)

3. Dia lari tatkala melihatmu meskipun ia selalu merindukanmu dan takut.

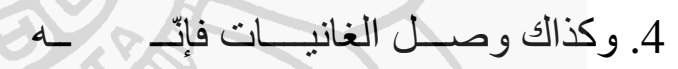

(wa kazaka waslul ganiyati fainnahu alun bibalqa'atin wa barqun khullabu)

4. Begitu juga kehadiran wanita cantik, sebenarnya itu fatamorgana di padang gersang dan kilat yang tak menimbulkan hujan.

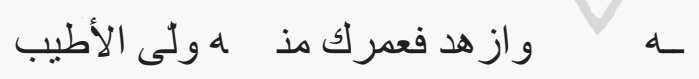

(fa da'issiba falaqad 'adaka zamanuhu fazhad fa umruka minhu wallal atyabu)

5. Tinggalkan masa kanak-kanak, masa itu telah menjauhimu, serta berzuhudlah, usia mudamu telah penuh keenakan.

$$
\text { وأتى المشيب فأين مذ ــه المهرب }
$$

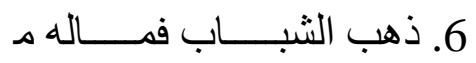

(zahabassyababu fa ma lahu min 'audatin wa atal masyibu fa aina minhul mahrabu)

6. Masa muda telah pergi, tidak akan kembali sedangkan masa tua telah datang, lalu ke mana akan pergi darinya. 


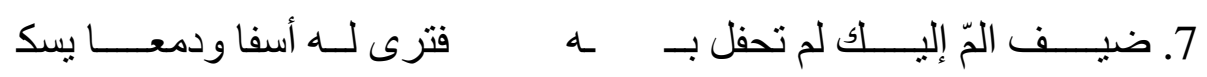

(daifun alamma ilaika lam tahfal bihi fa tara lahu asfan wa dam'an yaskubu)

7. Tamu mendatangimu, kamu tidak memperhatikannya, kemudian kamu akan melihatnya dengan menyesal dan bercucuran air mata.

$$
\text { ابك و ابكهــا يا مذنب }
$$

(da' anka ma qad fata fi zamanissiba wazkur zunubaka wabkiha ya muznibu)

8. Tinggalkan yang telah lewat di masa muda, ingatlah dosa-dosamu dan tangisilah, Wahai orang yang berdosa.

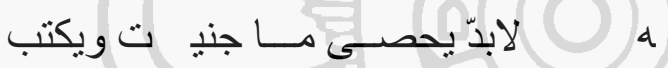

(wakhsya munaqasyatal hisabi fa innahu la budda yuhsa ma janaita wa yuktabu)

9. Khawatirkan ujian hari hisab, sesungguhnya apa yang kamu perbuat pasti akan dihitung dan dibukukan.

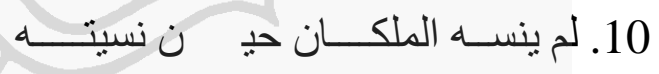

(lam yansahul malikani hina nasitahu bal asbatahu wa anta lahin tal'abu)

10. Dua malaikat itu tidak akan melupakan perbuatanmu, ketika kamu telah melupakannya, bahkan keduanya menetapkannya, padahal kamu lupa dan bermain-main.

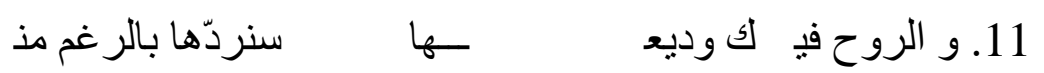

(warruhu fika wadi'atun udi'taha sanuradduha birragmi minka watuslabu)

11. Adapun roh pada dirimu adalah titipan yang dititipkan, akan dikembalikan/ ditarik dengan paksa dan dirampas darimu.

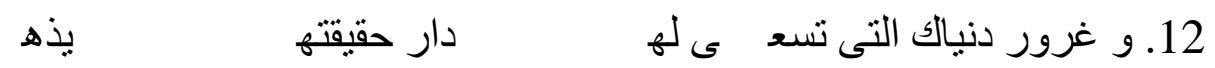


(wagururu dunyakal lati tas'a laha darun haqiqatuha mata'un yuzhabu)

12. Tipu daya dunia yang kamu usahakan adalah rumah yang hakikatnya adalah perhiasan yang akan pergi.

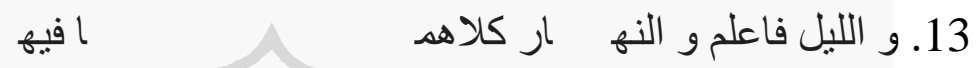

(wallailu fa'lam wannaharu kilahuma anfasuna fiha tu'addu wa tuhsabu)

13. Adapun malam dan siang, ketahuilah bahwa napas kita pada keduanya dipilah-pilah dan dihitung.

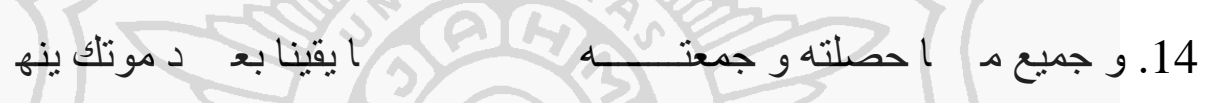

(wa jami'u ma hassaltahu wajama'tahu haqqan yaqinan ba'da mautika yunhabu)

14. Segala sesuatu yang kamu hasilkan dan kumpulkan benar-benar akan dirampas setelah kamu mati.

$$
\text { دار لا يدوم نعيمه مشيده }
$$

(tabban lidarin la yadumu na'imuha wa masyiduha 'amma qalilin yukhrabu)

15. Kecelakaan bagi negeri yang nikmat-nikmatnya dan bangunan-bangunannya tidak kekal, dan sedikit demi sedikit akan ditenggelamkan.

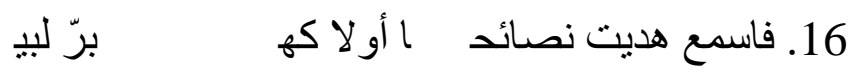

(fasma’ hudita nasaihan awlakaha barrun labibun aqilun muta`addibu)

16. Dengarlah, Kamu telah diberi petunjuk dengan nasihat yang disampaikan oleh orang yang baik, cerdas, berakal dan berpendidikan.

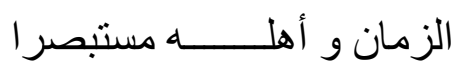

(sahibaz zamana wa ahlahu mustabsiran wara 'al umura bima ta 'ubu wata'qibu) 
17. Pergaulilah zaman dan penghuninya dengan membuka mata, lihatlah semua yang kau capai dan akibatnya kepadamu.

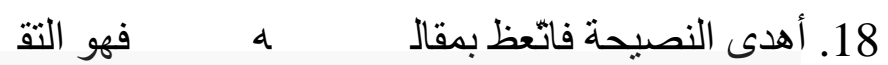

(ahdan nasihata fatta’iz bimaqalihi fa huwat taqiyyul lauzaiyyul `adrabu)

18. Dia memberikan nasihat, maka perhatikanlah ucapannya. Dia adalah orang bertaqwa, cerdas dan terampil/ terlatih.

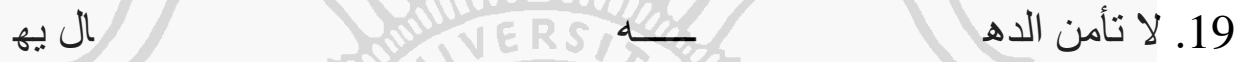

(la ta ’manid dahras sarufa fainnahu la zala qidaman lirrijali yuhazzibu)

19. Jangan diamkan masa yang telah berlalu. Sesungguhnya dari dulu waktu selalu mendidik orang- orang yang terpelajar.

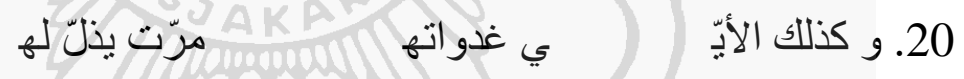

(wa kazalikal ayyamu fi gadwatiha marrat yuzillu lahal a'azzul anjabu)

20. Begitu juga dengan hari-hari, paginya berlalu. Orang yang mulia dan berkedudukan tinggi akan direndahkan karenanya.

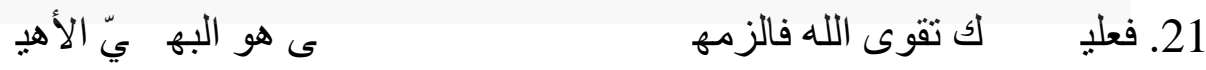

(fa 'alaika taqwallahi falzimha tafuz innat taqiyyu huwal bahiyyul ahyabu)

21. Kamu harus takut kepada Allah dan berpegang teguhlah niscaya kamu akan beruntung. Sungguh, taqwa itu rasa takut yang terbaik.

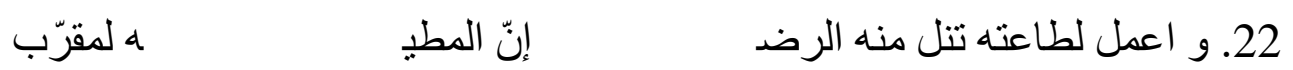

(wa'mal lita'atihi tanal minhurrida innal muti'a lirabbihi lamuqarrabu)

22. Berbuatlah untuk mentaati-Nya, niscaya kau peroleh ridla-Nya. Sesungguhnya orang yang taat pada Tuhannya akan didekatkan. 


$$
\text { و اليأس مدّ ا فات فه }
$$

(faqna' fafi ba'dil qana'ati rahatun walya`su mimma fata fahwal matlabu)

23. Qana'ahlah, di dalam qana'ah terdapat kelapangan. Adapun tahu hal-hal yang sudah dilalui dan dijalani itu yang dituntut.

$$
\text { 24. و إذا طمعت كسب }
$$

(wa iza tama'ta kusita sauba muzillatin falaqad kusi saubal muzillati asy'abu)

24. Jika kamu tamak, kau akan diberi pakaian kehianaan. Sungguh telah diberi baju kehinaan, yaitu beruban.

$$
\text { اءه خيان (D) فجمي عهن مك }
$$

(wa tawaqqa min gadrinnisa i khiyanatan fa jami’uhunna maka idun laka tunsabu)

25. Berhati-hatilah dari pengkhianatan wanita, mereka diadakan/diciptakan sebagai tipu daya bagimu.

$$
\text { كى حيات ك إنّهُ }
$$

(la ta`manil unsa hayataka innaha kal 'uf'uwani yura'u minhul anyabu)

26. Jangan percayai wanita sepanjang masamu. Sesungguhnya mereka seperti ular yang ditakuti bisanya/ taringnya.

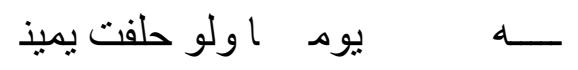

(la ta`manil unsa zamanaka kullahu yauman walau halafat yaminan takzibu)

27. Jangan percayai wanita seumur hidupmu, walaupun sehari. Mereka akan berdusta meskipun telah bersumpah.
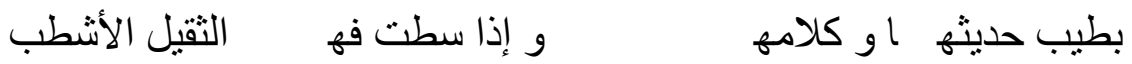
(tagri bi tibi hadisiha wa kalamiha waiza satat fa hiyassaqilul asytabu)

28. Mereka memikat dengan perkataan dan ucapan yang manis, kemudian tatkala menyerang mereka adalah pedang paling berat.

$$
\text { مid }
$$

$$
\text { 29. و الق عدوّك بالتحيّ }
$$

(walqi aduwwaka bittahiyyati la takun minhu zamanaka khaifan tataraqqabu)

29. Temui musuhmu dengan hormat. Jangan pernah takut selamanya sehingga kamu mendekatinya.

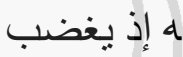

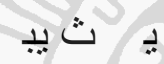$$
\text { 30. و واحذره يوم }
$$

(wahzarhu yauman in ata laka basiman fallaisu yabdu nabuhu iz yagdabu)

30. Perhatikanlah dia tatkala suatu hari mendatangimu dengan tersenyum. singa akan menampakkan taringnya lebih dahulu saat marah.

$$
\text { هذه }
$$

(innal haquda wa in taqadama 'ahdahu fal hiqdu baqin fissuduri mugayyabu)

31. Sesungguhnya pendendam itu meskipun telah berikrar, dendam akan tetap tinggal, tersembunyi di dadanya.

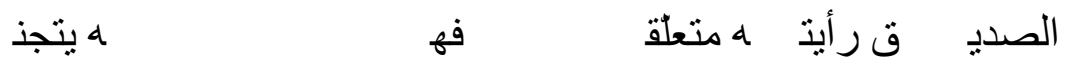

(wa izassadiqu ra`aytahu muta’alliqan fa huwal aduwwu wa haqquhu yutajannabu)

32. Jika temanmu kau lihat bergantung padamu, maka dia adalah musuh yang sebenarnya dijauhi.

$$
\text { ه يتلمه }
$$

(la khaira fi wuddimri in mutamalliqi hulwil lisani wa qalbuhu yatalahhabu) 
33. Tidak ada kebaikan mencintai seeorang yang mengutamakan mulut manis sedangkan hatinya bergejolak.

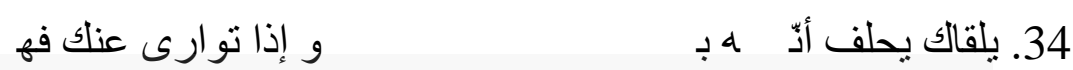

(yalqaka yahlifu annahu bika wasiqun wa iza tawara 'anka fahwal 'aqrabu)

34. Dia menemuimu, bersumpah setia padamu. Namun, ketika pergi darimu dia adalah kala.

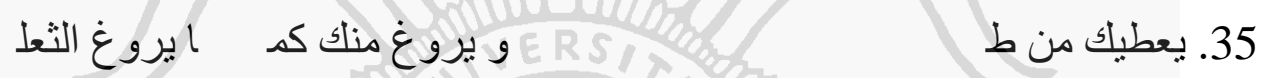

(yu'tika min tarfil lisani halawatan wa yarugu minka kama yarugus sa'labu)

35. Dari ujung bibirnya ia memberimu rasa manis, kemudian dia membujukmu sebagaimana musang.

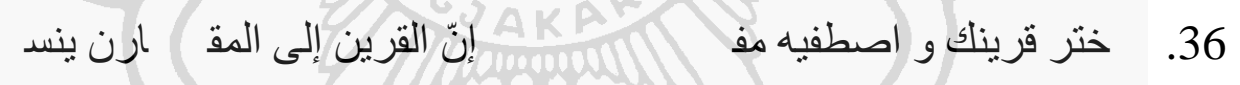

(wakhtar qarinaka wastafaihi mufakhiran innal qarina ilal maqarini yunsabu)

36. Pilihlah temanmu, ambillah yang terhormat. Sungguh, teman akan digolongkan berdasar temannya.

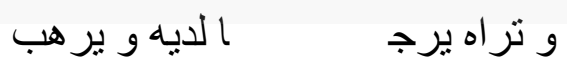

(innal ganiyya minar rijali mukarramun watarahu yurja ma ladaihi wa yurhabu)

37. Orang kaya dihormati orang-orang. Kamu melihatnya diharap-harapkan untuk dapat disanding dan dia juga ditakuti.

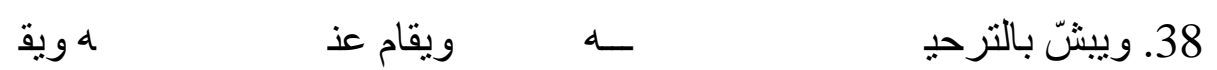

(wa yabussyu bittarhibi 'inda qudumihi wa yuqamu 'inda salamihi wa yuqarrabu)

38. Saat ia datang, ia disambut dengan senyum kelapangan serta disambut dan didekati atas keselamatannya. 


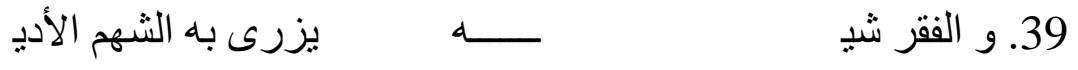

(wal faqru syainun lirrijali fa innahu yuzri bihissyahmul adibul ansabu)

39. Orang miskin adalah aib bagi orang-orang. Lantaran fakir, orang cerdas, beradab dan berketurunan baik direndahkan.

$$
\text { ك للأقارب كثه }
$$

(wahfid janahaka lil aqaribi kullihimi bi tazallulin wasmah lahum iz aznabu)

40. Rendahkan sayapmu terhadap seluruh kerabat dengan merendahkan diri, dan berilah mereka toleransi jika berbuat dosa.

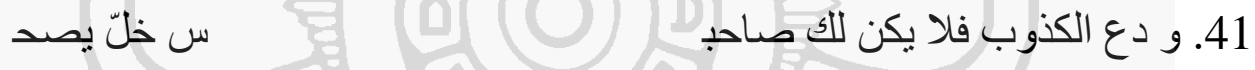

(wada'il kazuba fa la yakun laka sahiban innal kazuba labi sa khillun yushabu)

41. Jauhi pembohong, jangan sampai ia menjadi temanmu. Sungguh pembohong adalah seburuk-buruk teman untuk dipergauli.

$$
\text { ن رؤيالك لا يست }
$$

(wa zaril hasuda walau safa laka marratan ab’idhu 'an ru`yaka la yustajlabu)

42. Waspadalah terhadap pendengki, meskipun ia hanya sekali bersamamu. Jauhilah dia. Ia akan sulit hilang dari pandangan matamu.

(wa zinil kalama iza nataqta wala takun sarsaratan fi kulli nadin takhtubu)

43. Susunlah kata-katamu saat kamu berbicara. Jangan seperti mata air yang berlimpah di setiap seruanmu.

$$
\text { فالمرء يسلم باللسد ان و يعط }
$$

(wakhfiz lisanaka wahtariz min lafzihi fal mar’u yaslimu billisani wa yu’tabu) 
44. Jaga lisanmu. Perhatikan tiap kata-katanya. Seseorang akan selamat ataupun terjerumus karena lisannya.

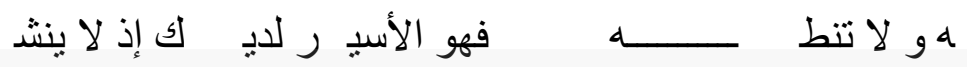

(wassirru faktumhu wa la tantiq bihi fa huwal asiru ladaika iz la yunsyabu)

45. Jagalah rahasia dan jangan membicarakanya. Hal itu seperti tawanan di sampingmu, meski tidak terlibat.

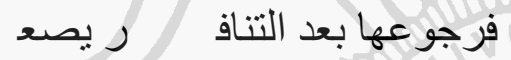

(wahris 'ala hifzil qulubi minal aza fa ruju'uha ba'dat tanafuri yas'ubu)

46. Bersungguhlah dalam menjaga hati dari penyakit karena mengembalikannya setelah berubah sangatlah sulit.

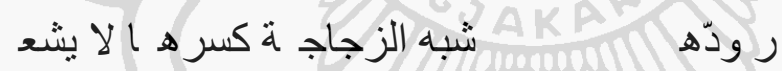

(innal quluba iza tanafara wadduha syibhuzzujajati kasruha la yusy`abu)

47. Sesungguhnya hati itu jika cintanya telah berubah menjadi benci, akan menyerupai kaca, pecahannya tak dapat disatukan.

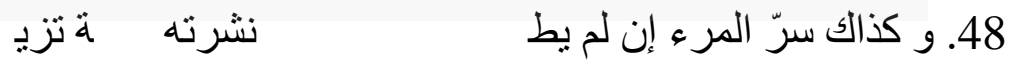

(wa kazaka sirrul mar ${ }^{i}$ in lam yatwihi nasyarathu alsinatun tazidu wa tukzabu)

48. Begitupula rahasia seseorang. Apabila dia tidak menyembunyikannya, maka mulut-mulut akan menyebarkanya, menambah dan mendustakannya.

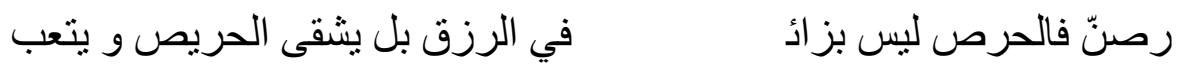

(la tahrasanna fal hirsu laisa bizaidin firrizqi bal yusyqil harisa wa yut'ibu)

49. Jangan tamak. Tamak tidak menambah rizki, bahkan mencelakakan dan menyusahkan. 


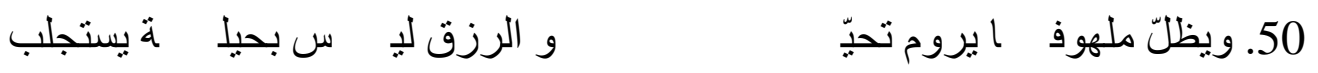

(wa yazillu malhufan yarumu tahayyulan warrizqu laisa bihilatin yustajlabu)

50. Orang tamak akan terus dibayangi khayalan, sedangkan rizki tidak diperoleh dengan berkhayal.

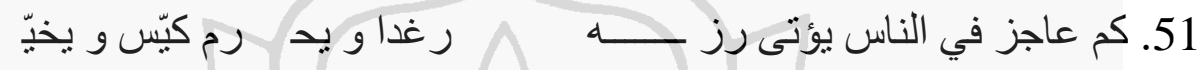

(kam ajizin fin nasi yu`ta rizqahu ragadan wa yuhramu kayyisun wa yukhayyabu)

51. Banyak orang lemah yang dilapangkan rizqinya, dan orang mampu (perlente) terhalang dan terkecewakan.

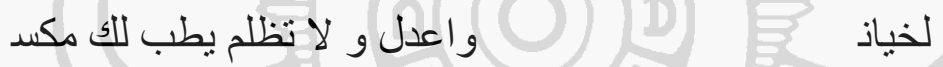

(addil amanata wal khiyanata fajtanib wa'dil wa la tazlim yatib laka maksabu)

52. Penuhilah amanat dan jauhi khianat. Berbuatlah adil jangan dzalim, niscaya usahamu akan beroleh kebajikan.

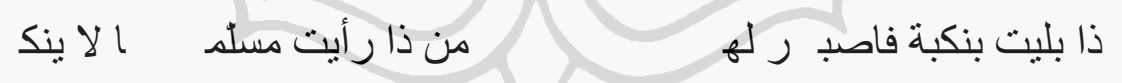

(wa iza bulita binukbatin fasbir laha man za ra`ayta musalliman la yunkabu)

53. Bersabarlah jika kau tertimpa bencana, ia juga menimpa orang yang kau anggap selamat.

$$
\text { 54. }
$$

(waiza asabaka fi zamanika syiddatun wa asabakal khatbul karihul as'abu fad'u llirabbika innahu adna liman yad'uhu min hablil waridi wa aqrabu) 
54, 55. Jika dalam hidupmu kau tertimpa kesulitan, juga hal-hal yang sulit dan yang kau benci, maka berdoalah kepada Tuhanmu. Sungguh Ia lebih dekat daripada urat leher bagi orang yang memanggil-Nya.

$$
\text { إنّ الكثير من الورى لا يصد }
$$

(kun mastata’ta 'anil anami bimanzilin innal kasira minal wara la yushabu)

56. Carilah tempat di hadapan orang-orang semampumu karena banyak orang tidak ditemani.

$$
\text { 57. و اجعل جليسك سيّدا تحظى م A مبر لبي }
$$

(waj'al jalisaka sayyidan tahza bihi habrun labibun 'aqilun muta 'addibu)

57. Anggaplah tamumu sebagai tuan yang kau hormati, sebagai pendeta, orang pandai, berakal, dan berpendidikan.

$$
\text { ل به }
$$

$$
\text { مظلاوم ســا صـائب }
$$

(wahzar minal mazlumi sahman sa'iban wa'lam bi 'anna du'a 'ahu la yuhjabu)

58. Waspadalah terhadap orang yang terdzalimi, yang banyak tertimpa musibah. Ketahuilah bahwa doanya tidak terhijab.

$$
\text { 60. 59. ف إذا رأي }
$$

(wa iza ra`aytar rizqa daqa bibaldatin wa khasyita fiha an yadiqal maksabu farhal fa ardullahi wasi'atul fada tulan wa 'irdan syarquha walmagribu)

59, 60. Jika kamu rasa rizki di suatu negeri terbatas (sempit), dan kamu takut kesempatan kerja didalamnya sempit, maka pergilah. Bumi Allah penuh kelapangan baik panjang, lebar, timur maupun baratnya. 


$$
\text { ع ما يب اع و يوهب }
$$$$
\text { إن قبلت نصيحت }
$$

(fa laqad nasahtuka in qabilta nasihati fannushu agla ma yuba'u wa yuhabu)

61. Aku sungguh telah menasihatimu (yang) jika kau terima, maka nasihat itu merupakan barang dagangan dan hadiah paling mahal.

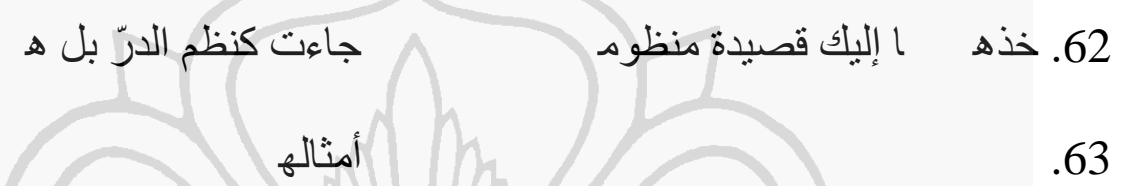

(khhuzha ilaika qasidatan manzumatan ja’at kanazmid durri bal hiya a'jabu hikamin wa adabin wa jullu mawa'izin amsaluha lizawil basa iri tuktabu)

62, 63. Jadikanlah itu qasidah berirama. Ia akan seperti untaian mutiara bahkan dia merupakan hikmah-hikmah dan adab paling mengagumkan. Juga pesan-pesan tertulis yang paling agung bagi orang-orang yang berhati nurani.

$$
\text { غ لو عظ قصيدة ولاكه }
$$

(fasgi liwa'zi qasidatin awlakaha taudal ulumissyamikhatil ahyabu)

64. Condonglah pada penasihat yang telah memberimu gunung ilmu dan kemuliaan tinggi.

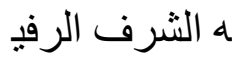

(a'ni aliyyan wabna 'ammi muhammadin man nalahus syarafur rafi'ul ansabu)

65. Yakni Ali putra paman Muhammad yang memperoleh kemuliaan nasab tinggi.

$$
\text { ق حصر ها لا يحسب }
$$

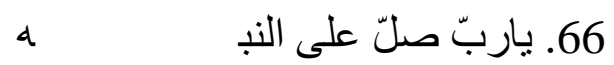

(ya rabbi salli 'alan nabiyyi wa alihi 'adadal khalaiqi hasruha la yuhsabu)

66. Ya Tuhan, tambahkanlah keselamatan kepada Nabi Muhammad beserta keluarganya sebanyak makhluk-Mu yang tak terhitung bilangannya. 


\section{BAB III}

\section{ANALISIS SEMIOTIK}

\section{PUISI AZ-ZAINABIYYAH IMAM ALI IBN ABI TALIB}

Konkretisasi makna puisi dapat diusahakan dengan pembacaan heuristik dan retroaktif atau hermeneutik. Adapun teknik pembacaannya dapat saja dilakukan secara simultan atau serentak tergantung kondisi karya sastra yang sedang atau akan diteliti. Artinya, pembacaan heuristik ataupun pembacaan hermeneutik dapat berjalan secara serentak atau bersama-sama (Sangidu, 2005:19).

Berdasar teknik di atas, puisi az-Zainabiyah Imam Ali yang terdiri dari enam puluh enam bait ini akan dibaca perbagian yang terdiri dari satu sampai lima bait secara heuristik, kemudian dilanjutkan dengan pembacaan secara hermeneutik.

Dalam pembacaan heuristik, puisi dibaca berdasarkan konvensi bahasa atau sistem bahasa sesuai dengan kedudukan bahasa sebagai sistem semiotik tingkat pertama. Puisi dibaca secara linier menurut struktur normatif bahasa. Bilamana perlu, kata-kata diberi awalan atau akhiran, disisipkan kata-kata supaya hubungan kalimat-kalimat puisi menjadi jelas (Pradopo, 2005:296).

Adapun dalam pembacaan hermeneutik, yaitu pembacaan dengan tafsir, puisi diberi makna berdasarkan konvensi sastra (puisi) ( Pradopo, 2005:297).

Pembacaan heuristik dan hemeneutik puisi az-Zainabiyah Imam Ali adalah sebagai berikut. 


\section{الزينبيّة}

1. Bait ke-1:

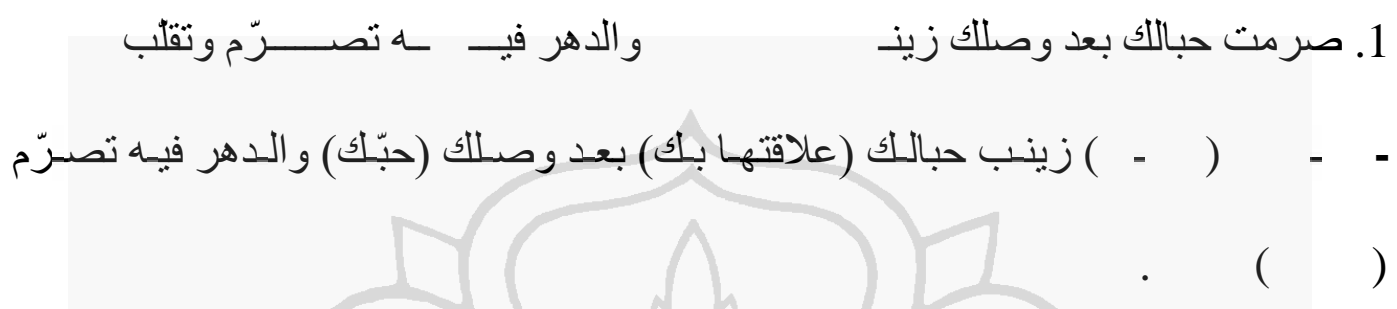

- Zainab telah memutus hubungannya denganmu setelah cintamu dan sayangmu kepadanya, sedangkan masa untuknya telah berhenti (terputus) dan berubah.

Bait pertama menyatakan bahwasanya $\mathrm{Si}$ Kamu sangat mencintai putrinya, Zainab, sampai ia tidak merasa bahwa waktu terus berlalu. Orang yang mencintai seseorang atau sesuatu kadang akan lupa waktu karena waktu menjadi terasa singkat. Si Kamu juga merasakan hal yang demikian, sampai ia sadar bahwa waktu terus berjalan. Sudah selayaknya ia tidak terlalu mementingkan diri untuk mencintai putrinya semata dan ia sadar waktu terus berubah. Berkaitan dengan waktu bahwasanya segala sesuatu di dunia ini terbatas, Allah berfirman dalam surat al-A'raf sebagai berikut.

Tiap-tiap umat mempunyai batas waktu;... (Q. S. Al-A'raf:34).

Adapun fitrah manusia adalah mencintai dunia dan seisinya yang memang diciptakan Allah untuk kepentingan manusia. Seperti firman Allah berikut.

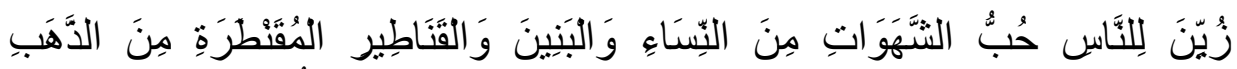

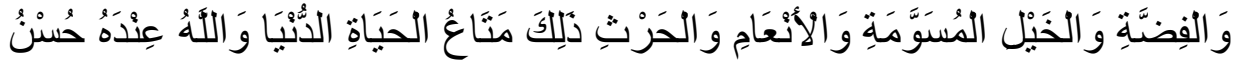

Dijadikan indah pada (pandangan) manusia kecintaan kepada apa-apa yang diingini, yaitu: wanita-wanita, anak-anak, harta yang banyak dari 
jenis emas, perak, kuda pilihan, binatang-binatang ternak dan sawah ladang. Itulah kesenangan hidup di dunia dan di sisi Allah-lah tempat kembali yang baik (surga) (Q. S. Ali Imran: 14).

Dengan dalil Allah tersebut serta kesadaran bahwa manusia mempunyai

fitrah sedemikian rupa, maka manusia beriman hendaknya lebih berhati-hati dalam mengatur waktu serta menempatkan segala sesuatu sesuai posisinya.

2. Bait ke-2:

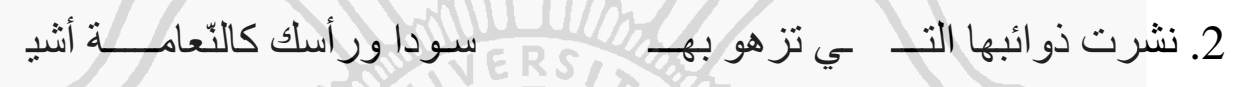

ـ نشرت ذو ائبها التي تز هو بهـا سـودا (جدائلها السود التى تتخايل بها) ور أسلك كالنّعاه

$$
\text { (شجرة التى ثمر ها وز هر ها أبيض) أثنيب (أي غز اه الثيب فبدا أبيض كر أس النعامة). }
$$

- Jalinan rambut hitamnya bercahaya (jalinan rambut hitam yang kau khayalkan) terurai sedangkan kepalamu telah beruban seperti na'amah (pohon yang bunga dan buahnya berwarna putih).

Bait kedua menggambarkan putri Si Kamu adalah perempuan yang menarik. Rambut hitamnya seakan bersinar. Ini dapat diartikan sebagai lambang kecantikan. Pantaslah jika Si Kamu sangat mencintai putrinya.

Pada bait kedua ini Si Aku menggambarkan rambut putri Si Kamu yang hitam menarik dengan rambut Si Kamu yang memutih. Dengan perbandingan tersebut, Si Aku berharap agar Si Kamu menyadari bahwa ia sudah tua, sudah waktunya untuk berhenti mencintai kehidupan dan keindahan dunia dengan berlebihan, termasuk anak. Pada dasarnya harta benda dan anak-anak adalah perhiasan dunia yang digunakan oleh Tuhan untuk menguji hamba-Nya dalam mengukur ketakwaan. Apakah dengan dikaruniai anak atau harta yang melimpah seseorang akan melupakan Tuhan ataukah malah menambah kedekatannya kepada 
Tuhan, serta lebih banyak bersyukur. Allah telah menggambarkan proses yang dialami manusia dalam firman-Nya.

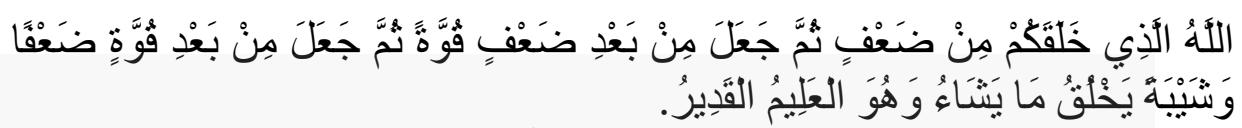

Allah, Dialah yang menciptakan kamu dari keadaan lemah, kemudian Dia menjadikan (kamu) sesudah keadaan lemah itu menjadi kuat, kemudian Dia menjadikan (kamu) sesudah kuat itu lemah (kembali) dan beruban. Dia menciptakan apa yang dikehendaki-Nya dan Dialah Yang Maha Mengetahui lagi Maha Kuasa (Q. S. Ar-Rum:54).

3. Bait ke-3:

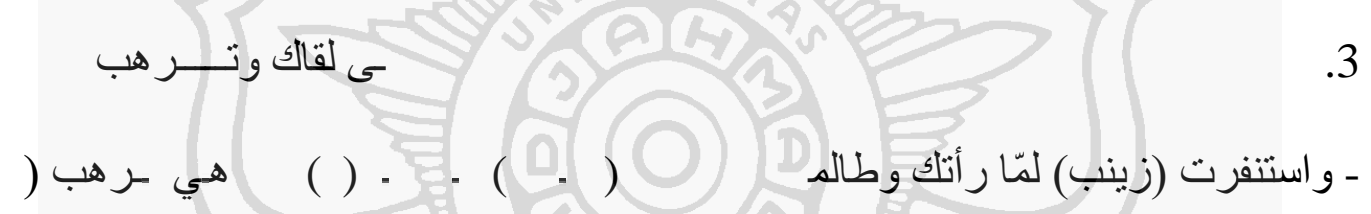

- Zainab lari tatkala melihatmu dan selalu merindukan untuk bertemu denganmu juga takut (untuk berpisah).

Bait ketiga menjelaskan tentang sifat Zainab yang seperti anak-anak kecil lainnya. Pada bait tersebut digambarkan bahwa Zainab sering menghindari Si Kamu, meskipun dalam hatinya ia selalu merindukannya dan takut untuk berpisah. Hal ini wajar terjadi jika anak dan orang tua jarang bertemu. Kemungkinan pada masa itu Si Kamu (Imam Ali) yang terkenal sebagai penakluk dan penegak hukum yang termasyhur tidak memiliki banyak waktu untuk mengurus keluarga saja. Masa waktunya banyak tersita untuk mengurusi rakyat dan memerangi musuh-musuhnya. Di sisi lain Imam Ali tidak ingin terikat dengan anak terlalu jauh hingga melupakan Tuhan karena Allah telah menyinggung hal itu dalam firman-Nya: 


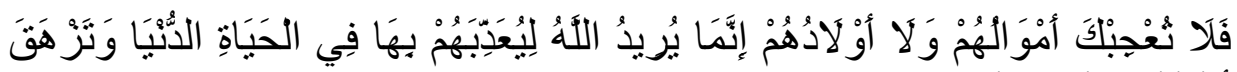

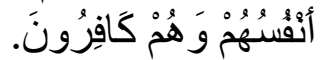

Maka janganlah harta benda dan anak-anak mereka menarik hatimu. Sesungguhnya Allah menghendaki dengan (memberi) harta benda dan anak-anak itu untuk menyiksa mereka dalam kehidupan di dunia dan kelak akan melayang nyawa mereka, sedang mereka dalam keadaan kafir (Q. S. At-Taubah: 35).

Melalui bait serta ayat ini manusia seharusnya sadar bahwa posisi anak, harta benda, dan apa yang ada di dunia ini bukanlah segalanya, melainkan cobaan bagi manusia sehingga tidak layak untuk terlalu dicintai.

4. Bait ke-4:

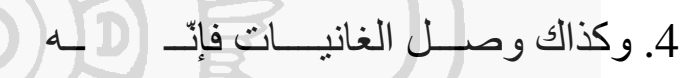

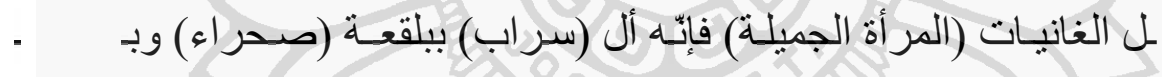

- Begitu juga kehadiran wanita cantik, hal itu merupakan fatamorgana di lembah gersang (padang pasir) juga kilat pada awan yang tak menyebabkan hujan turun.

Bait keempat menyatakan bahwa Si Aku berpandangan bahwasanya anak itu hampir sama dengan wanita cantik. Semua itu hanyalah hiasan dunia semata yang merupakan ujian dari Tuhan untuk umat-Nya. Apakah manusia akan terperosok oleh tipuan semu itu lantas melupakan Tuhan ataukah tetap pada keimanannya. Si Aku menggambarkan hal itu bagaikan fatamorgana di padang gersang atau kilat yang tidak menyebabkan hujan turun.

Allah menggambarkan tipuan fatamorgana dalam firman-Nya tatkala mensifati orang-orang kafir.

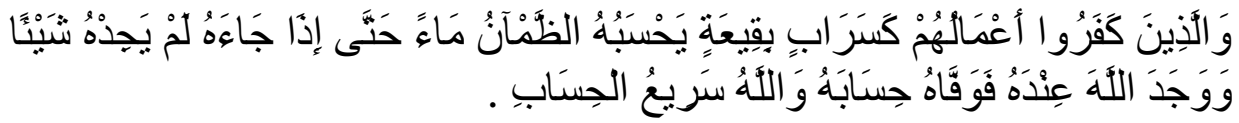


Dan orang-orang yang kafir amal-amal mereka adalah laksana fatamorgana di tanah yang datar, yang disangka air oleh orang-orang yang dahaga, tetapi bila didatanginya air itu dia tidak mendapatinya sesuatu apapun. Dan didapatinya (ketetapan) Allah di sisinya, lalu Allah memberikan kepadanya perhitungan amal-amal dengan cukup dan Allah adalah sangat cepat perhitungan-Nya (Q. S. An-Nur: 39).

Berdasar bait dan ayat tersebut, maka sebagai makhluk berakal seharusnyalah manusia berusaha mencari jalan yang benar agar tidak tertipu dengan tipuan dunia.

5. Bait ke-5;

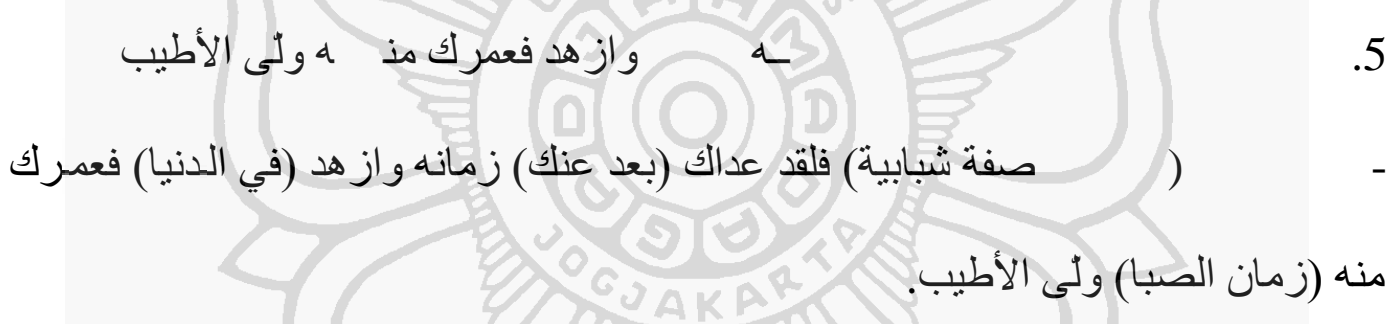

- Maka tinggalkan sifat kanak-kanak (masa muda, sifat orang muda) karena masanya telah menjauhimu, Zuhudlah (kedunianan) setelah umur mudamu kau lalui dengan keindahan.

Bait kelima, Si Aku mengajak Si Kamu untuk memulai meninggalkan masa muda. Masa muda dapat diartikan masa yang penuh keindahan dan kesenangan. Adalah wajar jika para pemuda suka bersenang-senang dan kurang memperhatikan kehidupan akhirat.

Si Aku mengajak Si Kamu untuk memulai berpikir atau mementingkan kehidupan akhirat kelak dengan mencari bekal sebanyak-banyaknya. Si Aku menyadarkan Si Kamu bahwa umurnya sudah tidak tepat untuk bergaya hidup seperti orang muda. Banyak ayat Al-Qur'an yang mengajak dan memperingatkan 
manusia agar berzuhd dan tidak terlalu mementingkan dunia, diantaranya ayat berikut.

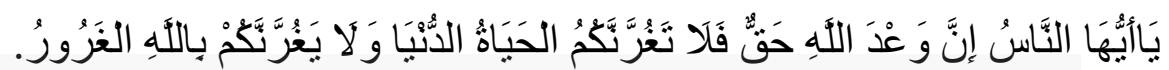

Hai manusia, sesungguhnya janji Allah adalah benar, maka sekali-kali janganlah kehidupan dunia memperdayakan kamu dan sekali-kali janganlah setan yang pandai menipu, memperdayakan kamu tentang Allah (Q. S. Fatir: 5).

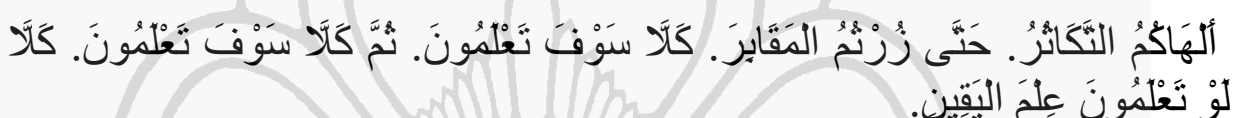

Bermegah-megahan telah melalaikan kamu, sampai kamu masuk ke dalam kubur. Janganlah begitu, kelak kamu akan mengetahui (akibat perbuatanmu itu), dan janganlah begitu, kelak kamu akan mengetahui. Janganlah begitu, jika kamu mengetahui dengan pengetahuan yang yakin (Q. S. At-Takasur:1-5).

6. Bait ke-6:

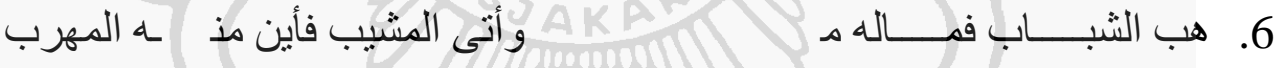

$$
\begin{aligned}
& \text { ـ ذهب الثبـاب فمـاله من عودة وأتى المشيب فأين منـه المهرب. }
\end{aligned}
$$

- Masa muda telah pergi dan tak akan kembali, sedang masa tua datang dan akan lari ke mana untuk menjauhinya.

Bait keenam, Si Aku menegaskan bait sebelumnya bahwasanya masa muda telah dilewati dan tak akan kembali karena waktu tak bisa dihentikan dan terus berjalan, sedangkan masa tua tak dapat ditolak.

Allah telah bersumpah dalam surat Al-'Asr bahwasanya manusia dalam keadaan rugi kecuali orang yang beramal saleh. Oleh karena itu, Si Aku mengajak agar Si Kamu lebih mementingkan kehidupan akhirat.

7. Bait ke-7:

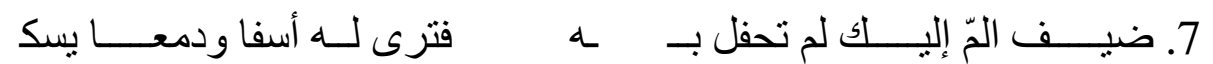




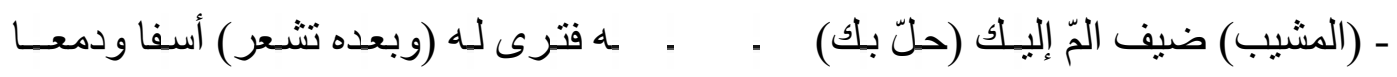

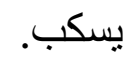

- Tamu (uban) datang kepadamu, sedang kamu tidak mengindahkannya, maka kamu akan melihatnya (setelah merasakan kehadirannya) dalam keadaan menyesal dan bercucuran air mata.

Bait ketujuh masih berkaitan dengan bait sebelumnya, bahwasanya jika Si Kamu tidak mengindahkan tanda yang diberikan Tuhan, maka ia akan menyesal. Orang yang berakal sehat pasti akan menyadari bahwa uban diciptakan Tuhan untuk memberi isyarat bahwa manusia tersebut sudah semakin mendekati ajal, maka sepantasnya manusia lebih bersiap diri untuk menghadap Tuhan dengan memperbanyak amal saleh. Sehingga manusia yang tidak bersiap-siap akan termasuk orang yang rugi di akhirat.

Pada zaman sekarang kebanyakan orang mengingkari tanda yang diberikan Tuhan tersebut. Manusia ingin selalu kelihatan muda. Manusia mengingkari rambut yang sudah memutih dengan mengecatnya menjadi hitam. Manusia sibuk merias diri dengan bermacam-macam perawatan tubuh untuk menutupi penuaan, padahal maut tak bisa diundur waktunya. Allah SWT telah berfirman.

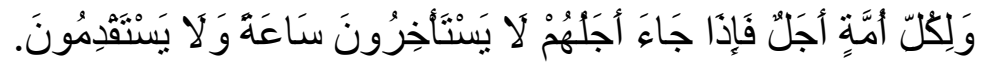
Tiap-tiap umat mempunyai batas waktu; maka apabila telah datang waktunya mereka tidak dapat mengundurkannya barang sesaatpun dan tidak dapat (pula) memajukannya (Q. S. Al-A'raf:34).

8. Bait ke-8:

الك و ابكهـــا با مذنب 


$$
\text { - دع عنك ما قد فات في زمن الصبا واذكر ذنوبـلك و ابكها يا مذنب. }
$$

- Tinggalkan apa yang telah lewat saat masa mudamu. Ingatlah dosa-dosamu, Hai orang yang berdosa.

Bait kedelapan menegaskan tiga bait sebelumnya bahwa Si Aku mengajak Si Kamu untuk melupakan kesenangan hidup di masa muda, dan mengajak Si Kamu mengingat dosa-dosa dengan harapan dapat lebih mendekatkan diri pada Tuhan. Berkaitan dengan dosa, Allah berfirman.

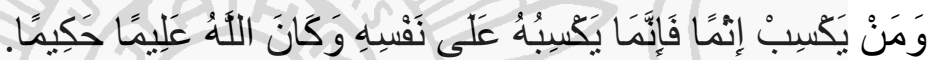

Barangsiapa yang mengerjakan dosa, maka sesungguhnya ia mengerjakannya untuk (kemudharatan) dirinya sendiri. Dan Allah Maha Mengetahui lagi Maha Bijaksana (Q. S. An-Nisa:111).

Sudah jelas bahwasanya umur manusia semakin berkurang dan dosanya bertambah banyak, sedangkan Allah mengetahui segala perbuatan manusia, bahkan niat yang ada dalam hati. Oleh karena itu manusia beriman seharusnya selalu berusaha memperbaiki diri, bertobat selama masih hidup di dunia.

9. Bait ke-9 dan 10:
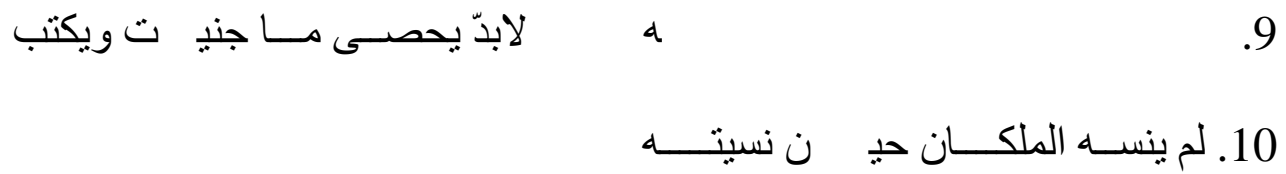

- و اخش(عليك أن تخاف) مناقثة الحسـاب (في أخرتك) فإنّه لابدّ يحصسى مـا جنيت ويكتب.

$$
\text { لم ينســه الملكان حين نسيتهـه بـل أثتبتـاه (دوّناه) و أنت لاه (غافل) تلعب }
$$

- Takutlah (kau harus takut) akan ujian hari perhitungan amal ( kelak di akhirat).

Karena apa yang kamu perbuat akan dihitung dan di catat. 
- Dua malaikat tak akan melupakan amal/ dosamu ketika kamu melupakannya, bahkan menetapkannya (membukukannya) sedang kamu lupa (orang yang lupa) dan bermain-main.

Bait kesembilan dan kesepuluh menegaskan bahwasanya setelah Si Aku menyarankan untuk meninggalkan masa muda, ia kemudian mengingatkan $\mathrm{Si}$ Kamu agar memperhatikan dan mempersiapkan diri guna menghadapi ujian pertanggungjawaban amal kelak di hari perhitungan amal di akhirat, saat manusia tidak bisa mengingkari dosa-dosa yang telah diperbuatnya karena semuanya tercatat oleh malaikat. Mengenai perhitungan amal Allah telah menyinggung dalam firman-Nya.

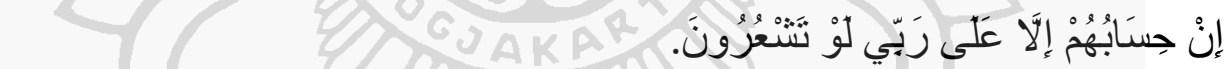
Perhitungan (amal perbuatan) mereka tidak lain hanyalah kepada Tuhanku, kalau kamu menyadari (Q. S. Asy-Syuara:113).

Dengan melihat bait di atas manusia selayaknya berhati-hati dalam berbuat, tidak meremehkan perbuatan dosa serta mencari bekal di dunia untuk kepentingan akhirat.

10. Bait ke-11:

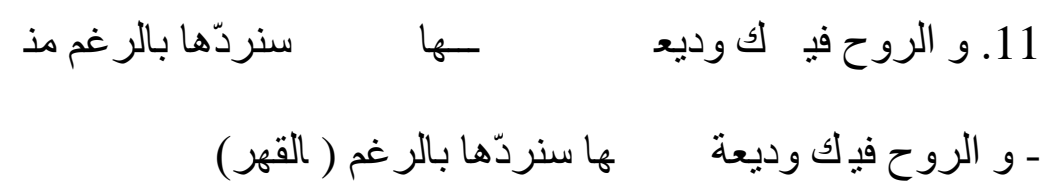

- Adapun roh pada dirimu adalah titipan yang dititipkan, akan dikembalikan/ ditarik dengan paksa dan dirampas darimu.

Bait kesebelas Si Aku mengingatkan bahwasanya roh sebagai inti kehidupan merupakan titipan Allah semata. Sebagaimana barang titipan, roh menjadi beban amanat bagi orang yang dititipi. Dia harus ikhlas dan rela 
manakala barang titipan tersebut diminta kembali oleh pemiliknya. Orang yang dititipi tidak mempunyai hak memiliki meskipun titipan itu dekat denganya dan ia mencintainya. Begitu halnya dengan roh yang sewaktu-waktu akan ditarik kembali dari jasad manusia dengan paksa. Manusia tidak dapat menahan kepergian roh saat diambil kelak.

Tidak ada seorangpun yang benar-benar memahami roh. Roh tidak dapat digambarkan dengan apapun juga, roh merupakan hal gaib yang tidak ditemukan padanannya di alam dunia. Rasulullah pernah dimintai keterangan mengenai roh, dan Allah dalam firman-Nya menjawab.

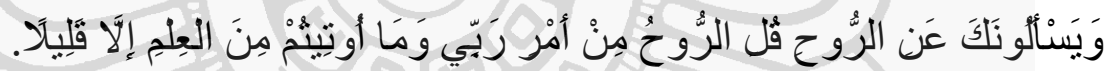
Dan mereka bertanya kepadamu tentang roh. Katakanlah: "Roh itu termasuk urusan Tuhan-ku, dan tidaklah kamu diberi pengetahuan melainkan sedikit" (Q. S. Al-Isra: 85).

Jadi Rasulpun hanya sedikit tahu perihal roh. Roh merupakan hal gaib yang harus diimani. Roh bisa dirasakan, tetapi tidak nampak. Kaitannya dengan kematian, bahwasanya jika roh telah ditarik dari jasad, maka seseorang akan mati. Penarikan roh itu merupakan hak Allah yang tidak dapat diganggu siapapun. Firman Allah menegaskan sebagai berikut.

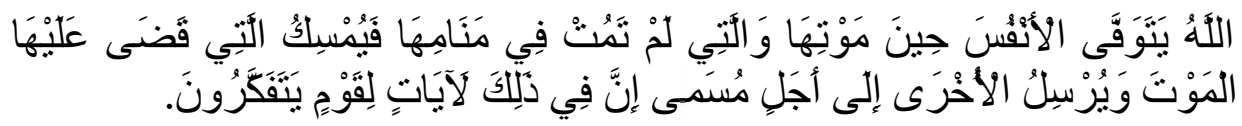

Allah memegang jiwa (orang) ketika matinya dan (memegang) jiwa (orang) yang belum mati di waktu tidurnya; maka Dia tahanlah jiwa (orang) yang telah Dia tetapkan kematiannya dan Dia melepaskan jiwa yang lain sampai waktu yang ditentukan. Sesungguhnya pada yang demikian itu terdapat tanda-tanda kekuasaan Allah bagi kaum yang berfikir (Q. S. Az-Zumar: 42). 
Oleh karena itu, Si Aku menyadarkan Si Kamu untuk tidak mensiasiakan umur yang diberikan oleh Allah. Selayaknya ia selalu mempersiapkan bekal untuk menghadapi maut yang tidak diketahui waktu kedatangannya. Nabi mengajarkan untuk membaca doa saat menjelang tidur, dengan harapan seseorang dapat selamat dari godaan setan. Selain itu sebagai persiapan jikalau Allah mencabut nyawa orang tersebut ia dapat tergolong mati husnul hatimah.

11. Bait ke-12:

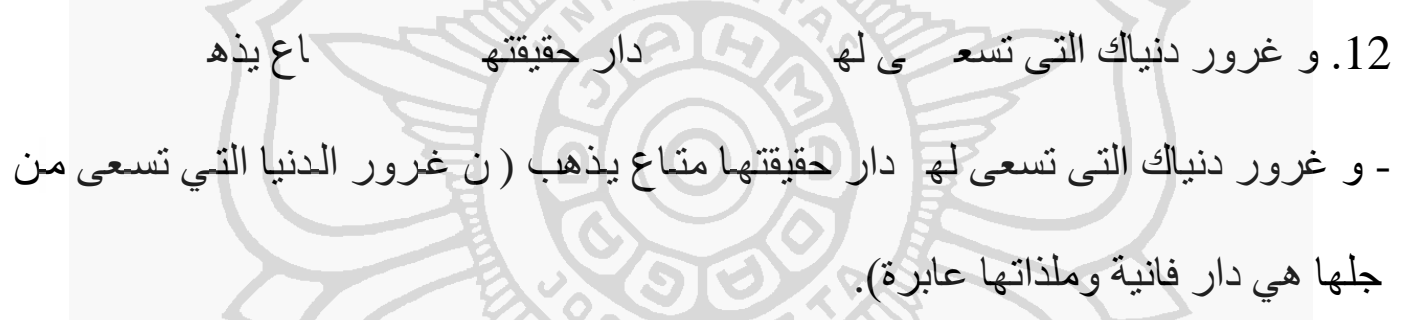

- Tipu daya dunia yang kamu usahakan adalah rumah, hakikatnya adalah perhiasan yang akan pergi (bahwasanya tipuan dunia yang kamu cari merupakan tempat yang fana serta keenakannya akan hilang).

Dunia beserta isinya merupakan perhiasan yang diperuntukkan bagi manusia selaku khalifah Allah di muka bumi. Seindah apapun barang dunia yang diperoleh tentu pada suatu masa akan habis dan hilang. Sebanyak apapun barang dunia, ia tidak akan kekal. Banyak sekali manusia yang tertipu dengan kesenangan dunia semata. Mereka tidak menyadari bahwa perbuatan mereka akan mencelakakan diri mereka sendiri kelak di akhirat. Dalam surat Luqman Allah memperingatkan.

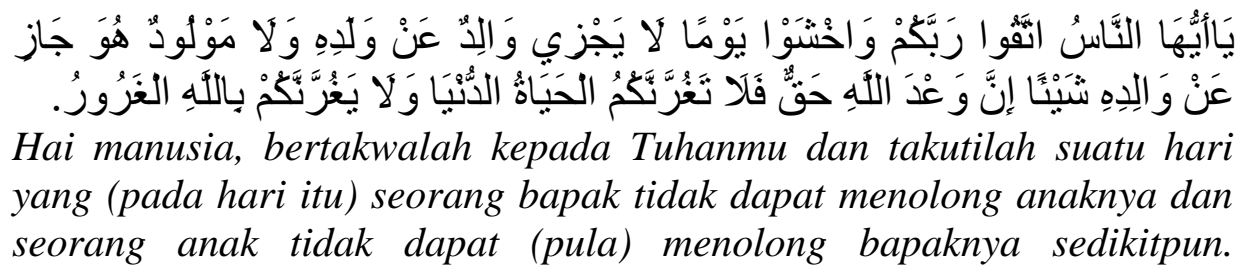


Sesungguhnya janji Allah adalah benar, maka janganlah sekali-kali kehidupan dunia memperdayakan kamu, dan jangan (pula) penipu (setan) memperdayakan kamu dalam (mentaati) Allah. (Q S. Luqman: 33.)

Oleh sebab itu, tidak layak jika manusia hanya sibuk mengurus hal-hal dunia semasa hidupnya. Manusia harus memikirkan pula kehidupan yang digunakan sebagai bekal kelak hidup di akhirat yang kekal.

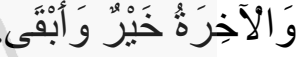

Sedang kehidupan akhirat adalah lebih baik dan lebih kekal. (Q. S. AlA'la:17).

Allah telah menegaskan bahwa kehidupan akhirat jauh lebih baik dari kehidupan dunia. Oleh karena itu, seharusnya manusia lebih mengedepankan kehidupan akhirat. Meskipun kehidupan akhirat merupakan hal gaib, tetapi sebagai orang yang beriman tentunya berusaha untuk mengimani dan membenarkan akan datangnya kehidupan akhirat kelak.

12. Bait ke-13:

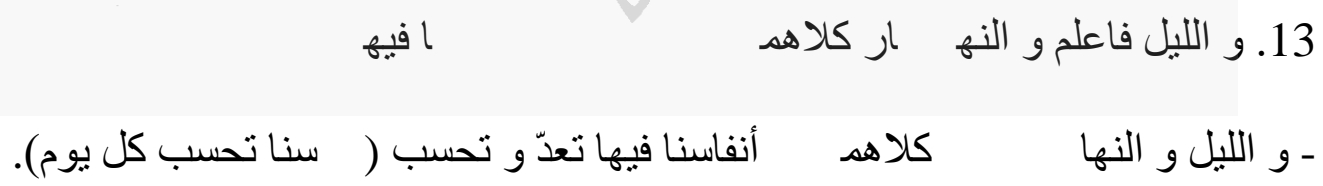

- Adapun malam dan siang, ketahuilah bahwa napas kita pada keduanya dipilahpilah dan dihitung (napas kita dihitung setiap hari).

Si Aku menegaskan bahwasanya napas manusia setiap hari, pagi, siang, sore, dan malam senantiasa dihitung dan dipilah-pilah. Manakah di antaranya yang diiringi dzikir dan ibadah kepada Allah. Setiap napas diikuti pertanggungjawaban kelak di akhirat. 
Si Aku ingin mempertegas dengan keterangan ini bahwasanya jika napas yang kadangkala tidak disadari oleh manusia dihitung dan dipilah antara yang diringi dzikir ataupun maksiat, tentu saja amal yang lebih jelas dan disadari manusia selalu ada pertanggunganjawabannya kelak. Hal ini menyatakan juga bahwa $\mathrm{Si} \mathrm{Aku}$ termasuk orang yang sangat berhati-hati. Ia mengajak memperhatikan hal-hal ibadah yang berawal dari hal yang mungkin dianggap remeh oleh orang pada umumnya. Allah telah memberikan perumpamaan ketelitian perhitungan-Nya terhadap amal manusia dalam ayat berikut.

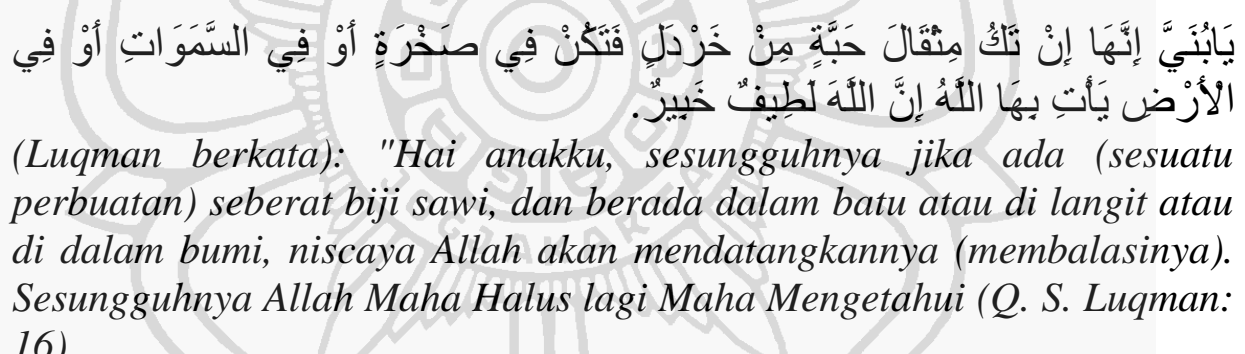
16).

Sikap yang seharusnya dimiliki oleh orang beriman, berdasar bait di atas adalah tidak meremehkan hal-hal yang kecil, melainkan memperhatikannya dan berusaha melaksanakannya dengan penuh tanggung jawab.

13. Bait ke-14:

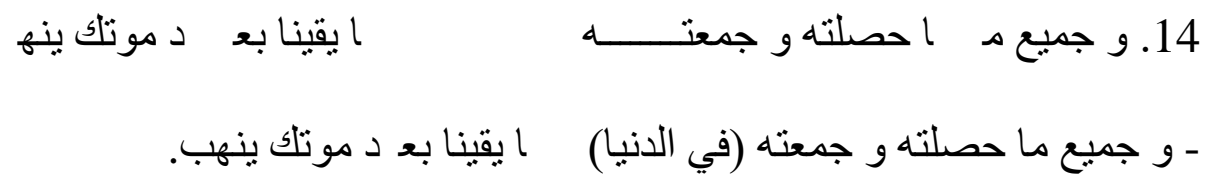

- Segala sesuatau yang kamu hasilkan dan kumpulkan (di dunia ini) benar-benar akan dirampas setelah kamu mati.

Pada bait ini Si Aku ingin menegaskan bahwa segala harta yang dikumpulkan manusia selama hidupnya tidak akan berarti apa-apa. Semua akan ditinggalkan dan bukan lagi menjadi miliknya. Oleh karena itu, tidak selayaknya 
manusia hanya sibuk mengumpulkan harta, melainkan ia juga harus memperhatikan hak-hak fakir miskin melalui zakat dan sadaqah.

14. Bait ke-15:

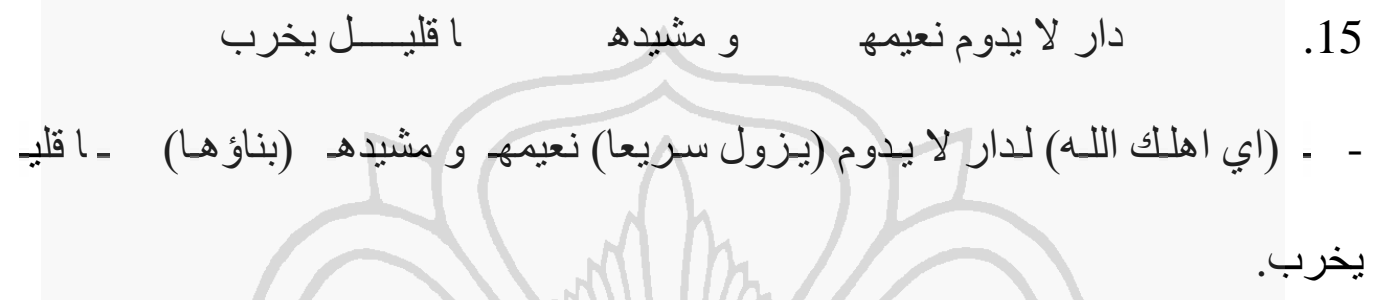

- Kecelakaan (Allah akan merusak) bagi negeri yang nikmat-nikmatnya dan bangunan-bangunannya tidak kekal (akan menghilang secepatnya), dan sedikit demi sedikit akan ditenggelamkan.

Si Aku mempertegas dengan mengutuk kehidupan duniawi. Si Aku ingin meyakinkan Si Kamu untuk/lebih mementingkan kehidupan akhirat. Ia menyatakan bahwa sekokoh apapun bangunan di dunia tetap saja suatu saat akan hancur dan tidak ada kehidupan dunia yang kekal. Rasulullah pernah menyatakan dalam hadisnya sebagai berikut.

ألا إنّ الدنيا ملعون ما فيها إلا ذكر الله و ماو الاه و عالم أو متعلم (رواه الترمذي) Ingatlah, sesungguhnya dunia itu terkutuk, terkutuk pula semua yang ada padanya kecuali zikrullah dan hal-hal yang menunjangnya serta orang yang alim atau yang belajar ilmu (Riwayat At-Turmudzi)

Menurut hadis ini dunia dan semua yang ada di dalamnya terkutuk dan dijauhi oleh Allah dan hamba-Nya kecuali zikrullah, yaitu beribadah kepada Allah, dan hal-hal yang menunjang untuk beribadah. Tidak terkutuk pula ahli ilmu syariat yang mengamalkannya dengan ikhlas, semua itu disukai Allah (Nasif, 2003:489). 
15. Bait ke-16:

$$
\text { 16. فاسمع هديت نصائد ا أولا كهة }
$$

- Dengarlah, Kamu telah diberi petunjuk (oleh Allah) dengan nasihat yang disampaikan oleh orang yang baik, cerdas, berakal dan berpendidikan.

Setelah mengawali pembicaraan mengenai betapa fana kehidupan dunia, dan betapa akhirat lebih patut untuk diutamakan, Si Aku kemudian beranjak untuk memberikan nasihat-nasihatnya kepada $\mathrm{Si}$ Kamu. Di sini, Si Aku menegaskan bahwa Si Kamu tahu persis siapa Si Aku yang tak lain dirinya sendiri merupakan orang yang berpengetahuan luas dalam berbagai bidang ilmu, terlebih ilmu agama. Oleh karena alasan itulah, sudah sepantasnya Si Kamu mau mendengar nasihat hatinya yang diucapkan melalui Si Aku tersebut.

16. Bait ke-17:

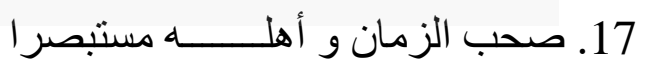

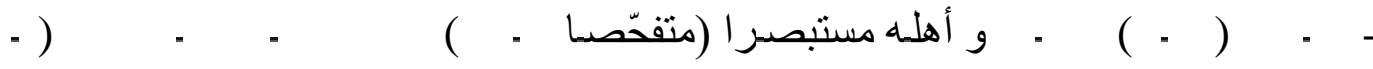

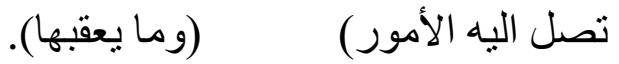

- Pergaulilah zaman dan penghuninya dengan membuka mata (dengan teliti, cermat), dan lihatlah semua yang kau capai serta akibatnya kepadamu.

Kata - (sahiba) 'dia telah menemani', di sini adalah kata kerja dengan bentuk fi'l madi yang beriringan dengan waktu lampau, sedangkan yang dimaksud adalah kata صـب (ishab) 'temanilah', yaitu fi'l amrnya yang 
menunjukkan arti perintah. Namun, fi'l amr menunjukkan waktu yang akan datang, padahal Si Aku ingin menunjukkan makna 'terus menerus'. Makna ini dapat diungkapkan dengan memakai kata kerja berwaktu lampau, fi'l madi. Sehingga makna yang ditafsirkan adalah ajakan agar $\mathrm{Si}$ Kamu selalu memperhatikan waktu.

Si Aku menghimbau Si Kamu bagaimana menyikapi kehidupan dunia, bagaimana menyikapi waktu. Bahwasanya manusia harus belajar dari waktu. Manusia haruslah membuka mata, maksudnya tidak melewatkan waktu yang berlalu dengan sia-sia. Manusia harus mempunyai waktu untuk bertafakkur, memikirkan apa yang telah diperoleh selama waktu yang telah dilalui. Apakah manfaat dari apa yang telah dicapai lebih banyak daripada mafsadahnya (kerusakan, kesia-siaan).

17. Bait ke-18:

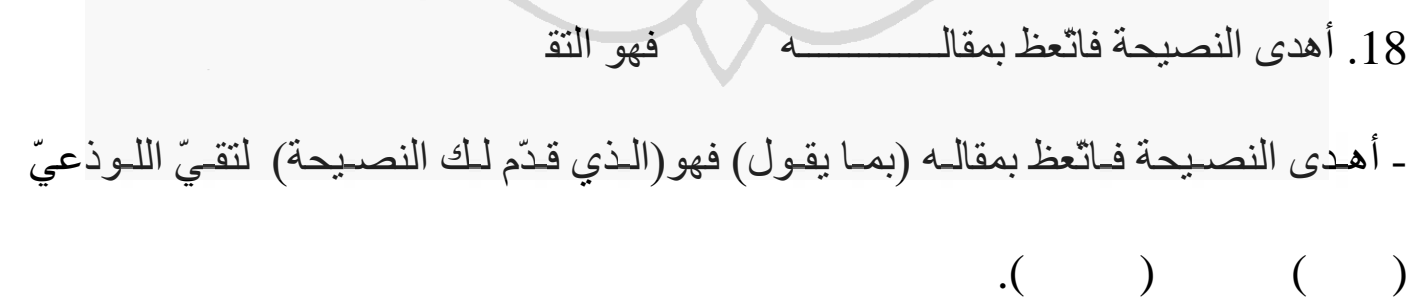

- Dia memberikan nasihat, maka perhatikanlah ucapannya. Dia (orang yang menasihatimu) adalah orang bertaqwa, cerdas dan terampil/ terlatih.

Si Aku meminta Si Kamu memperhatikan nasihatnya dengan sungguhsungguh. Pada bait ini terdapat dua kata yang artinya hampir mirip, tetapi berbeda maknanya, yaitu kata nasihah dan mauizah.

Dalam kamus lisan al Arab disebutkan bahwasanya nasihat dapat diartikan sebagai kalimat atau kata-kata yang disampaikan seseorang kepada 
orang lain dengan tujuan agar orang yang diberi tahu menjadi lebih baik. Sedangkan mauizah lebih mendekati pada arti pelajaran, dengannya diharapkan agar pendengar dapat mengambil pelajaran dari apa yang telah disampaikan orang yang berbicara (Ibnu Manzur Jilid ta, sa, jim, ha, tt:615).

Dalam bait ini Si Aku memakai kedua kata itu untuk memperkuat ucapannya. Diharapkan Si Kamu memperhatikan nasihatnya yang berupa bait-bait puisi ini untuk dapat diambil pelajaran, kemudian dipakai dalam kehidupan sehari-hari.

18. Bait ke-19:

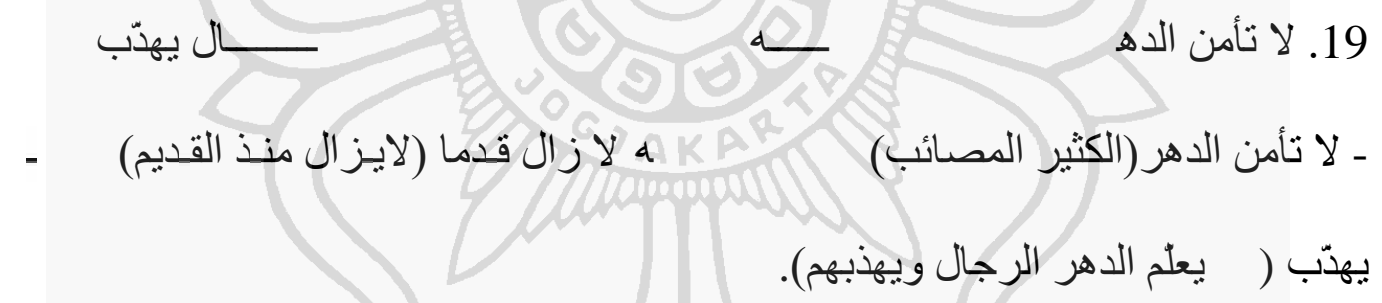

- Jangan diamkan masa (yang penuh cobaan) yang telah berlalu. Sesungguhnya dari dulu waktu selalu mendidik orang-orang yang terpelajar.

Tidak seharusnya manusia melewatkan masa yang telah berlalu tanpa memetik pelajaran dan hikmah yang terkandung di dalamnya. Sejarah merupakan guru terbaik. Dari pengalaman orang dapat menentukan sikap sehingga tidak terjerumus dalam kesalahan yang sama. Si Aku ingin menyatakan dalam bait ini bahwa hanya orang bodoh yang tidak belajar dari waktu.

Allah seringkali mengakhiri ayat dengan keterangan bahwa ayat tersebut sebagai pelajaran bagi orang orang yang berfikir. Allah juga menegaskan bahwa Dia mengangkat derajat orang yang berilmu dan orang-orang yang bertaqwa.

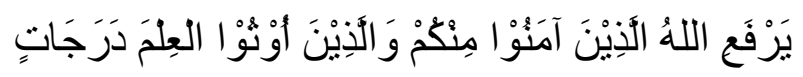


Allah meninggikan orang-orang yang bertakwa di antara kamu dan orang-orang yang mempunyai ilmu beberapa derajat $(Q . \quad S$. alMujadalah:11).

Allah juga menegaskan bahwasanya orang berilmu tidak sama dengan orang yang tidak berilmu, tidak sama dalam perbuatan, pola pikir, ucapan dan lain sebagainya.

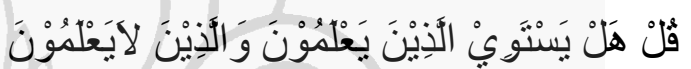

Katakanlah (Muhammad) apakah sama antara orang yang mengetahui dengan orang yang tidak mengetahui (Q. S. az-Zumar:9).

Allah menganjurkan agar manusia selalu berpikir. Oleh karena itu, orang beriman haruslah selalu mensyukuri nikmat yang diberi Allah berupa akal untuk selalu berpikir.

19. Bait ke-20:

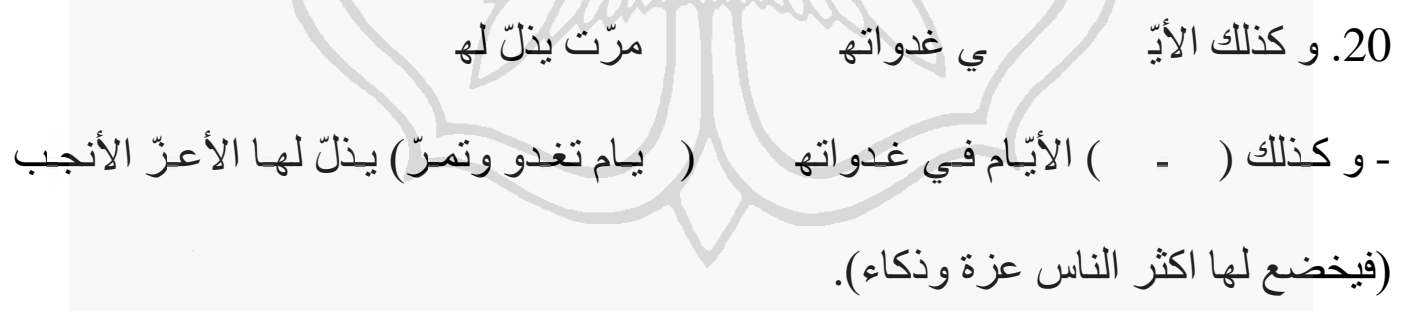

- Begitu juga (jangan diamkan) hari-hari, paginya berlalu. Orang yang mulia dan berkedudukan tinggi akan direndahkan karenanya.

Manusia harus benar-benar memperhatikan waktu. Jangan sampai tidak dapat menyikapi waktu dengan benar. Waktu ibarat pedang yang akan memotong orang yang memegangnya, jika tidak dapat mempergunakannya dengan benar. Kelak di akhirat akan terlihat bahwa kebanyakan orang merugi karena tidak dapat mempergunakan waktu. Allah telah bersumpah bahwa kebanyakan manusia tidak dapat menyikapi waktu dengan baik sehingga mereka dalam kerugian. 


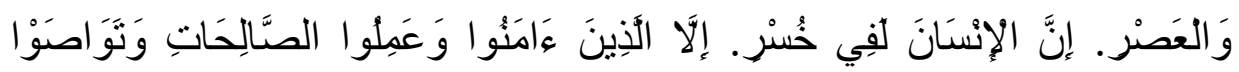

Demi masa. Sesungguhnya manusia itu benar-benar berada dalam kerugian, kecuali orang-orang yang beriman dan mengerjakan amal saleh dan nasihat menasihati supaya mentaati kebenaran dan nasihat menasihati supaya menetapi kesabaran (Q. S. Al-Ashr: 1-3).

Kata الأيّ dimaksudkan bukan dengan hari secara harfiah, tetapi untuk dipahami lebih dalam, yaitu hari yang di dalamnya terdapat rutinitas kegiatan. Dalam bait ini Si Aku ingin menyatakan bahwa orang yang berpangkat dan berkedudukan tinggi sekalipun akan mengalami kerugian jika tidak mengisi hari-harinya dengan kegiatan yang berguna. Kedudukan, pangkat dan kekayaan mempunyai batas waktu. Setelah lewat beberapa hari, tahun atau abad tentu akan hilang dan habis, tidak berarti lagi. Oleh karena itu, seseorang harus menggunakan apa yang dimilikinya sebaik mungkin, menyisihkan untuk bekal di akhirat agar kelak tidak menjadi orang yang rugi, sebelum barang-barang dunia yang ada di sisinya hilang atau tak berarti lagi apabila telah mati.

20. Bait ke 21:
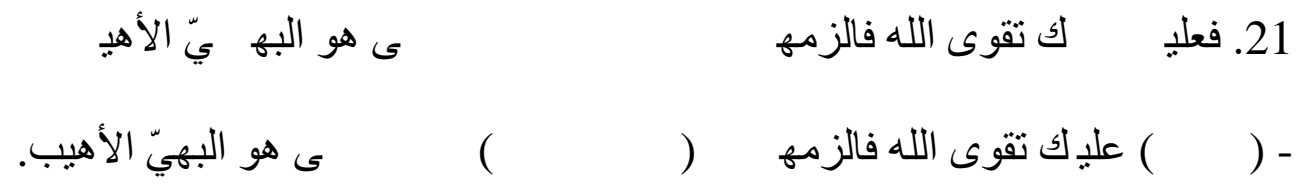

- Kamu harus takut kepada Allah, dan berpegang teguhlah niscaya kamu akan beruntung. Sungguh, takwa itu rasa takut yang terbaik.

Bait ini merupakan himbauan Si Aku agar Si Kamu senantiasa takut kepada Allah. Takut di sini dapat pula diartikan takwa kepada Allah. Menurutnya sebaik-baik rasa takut adalah takwa kepada Allah. Allah menyatakan dalam firman-Nya bahwa sebaik-baik bekal adalah takwa. 


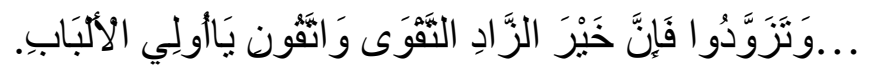

...berbekallah, dan sesungguhnya sebaik-baik bekal adalah takwa dan bertakwalah kepada-Ku hai orang-orang yang berakal (Q. S. AlBaqarah: 197).

Rasa takut merupakan salah satu bukti orang beriman. Sesuai dengan firman Allah.

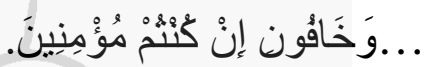

...takutlah kepadaKu, jika kamu benar-benar orang yang beriman (Q.S. Ali Imran: 175).

Takut kepada Allah memastikan kesempurnaan iman, karena hal itu timbul dari rasa selalu berada di bawah pengawasan Allah Swt dan merasakan keagungan serta kebesaran-Nya (Nasif, 2003:606).

Abu Hurairah R.a. menceritakan bahwa Raulullah Saw pernah bersabda tentang kengerian-kengerian kematian dan alam kubur serta kejadian-kejadian setelahnya yang diketahui oleh Nabi dalam hadis berikut (Nasif, 2003:606).

$$
\text { لو تعلمون ما أعلم لضحكتم قليلا و لبكيتم كثير ا (رو اه البخار و الترّذي) }
$$

Seandainya kalian mengetahui apa yang aku ketahui, niscaya kalian sedikit tertawa dan banyak menangis (Riwayat bukhari dan turmudzi).

21. Bait ke-22:

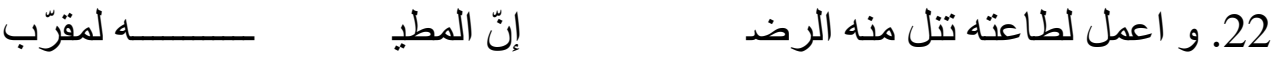

$$
\begin{aligned}
& \text { - و اعمل لطاعته تنل منه الرضد إنّ المطيع لربّه لمقرّب. }
\end{aligned}
$$

- Berbuatlah untuk mentaati-Nya, niscaya kau peroleh ridla-Nya. Sesungguhnya orang yang taat pada Tuhannya akan didekatkan.

Si Aku menghimbau agar Si Kamu taat kepada Allah. Dengan taat ridlaNya akan diperoleh selain akan lebih mendekatkan jarak dengan Tuhannya. 
Sebagai orang beriman, taat kepada Allah merupakan hal wajib, bahkan tidak hanya kepada Allah, melainkan kepada Nabi, pemerintah, orang tua, guru dan sebagainya dalam rangka mentaati perintah Allah.

Si Aku memakai kata . "berbuatlah untuk mentaati-Nya!", tidak langsung dengan kata "taatilah". Dapat dimaksudkan bahwa sebagai orang yang beriman, maka dalam melakukan sesuatu harus diniatkan semata-mata untuk berbuat taat pada Allah, melakukan hal yang sesuai dengan jalur-jalur agama Islam. Jadi ketaatan kepada Allah selalu teriring dalam setiap perbuatan orang beriman.

22. Bait ke-23:

$$
\text { و اليأس مدّا فات فهو }
$$

- Qana'ahlah, di dalam qana'ah terdapat kelapangan. Adapun mengetahui hal-hal yang sudah dilalui dan dijalani itu dituntut.

Si Aku mengatakan bahwa dengan qana'ah seseorang akan memperoleh kelapangan. Kelapangan dapat mencakup kelapangan dalam hal rizki. Hal ini berkaitan dengan prinsip barakah. Dalam kamus lisanul Arab disebutkan bahwa barakah berarti tambah atau tambahan (Ibnu Manzur Jilid qaf, kaf. tt:395). Banyak atau sedikit rizki yang diperoleh seseorang jika ia sabar dan qana'ah, maka Allah akan mencukupkan rizkinya, meskipun sedikit ia tidak merasa kekurangan.

Kelapangan juga dapat dimaksudkan dengan kelapangan hati. Orang yang qana'ah hatinya akan merasa damai, tidak mengharapkan apa yang memang 
tidak diberikan oleh Allah kepadanya. Terdapat hadis yang berkaitan dengan qana'ah, yaitu yang diriwayatkan Abi Hurairah dan Abdullah Ibn Umar sebagai berikut (Yahya,1994:118).

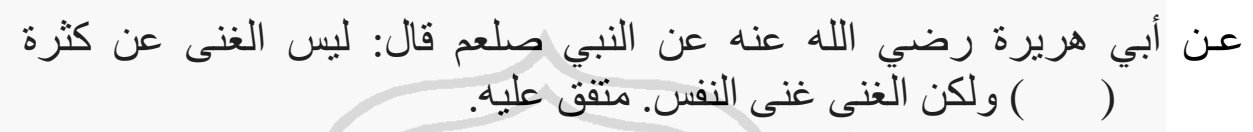

Kekayaan bukanlah dengan banyaknya harta, melainkan kaya adalah kaya hati.

و عن عبدالله بـن عمرو رضي الله عنهما أن رسول الله صلعم قال: قد أفلح من وقنّعه الله بما أتاه. رو رواه مسلم.

Benar-benar beruntung orang yang masuk Islam, diberi rizki pas-pasan, dan Allah menjadikannya orang Qana'ah atas yang diberikan-Nya.

Pada bagaian kedua bait ini Si Aku menyebut kata اليأس (al-ya`su) yang dapat diartikan dengan (al-ilmu) yang berarti tahu atau mengetahui. Jadi diharapkan seseorang mengetahui atau mencermati apa yang telah dilewati dan dilakukan pada masa yang telah dilampauinya untuk dijadikan perhatian dan pelajaran agar di hari depan tidak melakukan kesalahan dan tidak menyesal.

23. Bait ke-24:

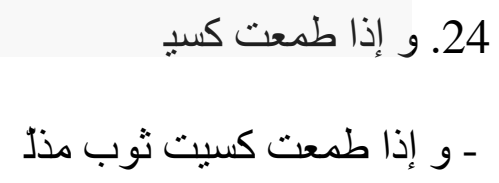

- Jika kamu tamak, kau akan diberi pakaian kehinaan. Sungguh telah diberi baju kehinaan, yaitu beruban.

Si Aku memperingatkan bahwa tamak hanya akan menyebabkan kehinaan. Selanjutnya Si Aku menyinggung Si Kamu bahwasanya Si Kamu telah beruban, tentu saja akan lebih hina jika seorang yang telah tua sepertinya masih tamak, padahal uban merupakan sebuah peringatan Allah. 
Tamak merupakan kebalikan dari sifat qana'ah. Orang tamak tidak akan pernah merasa puas dengan apa yang telah diperolehnya, bahkan selalu menginginkan segala sesuatu yang belum dipunyai untuk dimiliki. Orang tamak bahkan dapat merendahkan dirinya sendiri demi mencapai keinginannya.

24. Bait ke-25, 26, 27, dan 28:

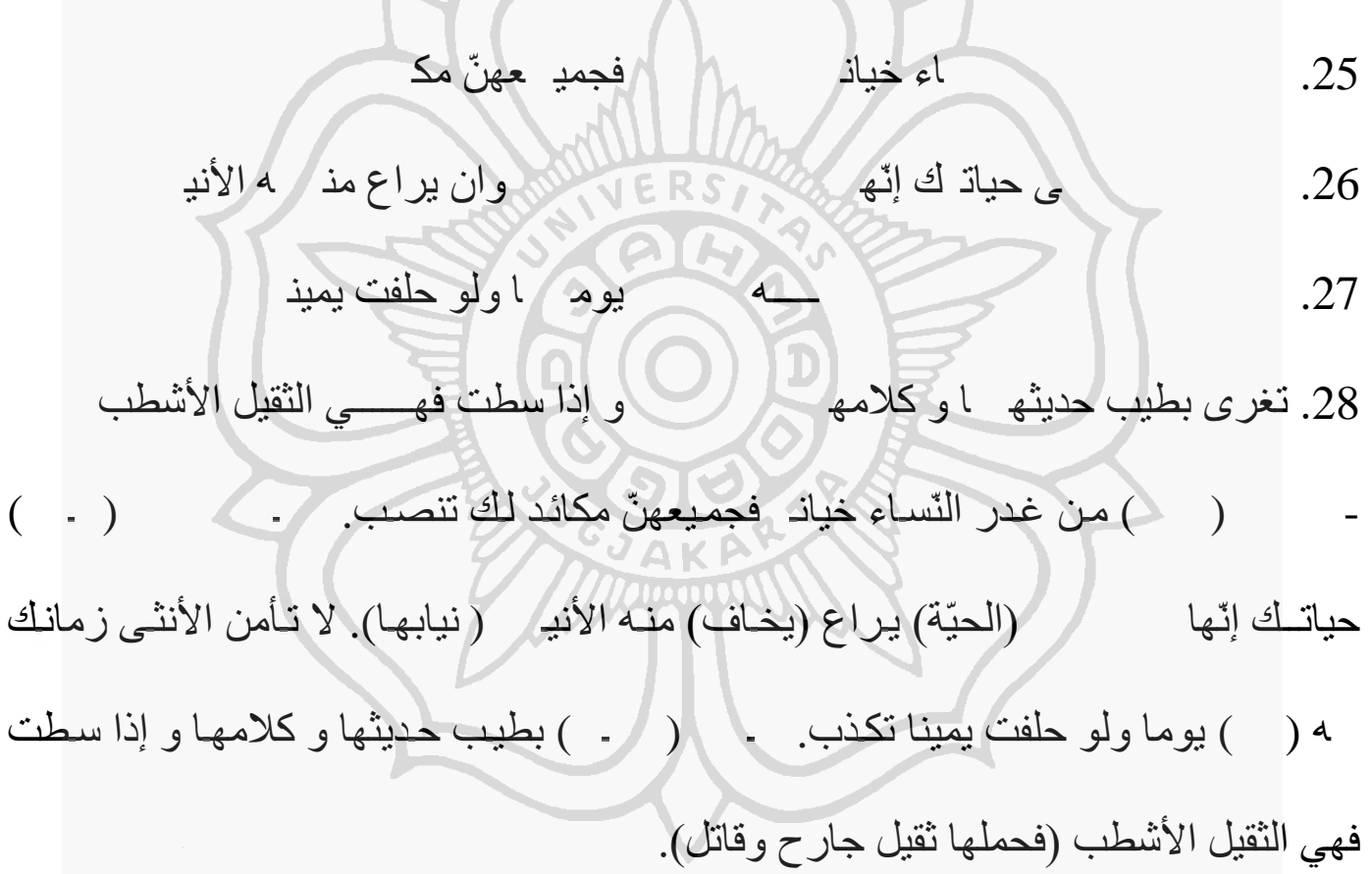

- Berhati-hatilah dari pengkhianatan wanita, mereka diadakan/ciptakan sebagai tipu daya bagimu. Jangan percayai wanita sepanjang masamu. Sesungguhnya mereka seperti ular yang ditakuti bisanya/ taringnya. Jangan percayai wanita seumur hidupmu, walaupun sehari. Mereka akan berdusta meskipun telah bersumpah. Mereka (para wanita) memikat dengan perkataan dan ucapan yang manis, kemudian tatkala menyerang mereka adalah pedang paling berat (mereka menjadi pembunuh).

Si Aku berbicara tentang wanita dari sisi dapat merubah mental. Ia memperingatkan Si Kamu agar sungguh-sungguh berhati-hati dengan wanita. 
Menurutnya, wanita diciptakan sebagai tipu daya bagi orang beriman. Sejarah telah mencatat tentang kehebatan para wanita dalam mempengaruhi kaum pria. Banyak pemerintahan runtuh akibat ulah wanita.

Dalam bait di atas Si Aku mencoba menggambarkan wanita dilihat dari sudut pandang pria. Dalam pandangan pria, wanita merupakan makhluk yang diciptakan Allah dengan segala keindahan. Setiap bagian dari tubuhnya merupakan pemikat bagi pria. Di sisi lain wanita lebih mengutamakan perasaan dari pada akal. Oleh karena itu, tidak sepantasnya jika melibatkan wanita dalam hal pemikiran karena suatu saat wanita hanya memakai perasaan dalam berpendapat, ia tidak lagi melihat kebenaran di hadapannya. Selanjutnya wanita ditakdirkan Allah untuk suka merias diri dan mempunyai keinginan lebih kuat dari lelaki untuk dapat diperhatikan oleh lawan jenisnya.

Dengan melihat kenyataan tersebut $\mathrm{Si} \mathrm{Aku}$ berpikiran untuk memperingatkan dengan sungguh-sungguh agar Si Kamu menghindari wanita. Fakta sejarah membuktikan dan memperkuat persepsi bahwa lelaki berkebangsaan Arab jaman dahulu, pada masa kerasulan Nabi memiliki rasa ketertarikan lebih kuat kepada wanita dalam hal seksual. Hal itu disebabkan Si Aku menyadari sifat Si Kamu sebagai lelaki normal yang juga menyadari keindahan wanita serta daya pikatnya, maka ia benar-benar ingin agar Si Kamu takut untuk bergaul lebih jauh dengan wanita jangan sampai ia terperosok dan terpedaya.

25. Bait ke-29 dan 30:

$$
\text { 29. 29. و الق عدوّك بالتحيّ” }
$$




$$
\text { - }
$$

- Temui musuhmu dengan hormat (dahului dengan penghormatan). Jangan pernah takut selamanya sehingga kamu mendekatinya (takut jikalau dia melawanmu). Perhatikanlah dia (musuhmu) tatkala suatu hari mendatangimu dengan tersenyum. Singa akan menampakkan taringnya lebih dahulu saat marah, (menampakkan gigi tidak selalu berarti senyuman karena seringai singa menandakan dia marah).

Selanjutnya Si Aku memperingatkan agar Si Kamu waspada dengan musuh yang datang dengan mulut manis, menyamar dengan tersenyum serta menampakkan sikap bersahabat. Ia mengibaratkan musuh dengan singa yang menampakkan taringnya tatkala akan menerkam.

Allah memberikan penjelasan mengenai sikap yang harus diambil Nabi tatkala menghadapi musuh dalam beberapa ayat berikut.

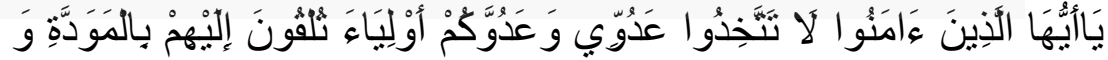

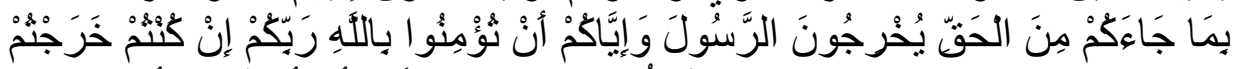

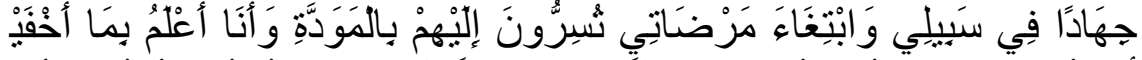

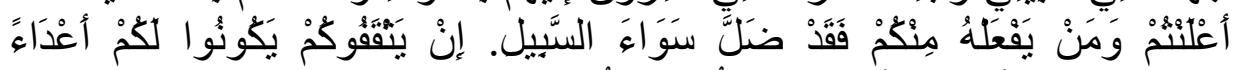

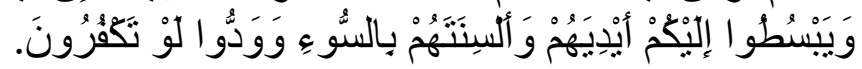

Hai orang-orang yang beriman, janganlah kamu mengambil musuh-Ku dan musuhmu menjadi teman-teman setia yang kamu sampaikan kepada mereka (berita-berita Muhammad), karena rasa kasih sayang; padahal sesungguhnya mereka telah ingkar kepada kebenaran yang datang kepadamu, mereka mengusir Rasul dan (mengusir) kamu karena kamu beriman kepada Allah, Tuhanmu. Jika kamu benar-benar keluar untuk berjihad pada jalan-Ku dan mencari keridhaan-Ku (janganlah kamu berbuat demikian). Kamu memberitahukan secara rahasia (berita-berita Muhammad) kepada mereka, karena rasa kasih sayang. Aku lebih mengetahui apa yang kamu sembunyikan dan apa yang kamu nyatakan. Dan barangsiapa di antara kamu yang melakukannya, maka 
sesungguhnya dia telah tersesat dari jalan yang lurus. Jika mereka menangkap kamu, niscaya mereka bertindak sebagai musuh bagimu dan melepaskan tangan dan lidah mereka kepadamu dengan menyakiti (mu); dan mereka ingin supaya kamu (kembali) kafir (Q.S. Al-Mumtahanah:12).

Berdasar keterangan di atas seorang muslim haruslah tegas dalam menghadapi musuh Islam, yaitu golongan kafir, jangan sampai bersikap lemah dengan mereka terutama masalah agama. Adapun konteks ayat di atas adalah orang kafir pada jaman Nabi. Untuk jaman sekarang hubungan islam dengan kafir (non muslim) cenderung lebih longgar. Selama mereka tidak memerangi dan mengakui keberadaan Islam, maka tidak ada perintah untuk memerangi mereka.

26. Bait ke-31:

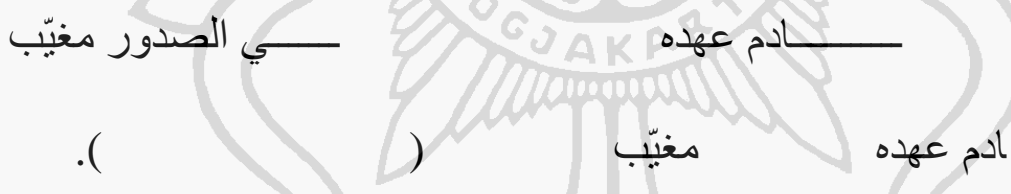

Sesungguhnya pendendam itu meskipun telah berikrar, dendam akan tetap tinggal, tersembunyi di dadanya.

Si Aku memperingatkan untuk mewaspadai pendendam. Menurutnya meskipun Si pendendam telah bersumpah untuk tidak mendendam, belum tentu hatinya telah meninggalkan dendam itu. Hal ini dapat diartikan bahwa dendam seseorang tidak akan mudah hilang. Banyak kasus pembunuhan yang sering terjadi dewasa ini berdasar atas dendam. Hal ini membuktikan bahwa rasa dendam memang sulit dihilangkan.

27. Bait ke-32:

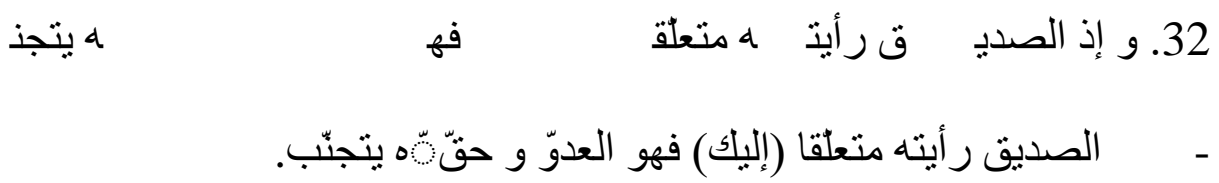


- Jika temanmu kau lihat bergantung padamu, maka dia adalah musuh yang sebenarnya dijauhi.

Si Aku menjelaskan bahwa sahabat yang sering bergantung bukanlah sahabat sesunguhnya, melainkan musuh yang seharusnya dijauhi karena teman yang baik adalah seseorang yang mau saling membantu tanpa pamrih, mau memperingatkan kesalahan, dan tidak hanya dekat di saat senang dan jauh di saat kesusahan. Kehidupan seseorang sangat dipengaruhi oleh lingkungan tempat ia berkembang. Oleh karena itu, memilih sahabat merupakan hal penting.

28 Bait ke-33, 34, 35, dan 36:

ه ينامُ

$$
\text { و أذا توارى عنك فه }
$$

و يروغ منلك كم إيروغ الثعل

إنّ القرين إلى المق ارن بنس
(حلاوة الحديث) و قلبه يتلهّب

( ) (غاب) عنك فه )

( ظهر)

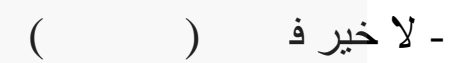

(مليء شـرّا). (الصدديق) يلقاك( ) يحلف أنّهـ بك و اثذ

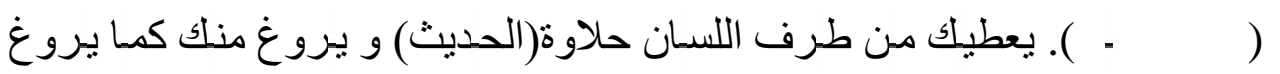

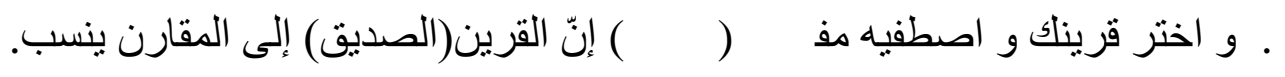

- Tidak ada kebaikan mencintai seeorang yang mengutamakan mulut manis sedangkan hatinya bergejolak, (tidak baik menjadikan teman seorang yang bermulut manis sedangkan hatinya penuh kejahatan). (Temanmu) menemuimu, bersumpah setia padamu. Namun, ketika pergi darimu dia (seperti) kala (beracun). Dari ujung bibirnya ia memberimu (ucapan) manis, kemudian dia membujukmu 
sebagaimana musang. Pilihlah temanmu, ambillah yang terhormat. Sungguh, teman akan digolongkan berdasar temannya.

Empat bait ini menegaskan bagaimana berhubungan dengan teman. Syair dalam bahasa persi menerangkan tentang hikmah pergaulan sebagai berikut, (Az-Zarnuji, tt:23).

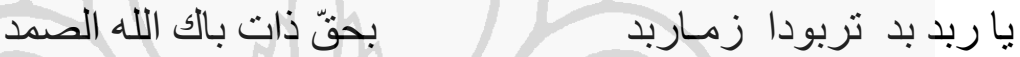

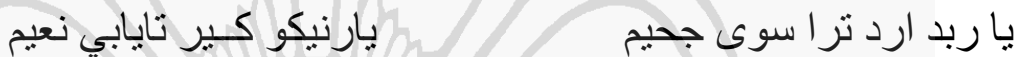

(Ya rabad bad tar buda zamaribad bihaqqi zati bakillahis samad Ya rabid arad tara siwa jahimi ya raniku kira tayabi na'imi)

Sesungguhnya teman yang buruk itu lebih berbahaya dari pada ular jahat, demi Allah Yang Maha Luhur dan Maha Suci.

Sesungguhnya teman yang buruk dan jahat itu dapat menjerumuskan engkau ke dalam neraka Jahannam. Karena itu carilah teman yang baik tingkah lakunya, agar engkau berhasil mendapat surga Na'im.

Syair (Az-Zarnuji, tt:22) yang lain menyatakan.

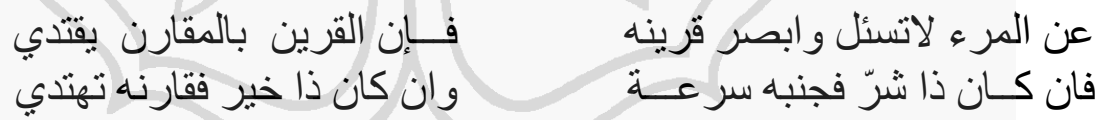

(Anil mar'i la tas'al wabsir qarinahu fa innal qarina bilmaqarini yaqtadi. Fa in kana za syarrin fa jannibhu sur'atan wa in kana za khairin faqarinhu tahtadi)

Jika engkau ingin mengetahui watak seseorang, maka janganlah bertanya kepadanya, tetapi lihatlah dengan siapa ia bergaul. Sebab, di dalam pergaulan itu sering terjadi perilaku seseorang mengikuti temannya.

Jika teman itu berperilaku tidak baik, maka cepat-cepatlah menjauhinya. Jika berperilaku baik, maka bertemanlah dengannya agar kau mendapat petunjuk darinya.

29. Bait ke-37, 38, dan 39:

$$
\text { 38. 37. }
$$




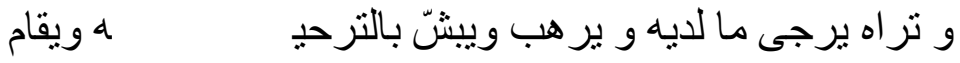

$$
\begin{aligned}
& \text { عند سلامه ويقرب و( - الققر شين(عيب) للرجال فإنّه بزرى بـه الثـهم الأديب الأنسب } \\
& \text { (اي الثهم الأديب العالي التسب يحتقره الناس ) }
\end{aligned}
$$

- Orang kaya dihormati orang-orang. Kamu melihatnya diharap-harapkan untuk dapat disanding dan dia juga ditakuti. Saat ia datang, ia disambut dengan senyum kelapangan serta disambut atas keselamatannya. Adapun orang miskin adalah aib bagi orang-orang. Lantaran fakir, orang cerdas, beradab dan berketurunan baik direndahkan, (orang yang pandai, beradab, dan berketurunan baik akan direndahkan masyarakat jika ia miskin).

Kebanyakan orang memilih untuk berteman dengan orang kaya. Mereka disanjung, dihormati, sedangkan orang miskin dianggap aib bagi masyarakat. Meskipun seseorang berpendidkan tinggi, keturunan terhormat dan terpelajar, tetapi jika ia miskin tetap saja di mata masyarakat umum akan direndahkan.

Allah memerintahkan manusia untuk bergaul, saling mengenal tanpa membeda-bedakan satu sama lain. Allah tidak membeda-bedakan umat-Nya. Bagi-Nya yang paling bertakwalah yang mendapat kedudukan mulia di sisi-Nya. Jadi tingkatan manusia berdasar ketakwaan, bukan ukuran kekayaan. Sebagaimana firman Allah berikut.

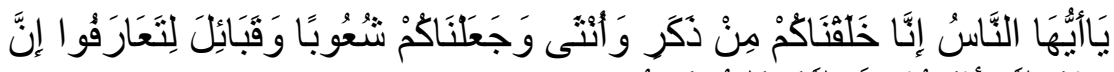

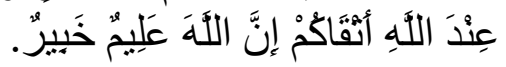

Hai manusia, sesungguhnya Kami menciptakan kamu dari seorang lakilaki dan seorang perempuan dan menjadikan kamu berbangsa-bangsa dan bersuku-suku supaya kamu saling kenal mengenal. Sesungguhnya orang yang paling mulia di antara kamu di sisi Allah ialah orang yang paling bertakwa di antara kamu. Sesungguhnya Allah Maha Mengetahui lagi Maha Mengenal (Q.S. Al-Hujurat: 13). 
Rasulullah pernah menyampaikan bahwa beliau lebih memilih menjadi orang miskin, dan secukupnya saja, meskipun beliau pernah ditawari oleh malaikat Jibril bahwa jika beliau berkenan, maka bukit-bukit Makkah dirubah menjadi emas. Akan tetapi, beliau menolak agar dapat lebih dekat dengan Allah dan lebih menenangkan hati (Nasif, 2003:521).

Nabi juga lebih memilih berteman bersama orang-orang fakir, seperti dalam hadis berikut.

$$
\begin{aligned}
& \text { إنّ أغبط أوليائي عندي لمؤمن خفيف الحاد ذو حظ من الصلاة أحسن عبادة ربّه و }
\end{aligned}
$$

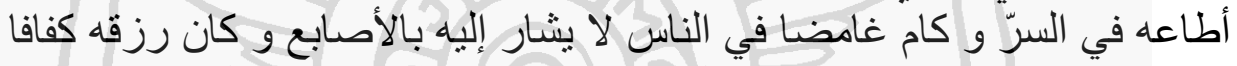

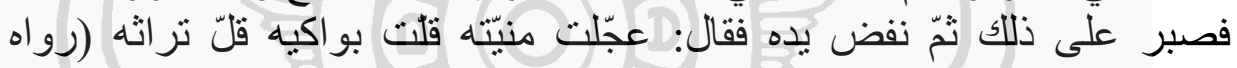

Sesungguhnya orang yang palimg ku kasihi di sisiku adalah seorang mukmin yang keadaannya serba minim, tetapi rajin mengerjakan salat (sunat); dia baik dalam beribadah kepada Rabbnya dan selalu taat kepada-Nya secara diam-diam, serta tidak dikenal di kalangan orang banyak dan bukan termasuk orang yang termasyhur. Rizkinya paspasan, tetapi ia bersabar dengan hal tersebut. Kemudian Nabi Saw menepiskan tangannya seraya bersabda,"Maut datang lebih cepat menjemputnya, sedikit orang yang menangisi, sedikit pula harta peninggalannya (Riwayat At-Turmudzi).

Penjelasan di atas cukup untuk menjadi bahan pertimbangan dalam menjalani kehidupan. Nabi, yang merupakan panutan seluruh umat telah mencontohkan bagaimana bergaul yang baik, yaitu tidak membedakan teman karena faktor kaya dan miskin, berpangkat atau tidak, dan seterusnya. Orang beriman hendaknya saling membaur dan bersatu sebagai umat yang bersaudara.

30. Bait ke-40

$$
\text { - 40. }
$$


- Rendahkan sayapmu terhadap seluruh kerabat dengan merendahkan diri, dan berilah mereka toleransi jika berbuat dosa, (lemah lembutlah kepada para kerabat, bersikaplah sopan, dan bertoleransilah terhadap orang-orang yang melakukan kesalahan).

(wakhfid janahaka), "Merendahkan sayap" merupakan ungkapan untuk memberikan penghormatan. Sayap dapat diartikan sebagai lambang kekuasaan, kedudukan. SiR Aku menganjurkan Si Kamu agar mengabaikan pangkat dan kedudukannya di hadapan sahabat dan keluarga, bersikap lembut dan pemaaf meskipun ia berkedudukan tinggi. Dalam Alqur'an disebutkan sebagai berikut.

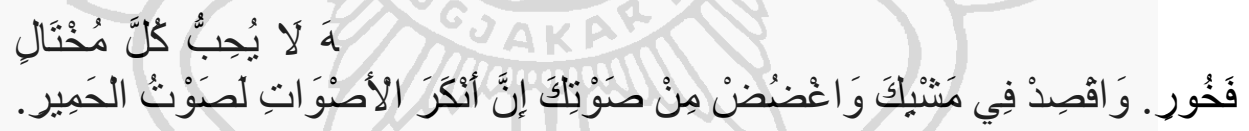
Dan janganlah kamu memalingkan mukamu dari manusia (karena sombong), dan janganlah kamu berjalan di muka bumi dengan angkuh. Sesungguhnya Allah tidak menyukai orang-orang yang sombong lagi membanggakan diri. Dan sederhanalah kamu dalam berjalan dan lunakkanlah suaramu. Sesungguhnya seburuk-buruk suara ialah suara keledai (Q. S. Luqman:18-19).

Bait ini juga berarti larangan agar tidak berlaku sombong. Sombong berarti memandang dirinya memiliki suatu kelebihan di atas orang lain, seperti misalnya kesempurnaan, ilmu, kedudukan, dan kebaikan yang lebih dari pada orang lain. Hal ini merupakan penyakit qalbu yang merusak pelakunya dan menyebabkan memperoleh murka Allah dan kebencian orang-orang, sikap terpuji bagi seseorang adalah berlaku rendah diri karena adakalanya orang yang menurutnya lebih rendah darinya di sisi Allah lebih baik daripadanya (Nasif, 2003:95-97). 
Takabbur merupakan sifat yang hanya khusus bagi Allah Swt. Tidak boleh seorang pun dari makhluk-Nya menyandang kedua sifat tersebut atau salah satunya. Barang siapa yang menduga bahwa dirinya pantas menyandang kedua sifat itu, maka Allah akan mencampakkannya ke dalam neraka karena ia telah melampaui batas sebagai hamba-Nya yang seharusnya bersifat rendah diri dan hina di hadapan-Nya (Nasif, 2003:95-97).

Hadis Ibn Asakir berkaitan dengan sombong dan iri hati seperti berikut, "Hati-hatilah terhadap sikap sombong karena sifat sombonglah yang mendorong iblis tidak mau bersujud kepada Nabi Adam. Hati-hatilah kalian dari keinginan yang menggebu-gebu karena hal inilah yang menyebabkan Nabi Adam memakan buah pohon terlarang. Hati-hatilah kalian terhadap sifat iri karena kedua anak Adam membunuh salah seorang di antaranya hanyalah karena terdorong sifat iri hati; sifat ini merupakan biang dari segala perbuatan dosa” (Nasif, 2003:95-97).

31. Bait ke-41 dan 42:

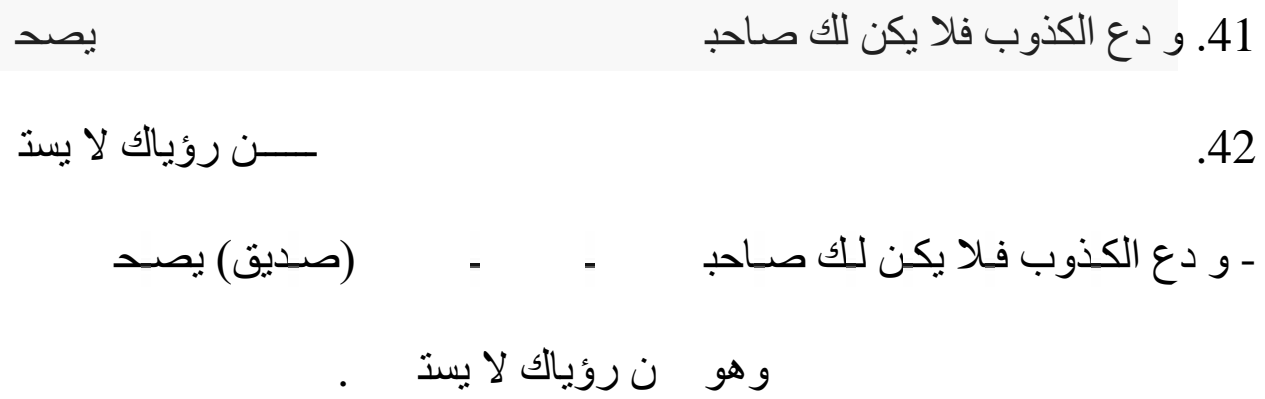

- Jauhi pembohong, jangan sampai ia menjadi temanmu. Sungguh pembohong adalah seburuk-buruk teman untuk dipergauli, dan waspadalah terhadap pendengki, meskipun ia hanya sekali bersamamu. Jauhilah dia. Ia akan sulit hilang dari pandangan matamu. 
Si Aku menegaskan kembali untuk berhati-hati dalam memilih teman. Ia mencegah Si Kamu agar jangan sampai menjadikan pembohong dan pendengki sebagai teman.

Keterangan mengenai jeleknya orang yang bersifat iri dengki dapat dilihat pada bait sebelumya, sedangkan pendusta merupakan sifat yang dibenci Allah dan Rasul-Nya. Apalagi jika ia bersumpah palsu dengan menyebut nama Allah, hal itu berarti menyesatkan dan menghina Asma Allah.

Pembohong, sebagaimana diterangkan hadis sahih Ibnu Umar yang diriwayatkan At-Turmudzi menyatakan bahwasanya pembohong akan dijauhi oleh malaikat sejauh satu mil karena bau busuk yang ditimbulkanya (Nasif, 2003:133). Oleh karena itu, sangat jelek berteman dengan orang yang bersifat seperti tersebut.

32. Bait ke-43 dan 44:
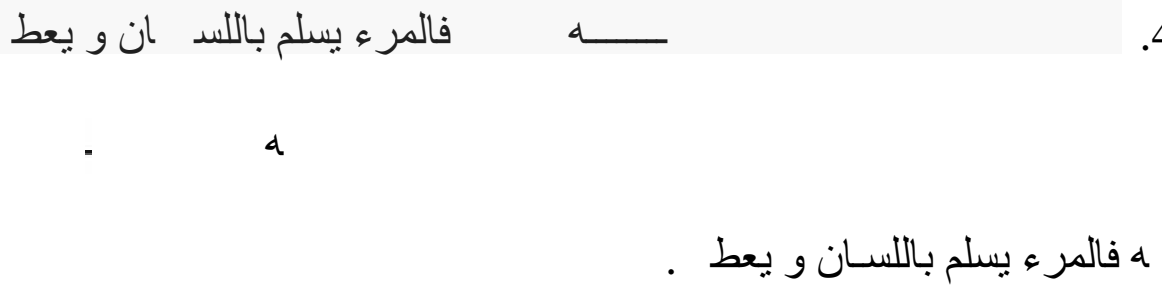

- Pertimbangkanlah kata-katamu saat kamu berbicara. Jangan seperti mata air yang berlimpah, berceloteh (banyak bicara) di setiap seruanmu. Jaga lisanmu. Perhatikan tiap kata-katanya. Seseorang akan selamat atau pun terjerumus karena lisannya.

Bagian ini menerangkan tentang tata cara berbicara yang baik. Si Aku memberi ibarat dengan ثرثـارة “sarsaratan”, "mata air yang berlimpah", 
maksudnya tidak baik jika seseorang berbicara terlalu panjang lebar. Semakin banyak seseorang berbicara tentu semakin banyak salah dan dosa yang ditimbulkannya. Sebaliknya semakin sedikit seseorang berbicara ia akan semakin terjaga. Tentu saja hal ini dikontekskan dengan keadaan di mana seseorang memang tidak dituntut untuk berbicara banyak.

Si Aku menambahkan bahwa seseorang harus berhati-hati dalam menyusun tiap ucapan, karena keselamatan seseorang terletak dari kemampuannya menjaga lisan. Syair Imam Ali yang lain menyatakan sebagai berikut (Az-Zarnuji, TT:112).

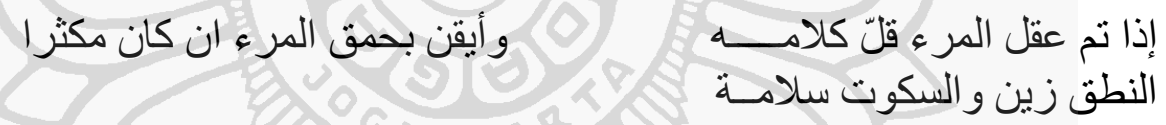

(iza tamma aqlul mar ` qalla kalamuhu wa aiqin bi humqil mar $i$ in kana muksira. Annutqu zainun was sukutu salamatun faiza nataqta fa la takun miksara. Ma in nadimta 'alas sukuti marratan wa laqad nadimta 'alal kalami miraran).

Kalau seseorang itu sempurna akalnya, pasti sedikit bicaranya; yakinlah bahwa orang yang banyak bicaranya adalah orang yang kosong (bodoh).

Ucapan itu menjadi hiasan seseorang, diam adalah selamat: jika engkau biara, maka janganlah terlalu banyak, tapi cukuplah yang perlu-perlu saja.

Engkau tidak akan kecewa dengan diammu, meskipun hanya sekali: tetapi justru engkau akan kecewa karena bicaramu yang berulangulang.

Menjaga lisan sangatlah penting. Diibaratkan bahwa kaki yang terpeleset mudah diobati. Akan tetapi, jika lisan yang terpeleset nyawa bisa melayang. Oleh karena itu, untuk menghindari berbicara yang tidak baik, maka lebih baik diam. Hendaklah orang mukmin berkata yang baik-baik saja karena perkataan yang baik merupakan sadaqah. Sebagaimana hadis yang diriwayatkan Abu Hurairah berikut 


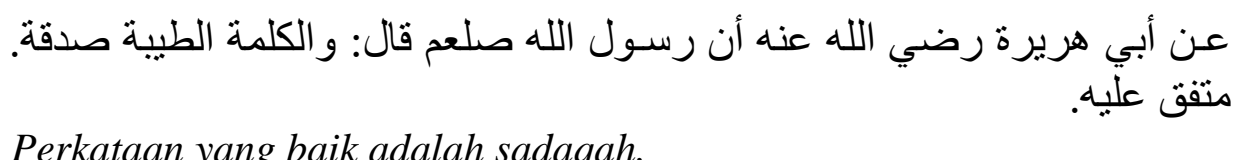
Perkataan yang baik adalah sadaqah.

33. Bait ke-45:

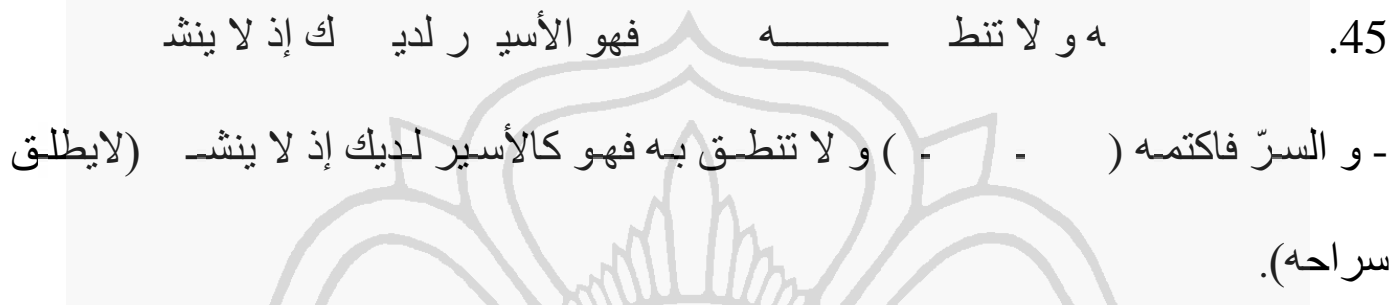

- Jagalah rahasia dan jangan membicarakannya. Hal itu seperti tawanan di sampingmu, meski tidak terlibat, (simpanlah rahasia jangan utarakan, rahasia itu bagaikan tawanan di sampingmu, tidak boleh dibocorkan rahasianya).

Menjaga Amanat merupakan perkara wajib, sebagaimana yang ditegaskan Allah dalam firman-Nya berikut.

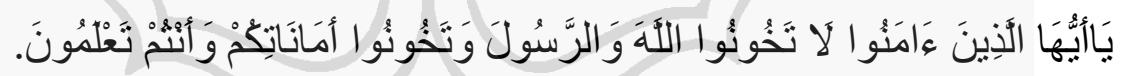

Hai orang-orang yang beriman, janganlah kamu mengkhianati Allah dan Rasul (Muhammad) dan (juga) janganlah kamu mengkhianati amanat-amanat yang dipercayakan kepadamu, sedang kamu mengetahui (Q. S. Al-Anfal: 27).

Si Aku menegaskan bahwa seorang muslim haruslah menjaga amanat. Salah satu contohnya adalah rahasia. Pantang bagi muslim sejati untuk membocorkan rahasia meskipun nyawa taruhannya. Rahasia diibaratkan sebagai tawanan yang meminta perlindungan, adalah wajib hukumnya bagi orang yang diberi amanat untuk menjaganya. Sebaliknya orang yang membocorkan rahasia berarti telah mengingkari amanat, dan termasuk golongan orang munafik. Sebuah hadis dari Abu Hurairah menyatakan tentang ciri-ciri orang munafik sebagai berikut. 
عن أبي هريرة رضي الله عنه أن رسـول الله صلعم قال: أية المنافق ثناث إذا

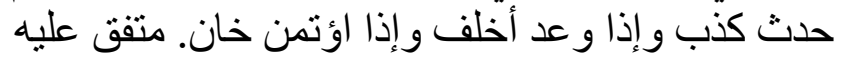

Tanda-tanda orang munafik ada tiga; jika berbicara ia berdusta, jika bersumpah ia mengingkari, dan jika dipercaya ia berkhianat.

Adapun orang munafik mendapatkan ancaman sebagai penghuni neraka yang paling dasar.

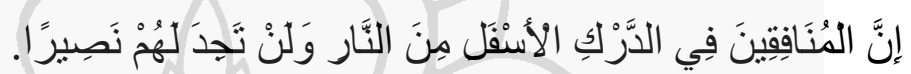
Sesungguhnya orang-orang munafik itu (ditempatkan) pada tingkatan yang paling bawah dari neraka. Dan kamu sekali-kali tidak akan mendapat seorang penolongpun bagi mereka (Q. S. An-Nisa: 145).

Dari penjelasan bait di atas, orang beriman haruslah memenuhi amanat, menjauhi khianat dan sifat munafik lainnya agar hubungan sesama umat Islam dapat berjalan dengan baik.

34. Bait ke-46 dan 47:

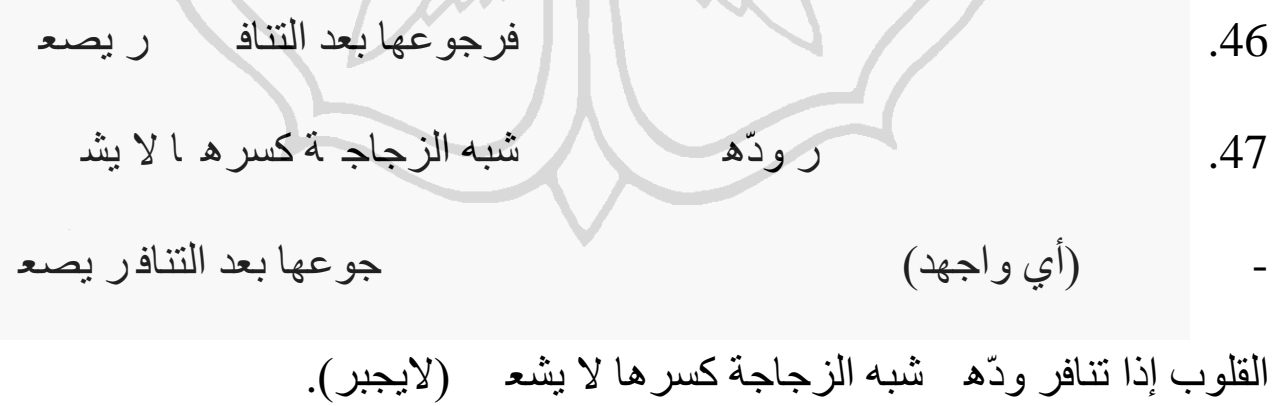

- Bersungguhlah dalam menjaga hati dari penyakit karena mengembalikannya setelah berubah sangatlah sulit. Sesungguhnya hati itu jika cintanya telah berubah menjadi benci, akan menyerupai kaca, pecahannya tak dapat disatukan.

Bait ini merupakan anjuran untuk menjaga hati dari berbagai penyakit. Penyakit hati sangat banyak, seperti adu domba, meggunjing, iri, dengki, sombong dan lain sebagainya sampai yang terberat adalah syirik. Banyak akhlak 
tercela yang berawal dari hati yang jahat. Sebaliknya akhlak baik timbul karena hati yang baik pula.

Menurut Si Aku hati ibarat kaca, apabila retak, maka tidak akan mungkin dapat disatukan seperti sedia kala. Hati sangat sulit dikembalikan menjadi baik bila telah penuh dengan penyakit. Hati yang layaknya kaca sebagai tempat bercermin tidak akan bisa difungsikan jika penuh noda. Kaca tersebut dapat kembali digunakan untuk bercermin, jika noda yang menutupi permukaannya dibersihkan. Begitu juga hati akan kembali jernih, jika tiap kali terkena noda segera dibersihkan dengan istigfar dan mengerjakan amal saleh.

35. Bait ke-48:

$$
\begin{aligned}
& \text { 48. و كذالك سرّ المرء إن لم يط ل A C R RA السنة تزي } \\
& \text { - و كذاك سرّ المرء إن لم بط لـنشرثه السنة نزي }
\end{aligned}
$$

Begitupula rahasia seseorang, apabila dia tidak menyembunyikannya, maka mulut-mulut akan menyebarkan, menambah dan mendustakannya.

Bait ini menerangkan bahwasanya seseorang yang memegang rahasia hendaklah berhati-hati dalam menjaga lisannya. Jika ia tidak pandai-pandai menjaganya tentulah rahasia itu akan cepat tersebar. Rahasia yang telah melewati banyak orang, banyak mulut akan menjadi semakin bertambah.

Informasi dapat berubah setelah melewati banyak orang. Begitu juga rahasia, apabila disampaikan seseorang kepada orang lain akan menjadi berkembang dan bisa berubah dari fakta aslinya.

36. Bait ke-49, 50, dan 51:

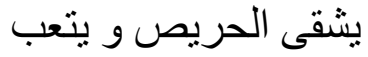

49. لا تحرصنّ فالحرص ليس بزاءُ 


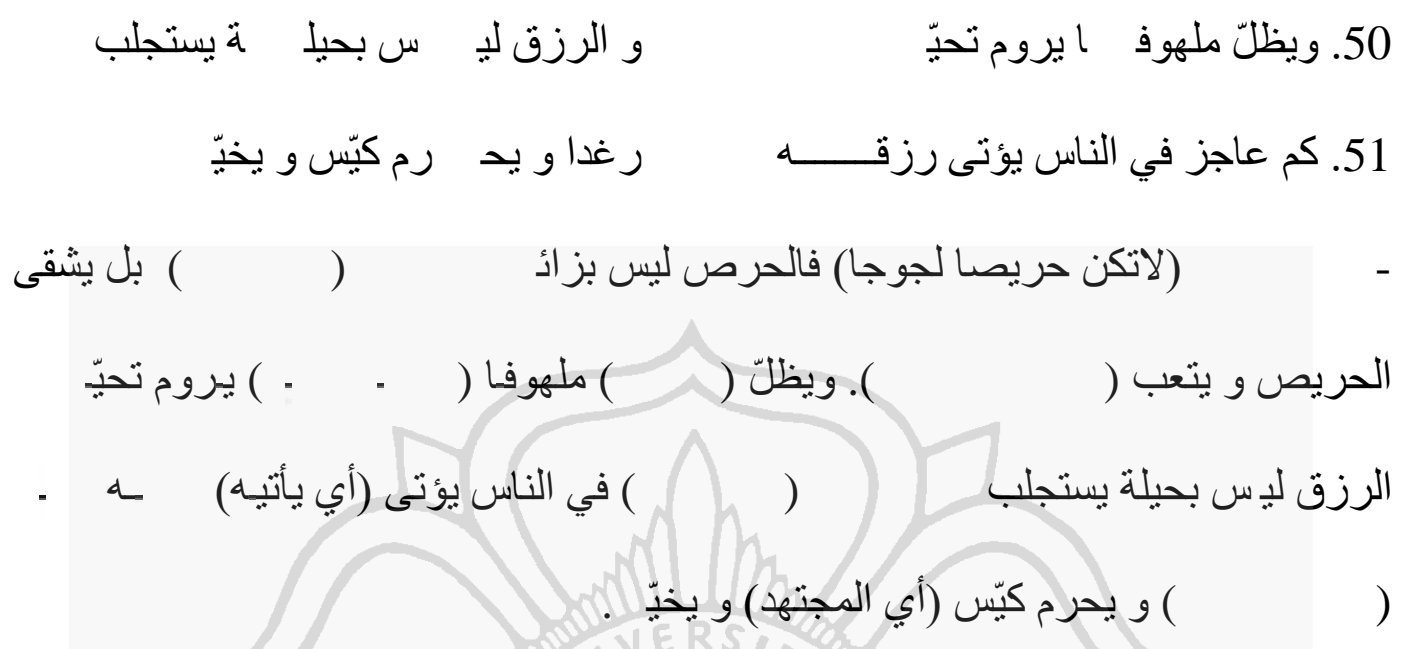

- Jangan tamak (jangan menjadi orang tamak yang keras kepala). Tamak tidak menambah rizki, bahkan mencelakakan dan menyusahkan. Orang tamak akan terus dibayangi khayalan, sedangkan rizki tidak diperoleh dengan tipu daya. Banyak orang lemah (tak mampu bekerja) yang dilapangkan rizkinya, dan orang mampu (orang yang bekerja keras) terhalang rizkinya dan terkecewakan.

Dalam berusaha hendaknya seseorang tidak tamak, justru ketamakan akan mempersulit kehidupannya. Orang tamak tidak akan merasa puas dengan apa yang telah diperoleh. Ia terus berpikir bagaimana menambah rizkinya. Menurut $\mathrm{Si}$ Aku orang tamak lebih banyak berkhayal, mengkhayalkan cara-cara meperoleh rizki, sedangkan rizki tidak dapat diperoleh hanya dengan berkhayal, melainkan dengan bekerja.

Rizki merupakan anugrah yang digariskan Allah. Sebesar apapun usaha yang telah dilakukan seseorang, bisa saja ia tidak mendapatkan apa-apa jika Allah menhendaki. Sebaliknya Allah Maha Kuasa memberi rizki terhadap orang yang dikehendaki-Nya meskipun orang tersebut tidak terlihat berusaha atau bekerja. Terdapat sebuah hadis yang diriwayatkan sahabat Anas R.a. menerangkan 
bahwasannya rizki manusia telah ditetapkan sejak manusia masih berupa janin dalam rahim.

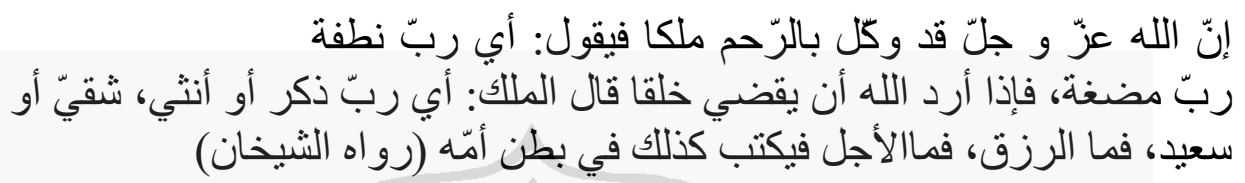
Sesungguhnya Allah Swt telah memerintahkan kepada seorang malaikat untuk menangani rahim, lalu malaikat itu berkata," Wahai Rabbku, ini air mani. Hai rabbku, ini 'alaqah. Hai Rabbku, ini segumpal daging." Apabila allah hendak menentukan bentuk, malaikat itu berkata," Wahai rabbku, apakah laki-laki atau perempuan; celaka atau bahagiakah, berapakah rizqinya; dan sampai kapan ajalnya?" Hal terebut di catat sejak berada di dalam rahim ibunya.

Rizki juga merupakan hal duniawi yang digunakan Allah untuk menguji hamba-Nya, bagaimanakah rizki itu disikapi oleh hamba-Nya. Keimanan merupakan hal yang sangat sulit. Adapun orang yang meyakini bahwa rizki semata-mata dari Allah hanyalah orang yang beriman kuat. Pada tingkatan tertentu, orang beriman tidak terlalu memikirkan masalah rizki. Ia tetap berusaha, tetapi memasrahkan apapun yang didapatnya kepada Allah semata karena yang dinilai Allah adalah usaha hamba-Nya bukan hasilnya. Ia tidak pernah kahawatir akan rizqinya dari Allah. Firman Allah menyebutkan sebagai berikut.

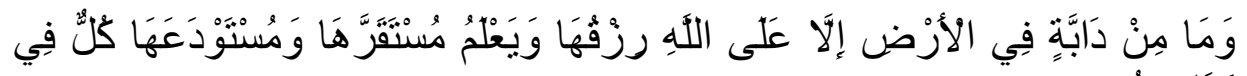
كِتَابٍ مُبينِ. Dan tidak ada suatu binatang melatapun di bumi melainkan Allah-lah yang memberi rizkinya, dan Dia mengetahui tempat berdiam binatang itu dan tempat penyimpanannya. Semuanya tertulis dalam kitab yang nyata (Lauh Mahfuzh) (Q. S. Hud: 6).

Dalam kehidupan sehari-hari banyak dijumpai bahwasanya banyak orang-orang beriman yang hidup kekurangan. Sebaliknya orang-orang non muslim mendapatkan kehidupan layak, bahkan berlimpah. Orang yang berpegang 
teguh pada kebenaran terus hidup dalam kemiskinan, sedang para koruptor terus bertambah makmur.

Hikmah dan saripati dari bait ini dimungkinkan berkaitan dengan barakah, sebagaimana yang diungkapkan dalam bait keduapuluh tiga yang berbicara tentang qana'ah. Harta yang melimpah, pangkat dan jabatan tinggi bukanlah jaminan kebahagiaan. Sebaliknya kehidupan yang tampak lahirnya kekurangan malah menimbulkan sikap ikhlas dan tentram.

Si Aku menyatakan bahwa orang-orang mampu akan terhalang dan terkecewakan. Kalimat ini dapat diartikan bahwa mereka terhalang dari rahmat Allah. Allah menguji mereka dengan nikmat yang banyak dan mereka tidak menyadari bahwa nikmat juga merupakan cobaan. Kemudian Allah menambah lagi nikmatnya dan mereka semakin melupakan Allah. Hati mereka telah dipenuhi dengan kepentingan-kepentingan duniawi, tak ada ruang lagi untuk berdzikir kepada Allah. Kelak di akhirat mereka akan menyesal dan kecewa dengan perbuatan mereka di dunia. Mereka tertipu dengan nikmat yang Allah berikan. Mereka gagal menghadapi ujian.

37. Bait ke-52 dan 53:

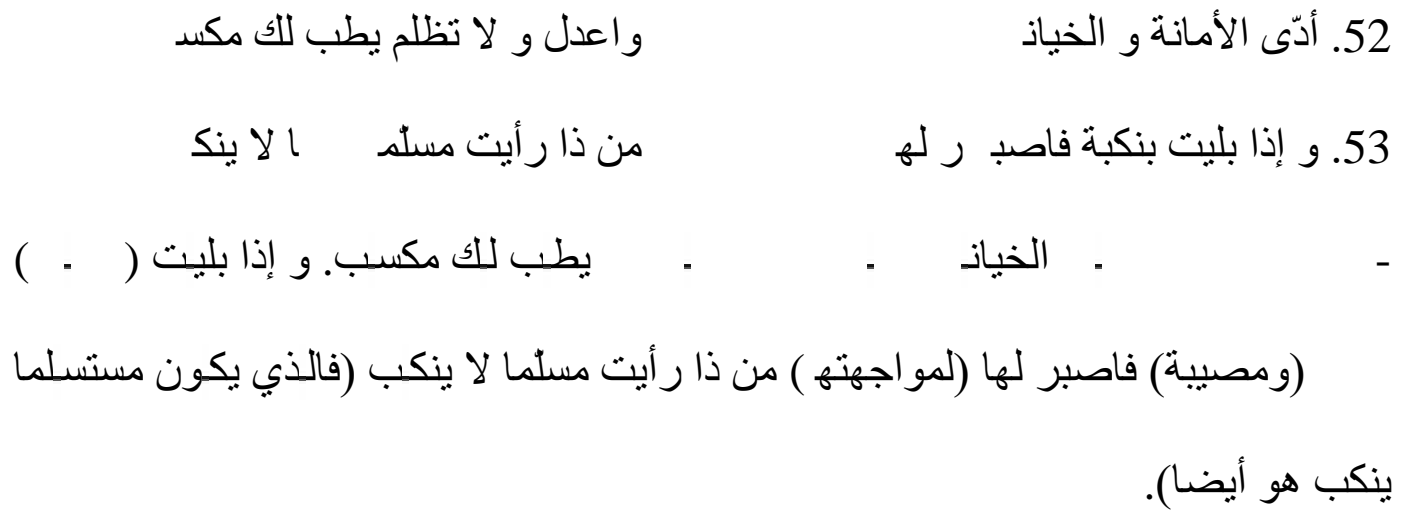


- Penuhilah amanat dan jauhi khianat. Berbuatlah adil jangan dzalim, niscaya usahamu akan beroleh kebajikan. Bersabarlah jika kau tertimpa bencana dan musibah, ia juga menimpa orang yang kau anggap selamat (musibah juga menimpa selain kamu).

Bagian ini menerangkan bahwa dalam berikhtiar, berusaha mencari rizki hendaklah tetap berpegang pada koridor hukum Islam yang benar. Seperti menjaga amanat dalam perniagaan. Nabi Muhammad merupakan contoh yang jelas. Saat beliau belum diangkat menjadi Nabi beliau sudah dikenal dengan sebutan al Amin, orang yang dapat dipercaya. Dalam berdagang beliau terkenal jujur, tidak mengurangkan timbangan dan bersih. Ia menjalankan usaha sesuai dengan yang diamanatkan tuannya. Kemudian Allah melimpahkan rizki yang banyak kepadanya. Barang dagangan beliau selalu habis terjual dan memperoleh banyak untung dalam waktu singkat.

Dalam berusaha hendaknya tidak berbuat khianat. Mungkin dengan menipu akan mendapatkan untung besar, tetapi jika pengkhianatan dan kebohongan terungkap, maka orang tersebut justru akan memperoleh kerugian besar. Ia tidak akan mendapat banyak teman, kecuali orang-orang yang memang suka menjilat dan mencari keuntungan dari orang lain. Adapun ancaman Allah telah jelas, yaitu bagi mereka, orang munafik disediakan tempat di dasar neraka.

Selanjutnya dalam berusaha juga harus berlaku adil dan tidak dzalim. Laba ataupun rugi merupakan ketentuan Allah. Sepandai apapun manusia mengkalkulasi untung dan rugi, Allah lebih berkuasa menentukan hasilnya. Hendaknya seseorang tidak hanya memikirkan untung rugi. Akan tetapi, ia juga 
harus memikirkan kebajikan yang diperoleh dari usahanya, bagaimana memperoleh kerelaan Allah dalam usahanya. Jika demikian, niscaya ia memperoleh kebajikan di dunia dan akhirat.

Jika nikmat pada hakikatnya merupakan ujian, maka bencana juga ujian dari Allah. Allah Maha kuasa menimpakan nikmat ataupun bencana kepada hamba-hamba-Nya. Si Aku menyarankan untuk tidak memandang bencana sebagai hal yang ditakuti. Bencana datang untuk dihadapi, disikapi dengan bijaksana dan sabar, selanjutnya dijadikan bahan untuk berpikir.

Bencana tidak menimpa kepada orang kesusahan saja, tetapi juga orang yang kecukupan. Hanya saja banyak orang menganggap bahwa orang yang berkecukupan tidak mungkin tertimpa bencana. Bagi Allah sangat mudah merubah keadaan hamba-hamba-Nya. Namun, tidak seorangpun tahu akan kehendak-Nya. Hanya Dia yang Maha Bijaksana.

Allah mencintai hamba-Nya yang mendekatkan diri kepada-Nya. Faktanya dapat diketahui bahwa orang yang hidup kesusahan dan kekurangan akan lebih sering dan lebih mudah mendekatkan diri kepada-Nya dibanding orang-orang yang bergelimang harta. Orang miskin punya lebih banyak waktu luang untuk beribadah, mendekat kepada Allah, di saat orang-orang kaya masih sibuk menghitung laba rugi usahanya. Namun, sangat sedikit orang yang sabar menerima kemiskinan sebagai nikmat dari Allah.

38. Bait ke-54 dan 55:

$$
\text { 55. }
$$




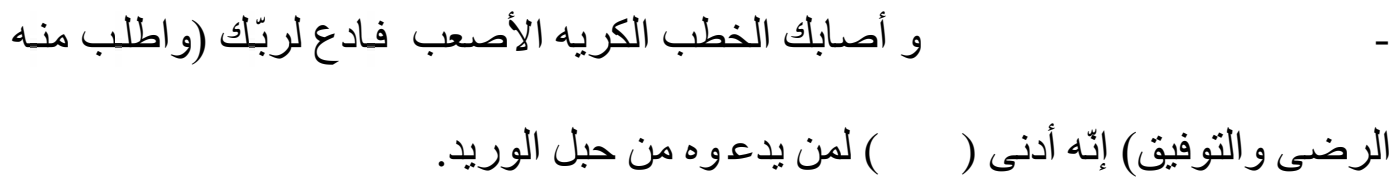

- Jika dalam hidupmu kau terkena kesulitan juga hal yang rumit dan kau benci, maka berdoalah kepada Tuhanmu. Sungguh Ia lebih dekat daripada urat leher bagi orang yang memanggil-Nya.

$\mathrm{Si} \mathrm{Aku}$ menjelaskan sikap yang harus ditempuh tatkala seseorang tertimpa kesulitan. Orang beriman seharusnya mengembalikan segala sesuatu kepada Allah. Ia akan bersyukur dan berdzikir di saat kecukupan maupun kekurangan, di saat mendapat nikmat ataupun tertimpa bencana.

Di saat kesulitan yang dihadapi telah memuncak, Si Aku menyarankan untuk mengadu hanya kepada Allah. Dialah satu-satunya tempat mengadu. Berdoa merupakan perintah Alah, hukumnya wajib. Setiap perkara wajib akan diikuti pahala jika dilaksanakan. Orang yang taat dan bertakwa akan menjalankan perintah Allah semata-mata mengharap ridla-Nya. Mereka menjalankan perintah Allah sebagai kebutuhan pribadinya, bukan lagi karena ancaman neraka dan pahala surga.

Allah Maha Mendengar. Allah lebih dekat daripada urat leher bagi orang yang menyeru-Nya. Oleh karena itu, tepatlah jika hanya Allah sepatut-patut tempat mengadu. Allah Maha Kaya atas segala permohonan hamba-Nya. Allah menyebutkan dalam firman-Nya sebagai berikut.

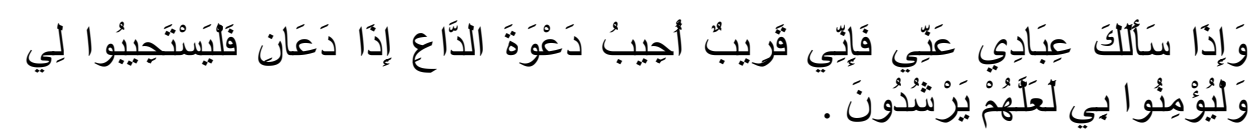

Dan apabila hamba-hamba-Ku bertanya kepadamu tentang Aku, maka (jawablah), bahwasanya Aku adalah dekat. Aku mengabulkan permohonan orang yang berdoa apabila ia memohon kepada-Ku, maka 
hendaklah mereka itu memenuhi (segala perintah)Ku dan hendaklah mereka beriman kepada-Ku, agar mereka selalu berada dalam kebenaran (Q.S. al-Baqarah: 186).

Berdasar penjelasan bait di atas, orang beriman hendaklah mengembalikan semua permasalahan kepada Allah. Manusia yang berikhtiar dan Allah yang menentukan. Manusia juga harus menyikapi cobaan dan bencana yang diberikan Allah dengan bijaksana.

39. Bait ke-56:

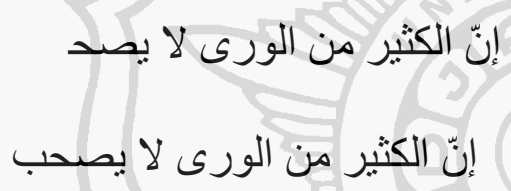

- Carilah tempat di hadapan orang-orang semampumu, karena banyak orang tidak ditemani (tidak mempunyai teman).

Bait ini dapat berarti bahwa seseorang haruslah menjadi diri sendiri. Tampil apa adanya, tidak memaksakan diri menjadi seseorang yang jauh di luar kemampuanya. Bukan berarti seseorang tidak mempunyai ambisi dan cita-cita untuk maju, tetapi bersikap apa adanya jauh lebih mudah dan aman daripada penampilan yang menipu, mengada-ada dan memaksakan diri agar terlilhat lebih dari apa yang sebenarnya.

40. Bait ke-57:

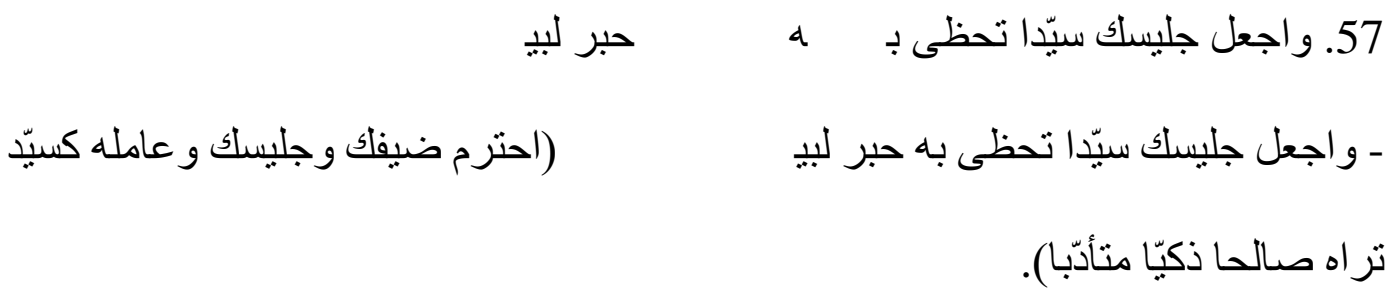


- Anggaplah tamumu sebagai tuan yang kau hormati, sebagai pendeta, orang pandai, berakal, dan berpendidikan (mulyakan tamu dan teman dudukmu, perlakukan sepeti halnya seorang tuan, orang saleh, cerdas, dan beradab).

Bait ini merupakan himbauan untuk memuliakan tamu. Tamu haruslah dihormati. Si Aku mengibaratkan agar memandang tamu sebagai - (habrun) 'pendeta, uskup', orang pandai atau berpendidikan tinggi. Selayaknya seseorang bersikap sopan kepada orang-orang tersebut. Di bait ini Si Aku mengajarkan untuk menganggap setiap tamu sebagai orang yang dimuliakan. Sebagai gambaran memuliakan tamu, ayat berikut dapat diperhatikan.

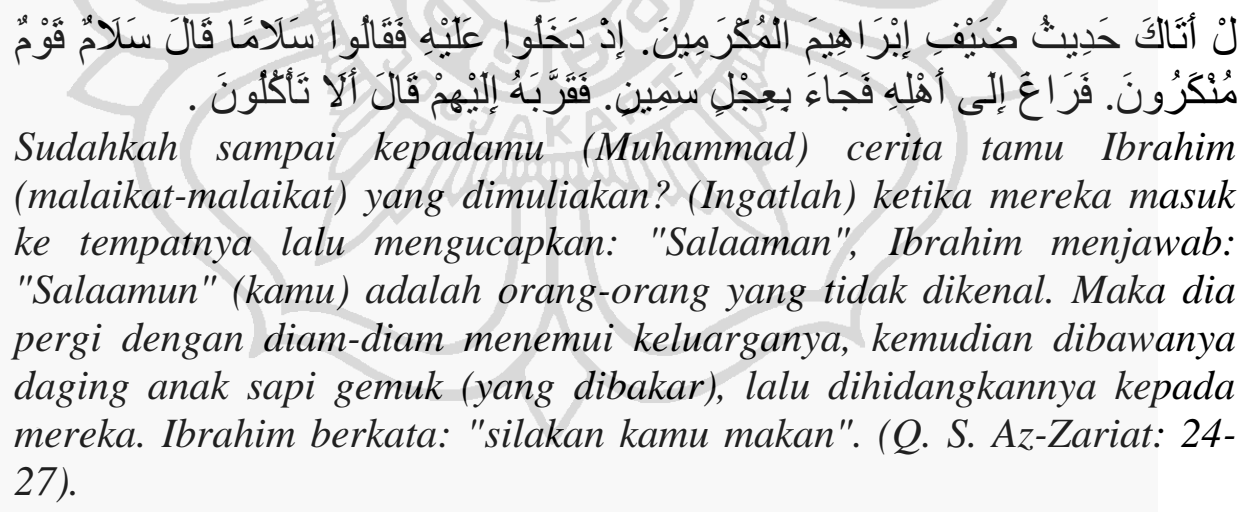

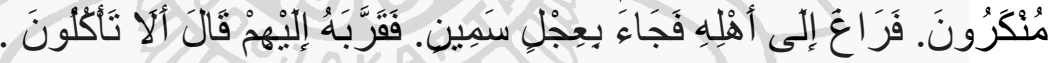
Sudahkah sampai kepadamu (Muhammad) cerita tamu Ibrahim (malaikat-malaikat) yang dimuliakan? (Ingatlah) ketika mereka masuk ke tempatnya lalu mengucapkan: "Salaaman", Ibrahim menjawab: "Salaamun" (kamu) adalah orang-orang yang tidak dikenal. Maka dia pergi dengan diam-diam menemui keluarganya, kemudian dibawanya daging anak sapi gemuk (yang dibakar), lalu dihidangkannya kepada mereka. Ibrahim berkata: "silakan kamu makan". (Q. S. Az-Zariat: 2427).

Tamu merupakan orang yang menyambung silaturrahmi dengan tuan rumah. Nabi sangat menganjurkan untuk menyambung silaturrahmi. Dengannya niscaya hubungan persaudaraan akan terus terjalin, dan memuliakan tamu merupakan jalan dibukanya pintu rizki. Rasulullah bersabda (Yahya, 1994:150).

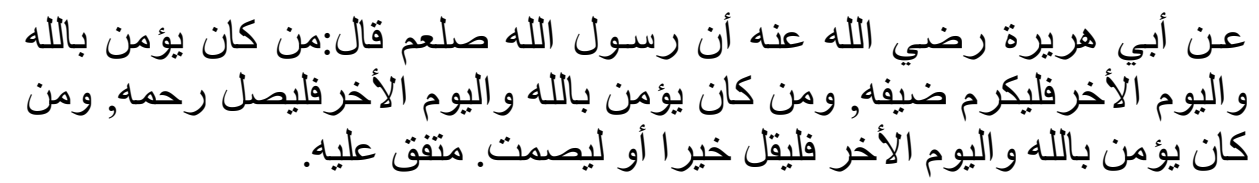

Diriwayatkan dari Abi Hurairah, Nabi bersabda:” Barangsiapa yang beriman kepada Allah dan hari akhir hendaklah memuliakan tamunya. Barangsiapa yang beriman kepada Allah dan hari akhir hendaklah bersilaturrahmi. Barangsiapa yang beriman kepada Allah dan hari akhir hendaklah berkata yang baik atau diam. 
41. Bait ke-58:

$$
\begin{aligned}
& \text { أهه لا بحج } \\
& \text { 58. و احذر من المظلوم سهما صائب } \\
& \text { - و احذر من المظلوم سهما صائب و اعلم بأنّ دعاءه لا يحج . }
\end{aligned}
$$

- Waspadalah terhadap orang yang terdzalimi, yang banyak tertimpa musibah. Ketahuilah bahwa doanya tidak terhijab.

Orang yang terdzalimi mendapatkan posisi yang istimewa di sisi Allah. Pada posisi ini mereka cenderung lebih mendekatkan diri kepada Allah, sedangkan bagi orang-orang yang dekat dengan Allah niscaya Allah juga akan dekat dengannya. Diriwayatkan dalam hadis bahwasanya doa orang terdzalimi tidak terhijab, dalam arti mudah dikabulkan Allah.

Oleh karena itu, Si Aku memperingatkan Si Kamu agar berhati-hati terhadap orang yang terdzalimi. Jangan sampai menambah beban dan derita mereka. Jangan sampai mereka marah kepada Si Kamu. Jika mereka murka niscaya Allah juga murka. Kemudian Si Kamu akan tergolong orang yang celaka.

Sebaliknya Si Kamu haruslah membantu meringankan beban yang mereka tanggung. Terlebih jika orang-orang terebut sama-sama muslim. Alangkah indah jika tiap orang saling tolong menolong, niscaya beban yang ditanggung akan terasa ringan.

42. Bait ke-59 dan 60:

$$
\text { 60. }
$$




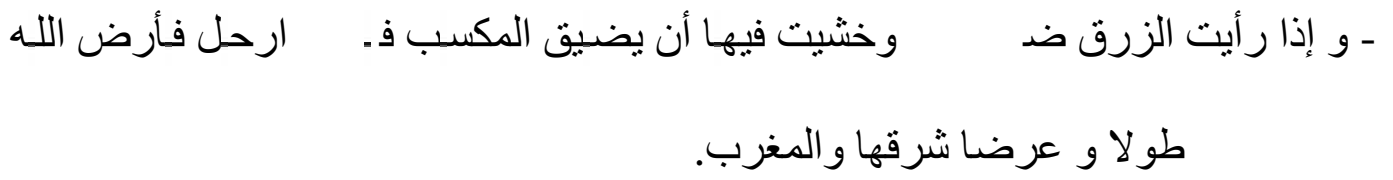

- Jika kamu rasa rizki di suatu negeri terbatas (sempit), dan kamu takut kesempatan kerja didalamnya sempit, maka pergilah. Bumi Allah penuh kelapangan baik panjang, lebar, timur maupun baratnya.

Dua bait ini merupakan anjuran untuk berhijrah, merantau. Bumi Allah terlampau luas untuk dituju. Lahan rizki Allah tak akan pernah surut digali. Allah Maha Kaya. Dengan merantau nalar dan mental seseorang akan jauh lebih berkembang, tahan uji, dan tidak mudah menyerah. Banyak sekali teladan yang mencontohkan sikap ini, mulai dari para nabi, wali, hingga salafuna as salih.

Imam Syafi'i dalam sebuah syairnya menerangkan beberapa keutamaan berhijrah, merantau sebagai berikut (al-Baqa'i, 1988:57).

\section{معبشنة}

همّم

(Tagarab 'anil autani fi talabil ula wa safir fafil asfari khamsu fawaidi Tafarruju hammin, waktisabu ma'isyatin wa 'ilmin wa adabin wa suhbati majidin).

Pergilah (mengasingkan diri) dari kota untuk mencapai keluhuran dan pegilah karena di dalamnya mengandung lima manfaat; menghilangkan duka, memperoleh penghidupan (rizki), ilmu, adab dan kemulyaan.

43. bait ke-61, 62, 63, 64, dan 65:

$$
\begin{aligned}
& \text { ع ما يبــــــاع و يوهب } \\
& \text { 61. فلقد نصحتلك إن قبلت نصيحت } \\
& \text { جاءت كنظم الدرّ بل هـ } \\
& \text { 62. خذه إليك قصيدة منظوم }
\end{aligned}
$$

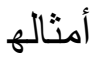

$$
\begin{aligned}
& \text { الأهيب } \\
& \text { غ لو عظ قصيدة و لاكم } \\
& \text { ه الشرف الرفي } \\
& \text { 65. أعنى عليّ }
\end{aligned}
$$




$$
\begin{aligned}
& \text { ـ فلقد نصدتلك إن قبلت نصديحت فالنصـح أغلى مـا يبـاع و يو هـب. خذها (أي النصسيحة) } \\
& \text { قصديدة منظومـ جـاءت كنظم الـدرّ بـل هـي أعجـب حكم و أداب و جـلّ مـو اء أمثالهـا }
\end{aligned}
$$

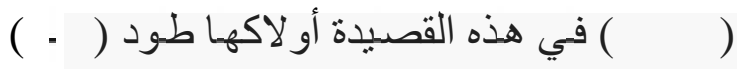

$$
\begin{aligned}
& \text { الأهيب (العالية المهيبة) (أي فصاحب هذه القصيدة هو الإمام علي ابن } \\
& \text { عمّ النبي صلعم وهو الذي نال الثرف الرفيع و النسب العالي). }
\end{aligned}
$$

- Aku sungguh telah menasihatimu (yang) jika kau terima, maka nasihat itu merupakan barang dagangan dan hadiah paling mahal. Jadikanlah nasihat itu qasidah berirama. Ia akan seperti untaian mutiara bahkan dia merupakan hikmahhikmah dan adab paling mengagumkan. Juga pesan-pesan tertulis yang paling agung bagi orang-orang yang berhati nurani. Condonglah pada pemberi nasihat yang telah memberimu gunung ilmu dan kemuliaan tinggi, yakni Ali putra paman Muhammad yang memperoleh kemulian nasab tinggi.

Si Aku menutup puisinya dengan menyatakan, mengingatkan kembali bahwa Si Kamu akan beruntung jika mengamalkan nasihat-nasihat yang ada di dalamnya. Nasihat adalah dagangan atau pemberian termahal karena nasihat dapat dijadikan pedoman seseorang untuk menjadi lebih baik. Pedoman menuju kebenaran dan keselamatan hidup di dunia dan akhirat.

Si Aku meminta Si Kamu menjadikan nasihat-nasihatnya menjadi satu kumpulan puisi agar mudah diucapkan dan diingat oleh banyak orang. Rangkaian baitnya nanti akan menjadi perhiasan yang lebih indah dan lebih berharga daripada untaian mutiara sekalipun. Di dalamnya terdapat hikmah-hikmah yang 
mengagumkan, budi pekerti luhur, pelajaran, dan perumpamaan terbaik bagi orang yang berakal sehat.

Kemudian Si Aku mengingatkan bahwa $\mathrm{Si}$ Kamu harus condong, menghormat dan yakin terhadap pemberi nasihat yang tak lain adalah dirinya, Imam Ali Ibn Abi Talib, putra paman Nabi yang mulia keturunannya, pemeluk Islam sejak kecil, dan hidup dalam asuhan Nabi Muhammad, orang yang disebut oleh Nabi sebagai pintu ilmu. Oleh karena itu apakah pantas jika ia menyangsikan kebenaran dan keagungan muatan isi puisinya.

Bait-bait terakhir ini menunjukkan kepandaian penyair dalam menentukan tokoh di dalam puisinya. Ia memakai kata Aku untuk menggantikan pembicara, tidak menyebut namanya karena ia tidak mau disebut sombong nantinya, atas keindahan dan kedalaman makna yang dikandung puisinya.

Penyair menunjuk Kamu untuk menyebut pendengar, orang yang dinasihati, yang juga dirinya sendiri. Hal ini menunjukkan bahwa ia berhati-hati dalam berucap, memilih pendengar. Tidak semua orang dapat menerima nasihat yang merupakan buah pikirannya. Ia juga ingin agar dirinya dapat mengamalkan dulu perkataannya sendiri sebelum menceramahi orang lain. Namun, bukan berarti kata-katanya ini tidak boleh diamalkan oleh orang lain. Ia tidak ingin termasuk golongan orang yang dibenci Allah karena hanya dapat berbicara tanpa mengamalkannya. Firman Allah menyebutkan sebagai berikut.

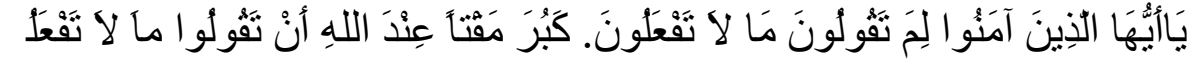
Hai orang-orang yang beriman, mengapa kamu mengatakan apa yang tidak kamu perbuat? Amat besar kebencian di sisi Allah bahwa kamu mengatakan apa-apa yang tiada kamu kerjakan(Q. S. As-Saaf: 1-2).
} 
44. Bait ke-66:

ق حصر ها لا يحسب

لا بحسب حصر ها.

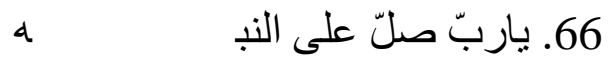

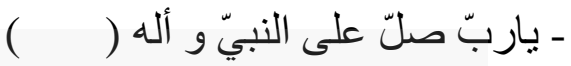

- Ya Tuhan, berilah rahmat atas Nabi dan keluarganya sebanyak makhluk yang bilangannya tak terhitung.

Sebagai penghujung bait-bait puisinya pengarang memanjatkan doa, sebagai tanda penghormatan dan rasa tawadu' kepada sosok yang memberikan jalan ilmu Allah sehingga sampai kepadanya, yaitu Nabi Muhammad Saw. Hal ini sebagai contoh dan anjuran bagi para murid agar senantiasa memuliakan guru, mendoakannya, dan menghormati keturunan serta keluarganya.

Penyair memilih kata-kata pilihan yang indah dan berbobot dalam memanjatkan shalawat kepada Nabi. Ia memanjatkan doa dengan memakai kata

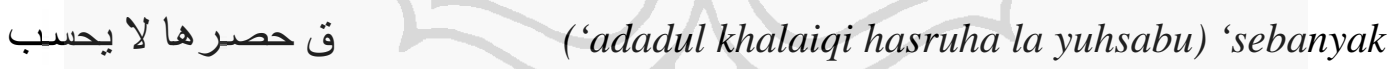
bilangan makhluk yang jumlahnya tak terbilang' untuk menyatakan betapa ingin ia mendoakan Nabi sebanyak mungkin. 


\section{BAB V}

\section{KESIMPULAN}

Berdasar penelitian dari segi semiotisnya, bait-bait puisi az-Zainabiyah Imam Ali ini mengandung banyak pilihan kata indah yang kaya makna, yang unsur-unsurnya saling mendukung dan memperkuat pesan yang ingin disampaikan. Dalam tiap bait juga selalu ada kata kunci yang menjadi inti permasalahan dari bait tersebut, sehingga memudahkan peneliti untuk menangkap makna yang ingin disampaikan pengarang.

Adapun garis besar makna puisi Imam Ali ini sebagai berikut.

- Bagian pertama sampai empat belas merupakan pendahuluan yang menyatakan bahwasanya kehidupan dunia tidak kekal, himbauan kepada manusia agar menyikapi kehidupan dari sudut pandang umur yang telah diberikan Tuhan dengan bijaksana, dan mengajak pembaca untuk merenung dan mengaca diri.

- Bagian ke lima belas sampai sembilan belas merupakan penjelasan bahwa manusia harus berhati-hati dalam menggunakan waktunya.

- Bagian ke dua puluh sampai dua puluh tiga merupakan anjuran untuk senantiasa bertakawa, taat kepada Allah dan rasul-Nya, qana'ah dan menjauhi sifat tamak.

- Bagian ke dua puluh empat merupakan anjuran untuk berhati-hati terhadap wanita karena wanita merupakan godaan terberat bagi orang yang beriman.

- Bagian ke dua puluh lima merupakan himbauan untuk menghadapi musuh secara terhormat. 
- Bagian ke dua puluh enam sampai tiga puluh satu merupakan peringatan untuk tidak berteman dengan pendendam, pendengki, pembohong, penjilat, juga anjuran untuk tidak membeda-bedakan teman dan keluarga karena tingkatan sosial yang berbeda.

- Bagian ke tiga puluh dua sampai tiga puluh enam merupakan anjuran untuk berhati-hati dalam berbicara, menjaga hati dari berbagai penyakit hati, serta menjaga rahasia.

- Bagian ke tiga puluh tujuh dan tiga puluh delapan merupakan anjuran untuk menyelaraskan ikhtiar dan doa, serta menyikapi musibah dengan sabar dan tawakkal.

- Bagian ke tiga puluh sembilan sampai empat puluh satu merupakan penjelasan tata cara bersikap pada masyarakat, tamu serta orang yang terdzalimi.

- Bagian ke empat puluh dua menerangkan bahwasannya setiap orang dianjurkan untuk berhijrah, merantau untuk menambah pengalaman dan memperluas pengetahuan..

- Bagian ke empat puluh tiga dan empat puluh empat merupakan penutup yang menyatakan bahwasanya puisi ini memang layak dijadikan pegangan hidup. 


\section{DAFTAR PUSTAKA}

Abdurrahman, Khalil. 2002. Hegemoni Quraisy.Yogyakarta: LKiS.

Aedi, Hasan. 2003. Skripsi: Puisi Asywaqun Ilal Huriyyati karya Abdurrahman Al-Khumaisi dalam Modern Arabic Poetry (Analisis Semiotik). Yogyakarta: tidak diterbitkan.

Baiquni, N.A., I.A. Syawaqi dan R.A. Azis. 1996. Indeks Alqur'an. Surabaya: ARKOLA.

Bakalla, M.H. 1984. Arabic Culture Trough Its Language and Literature. London: Kegan Paul International ltd.

Al-Bantani, Imam Nawawi. 2005. Nasaihul Ibad (nasihat-nasihat untuk para hamba). Bandung: Irsyad Baitus Salam.

Al-Baqa'i, Yusuf as-Syaikh Muhammad. 1988. Diwan Imam as-Syafi'i Abi Abdillah Muhammad Ibn Idris as-Syafi'i. Makkah: al-Maktabah atTijariyah Mustafa ahmad al-Baz.

Burhan, Nurgiyantoro. 1998. Teori Pengkajian Fiksi. Yogyakarta: Gadjah Mada University Press.

Chirzin, Muhammad. 2003. Glosari Al-Quran. Jogjakarta : Lazuardi.

Daif, Syauqi. 1961. Al Adabu al Arabi al Ma'asir. Kairo: Dar al-Ma'arif.

Farhat, Yusuf. 1995. Diwan Im. Ali Ibn Abi Talib. Beirut: Dar al-Kutub.

Hamid, Mas'an. 1995. Ilmu Arud dan Qawafi. Surabaya: Al Ikhlas University Press.

Al-Hasyimi, As-Sayyid Ahmad. 1965. Jawahirul Adab Fi Adabiyyat Wa Insya $i$ Lugatil Arabiyyah. Mesir: Dar al-Fikr.

Al-Husaini, H.M.H. Al-Hamid. 1997. Baitun Nubuwwah: Rumah Tangga Nabi Muhammad SAW. Bandung: Yayasan Al-Hamidy (Pustaka Hidayah).

Ibnu Manzur, Jamaluddin Muhammad Ibn Mukarrom al-Afriqy al-Mishry. tt. Lisan al-Arab. Beirut: Dar as-Sadir.

Ibnu Saraf, Abi Zakaria Yahya. 1994. Riyadu as-Salihin. Beirut: Dar al-Fikr.

Jabrohim. 2002. Metode Penelitian Sastra. Jogjakarta: Hanindita Graha Widya. 
Al-Jarim, Ali dan Mustafa Amin. 1961. al-Balagah al-Wadihah al-Bayan wal Ma'ani wa Badi'. Surabaya: Toko Kitab Al Hidayah.

Al-Karim, Abdul Aziz. tt. Diwan Amir al-Mukminin wa sayyid al-Bulagai wa alMutakallimin Al-Imam Ali Ibn Abi Talib Alaihi as- Salam.

Keraf, Gorys. 2001. Komposisi: Sebuah Pengantar Kemahiran Bahasa. Ende Flores: Nusa Indah.

Maryam, Siti dkk (editor). 2002. Sejarah Peradaban Islam dari Masa Klasik hingga Modern. Jogja: LESFI.

Nasif, Syekh Manshur Ali. 2003. At-Taju al-Jami'u li al-Usuli fi Ahadisi arRasuli jilid 5. Bandung: Sinar Baru Algesindo.

Pradopo, Djoko Rachmat. 2003. Prinsip Kritik Sastra. Yogyakarta: Gadjah Mada University Press.

2005. Pengkajian Puisi. Yogyakarta: Gadjah Mada University Press.

Al-Qur'an al-Karim.

Riffaterre, Michael. 1970. Semiotic of Poetry. Bloomington \& London: Indiana University Press.

Samad, Fitriah. 2002. Skripsi: Puisi Imam Ali Ibn Abi Talib kepada Hasan dan Husain dalam Diwan Imam Ali Ibn Abi Talib (Analisis Semiotik). Yogyakarta: tidak diterbitkan.

Sangidu. 2004. Penelitian Sastra: Pendekatan, teori, metode, teknik, dan kiat. Yogya: unit penerbitan Sastra Asia Barat fakultas Ilmu Budaya UGM.

As-Sayib, Ahmad. 1964. Usulu An Naqdi Al Arabi. Kairo: Maktabah An Nahdah Al Misriyyah.

Wellek, Rene dan Austin Warren. 1990. Teori Kesusastraan. DiIndonesiakan oleh Melani Budiman. Jakarta: Gramedia.

Yunus, Mahmud. 1973. Kamus Arab Indonesia. Jakarta: PT. Hidakarya Agung.

Az-Zarnuji, Syekh. tt. Tarjamah at-Ta'limu al-Muta'allim Tariqu at-Ta'allum. Surabaya: Al-Hidayah. 
اللغة العربيّة أحد لغة لها أغنى فنّ الأدب في العالم. بتتبع الأثر قد جاوز

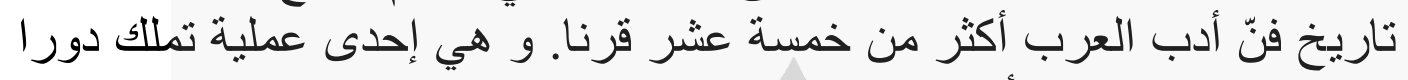

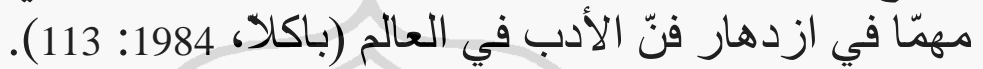

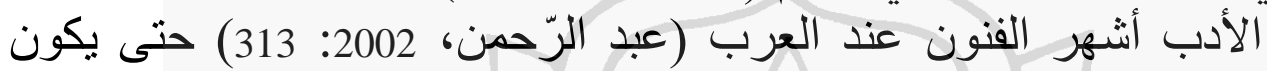

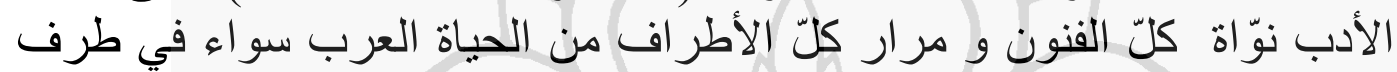

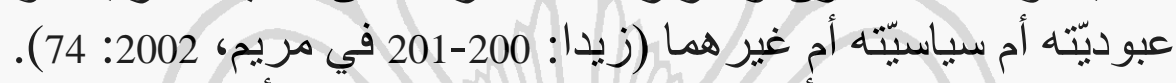

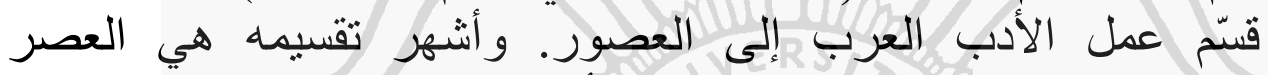

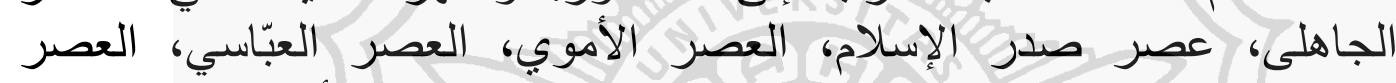
المملوك، و العصر الحديث. و لكل عصر خصائص مخالف الأخر (باكلا، 1984:

في عصر صدر الإسلام، ذهب ناقدو الأدب أنّ هناك قو لان عن ازدهار .(114

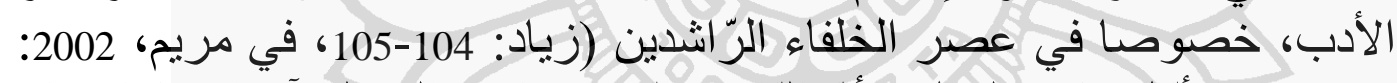

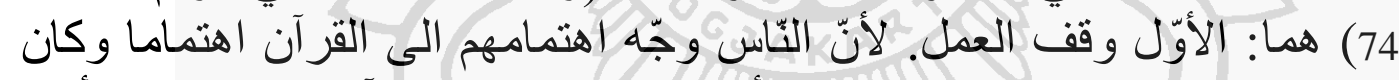

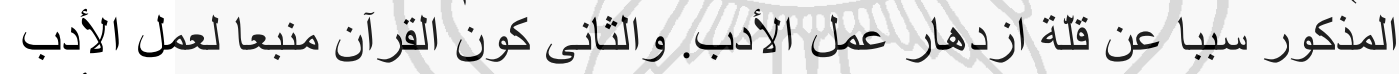

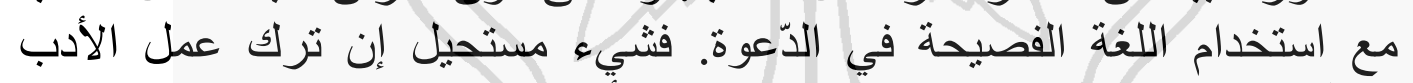

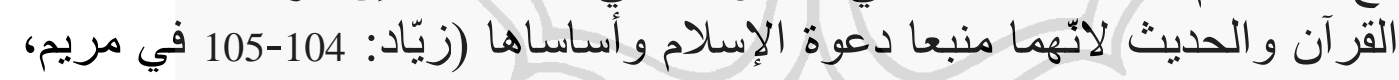
2002: 74)

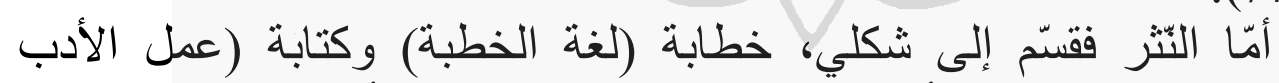

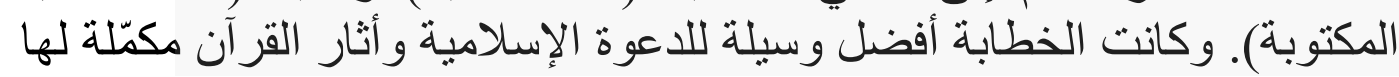

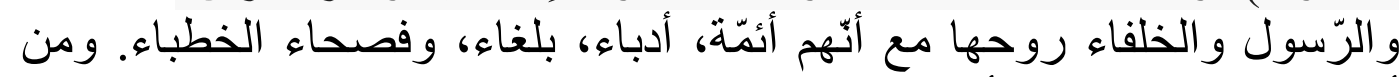

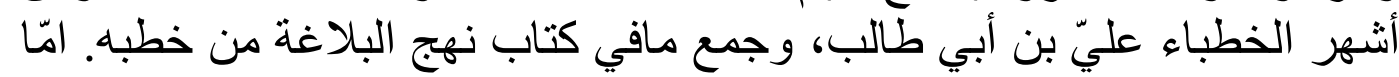

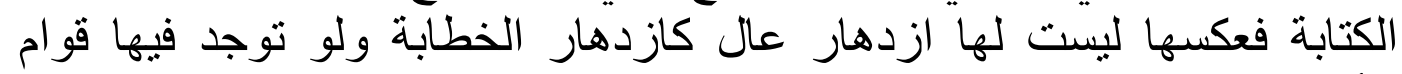

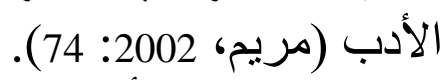

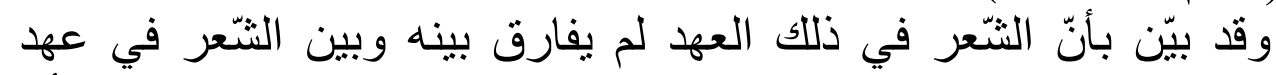

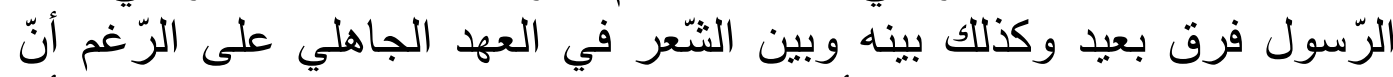

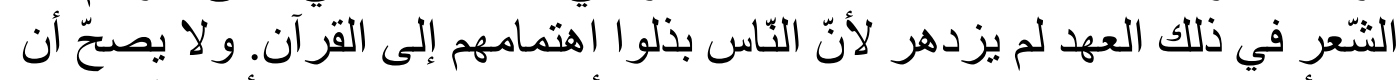

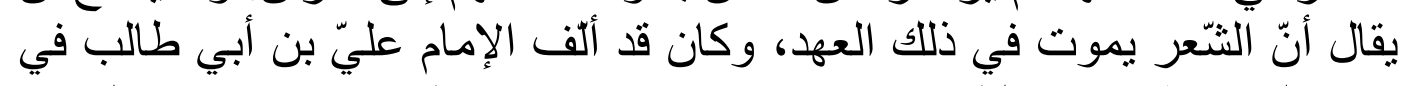

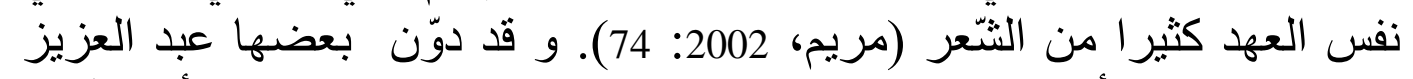

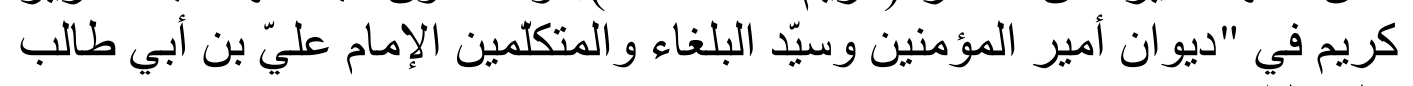
عليه السّّلام". 
يوجد فيها كثير من الوصايا لمن قرأها وإحدى موضوعها "الزّينبية"

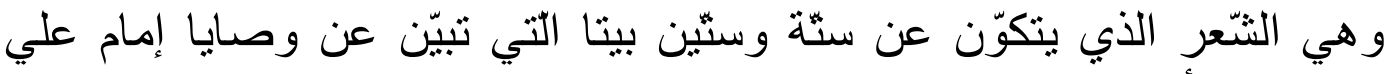

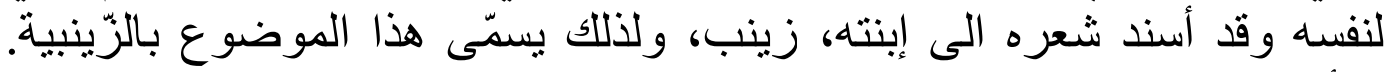

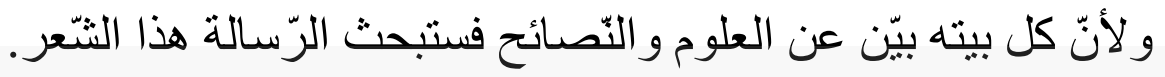

بناء على أساس السّالف في خلفية المسألة فالمسألة التي ستبحث في هذه التئ

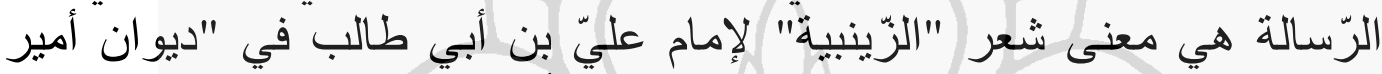

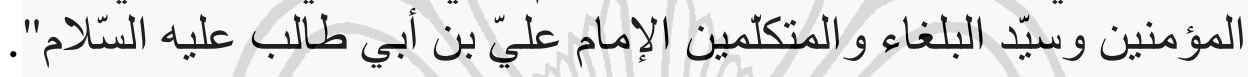

لهذه الرّّسالة هدفان هدف عمليّ وهدف نظريّ أمّا الهدف العمليّ فهو 1.3 هداف البحث

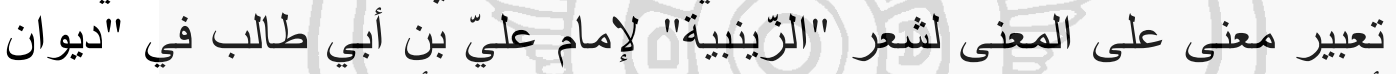

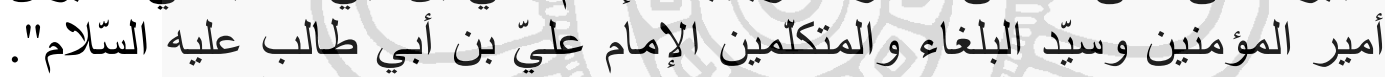

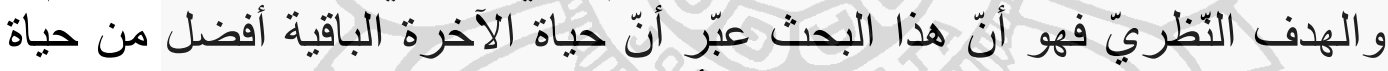

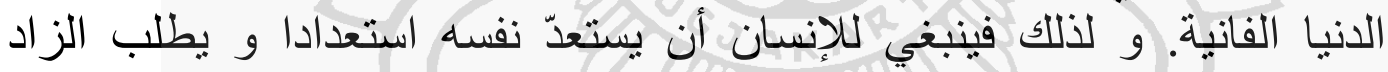
لاستعداد حياة الآخرة.

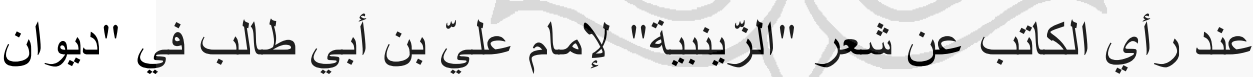

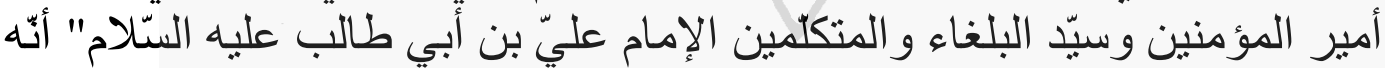

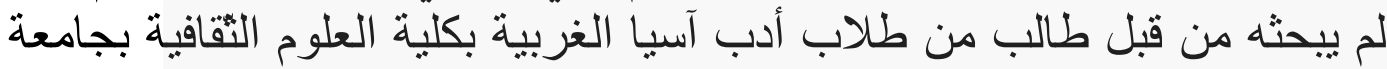

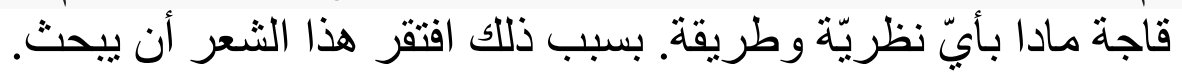

\section{5}

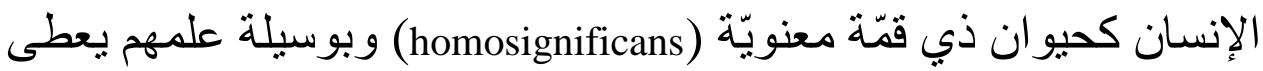

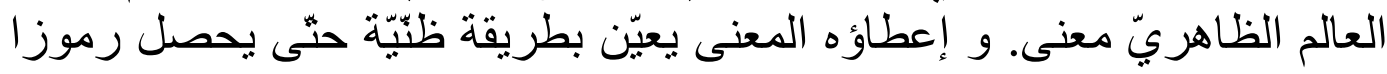

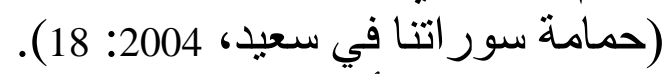

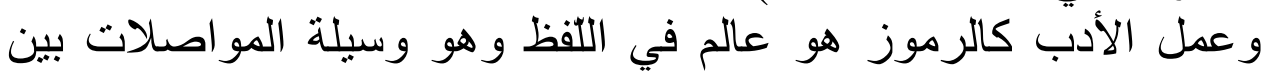

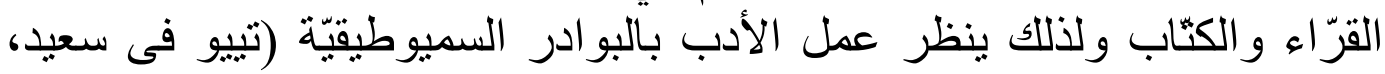




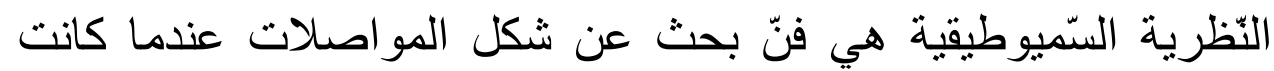
المواصلات جرت بالرموز وتبعا على أساس نظام الرّموز أو الإشئارة (سيغير في سعيد، 2004: 18).

وكانت اللغة مع كونها وسيلة إلى عمل الأدب نظاما سميوطيقيّا أو نظاما

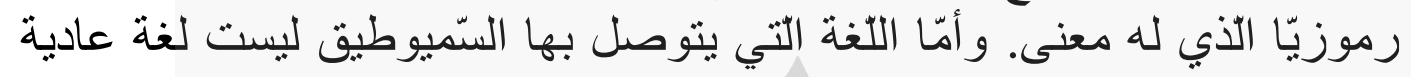

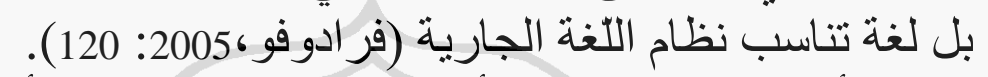

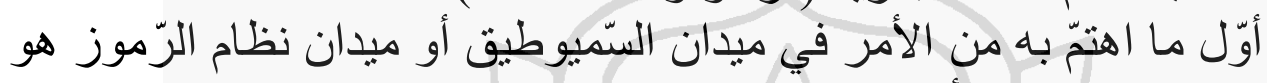

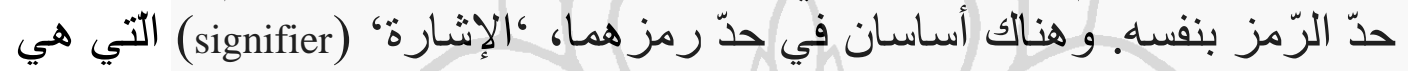

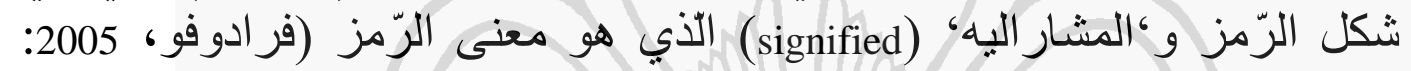
.) (121

أمّا اللغة مع أثّها نظام الرّموز فوسيلة عمل الأدب فهي نظام الرّموز

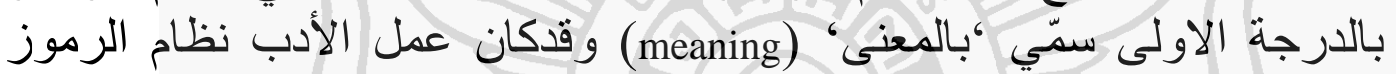

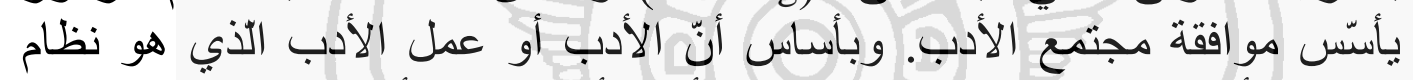

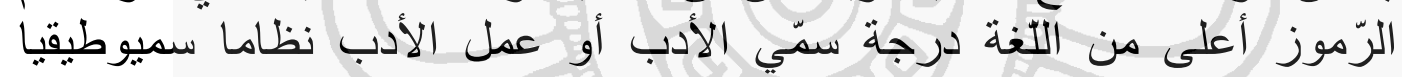
بالدرجة التَانية.

و للغة مو افقة معيّنة وفي ميدان الأدب سيناسق هذه الموافقة بمو افقته.

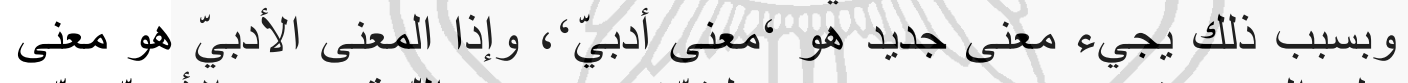

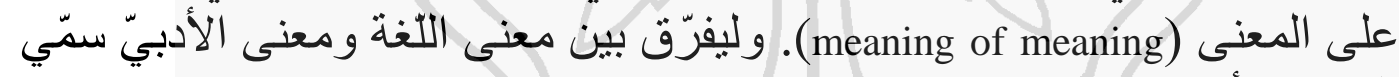
المعنى الأدبيّ ب(singnificance) (فر ادوفو ، 2005: 120).

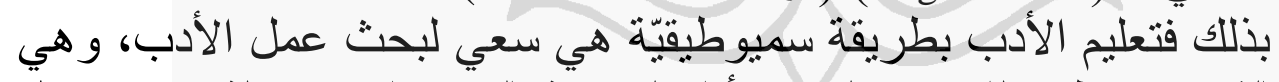

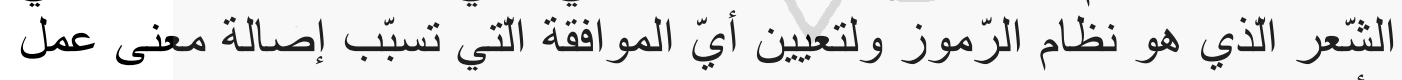

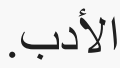

\section{6 طريقة البحث}

بناء على ما ذكر في النّريّة الأساسيّة فالطريقة المستخدمة هي تحليل

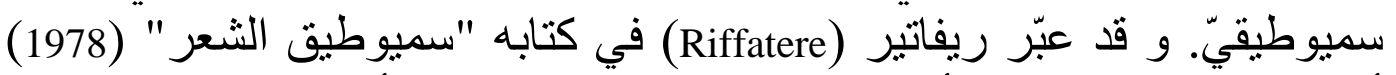

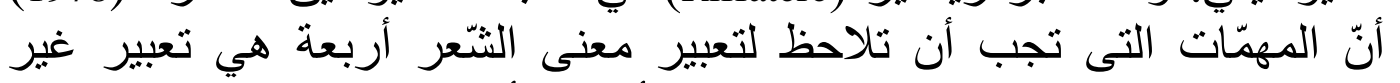

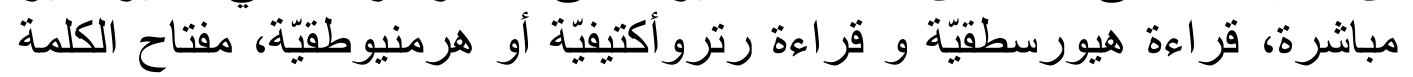

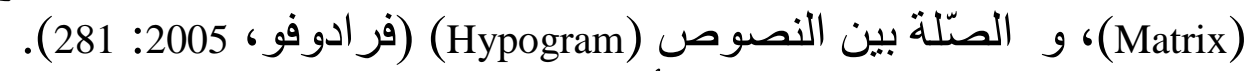

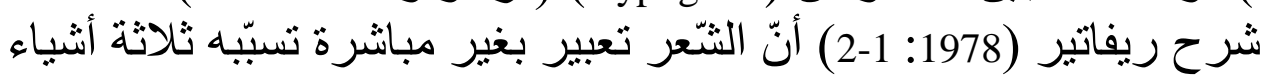

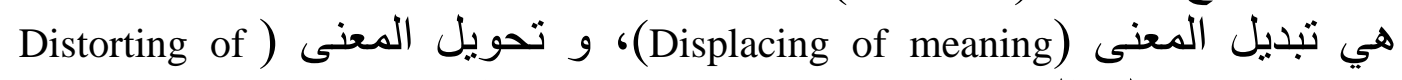
(meaning)، و خلق المعنى (Creating of meaning) (فر ادوفو ، 2005: 282). 


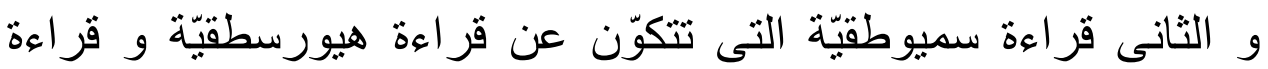

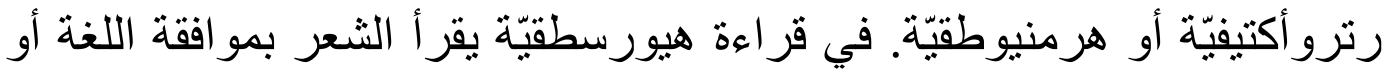

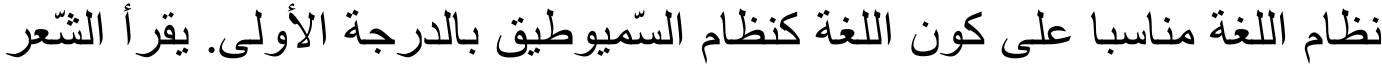

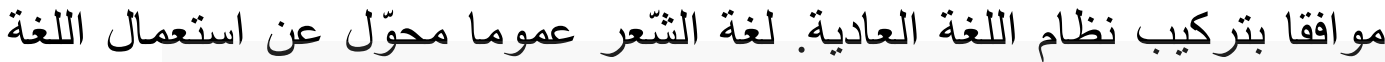

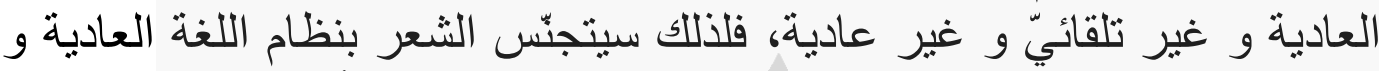

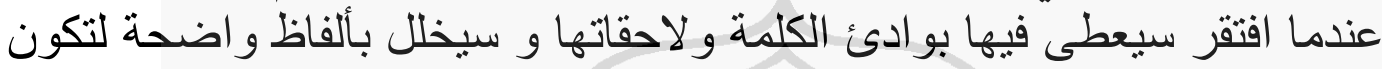

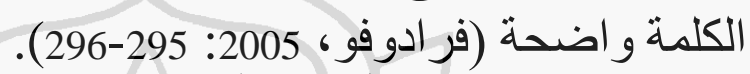

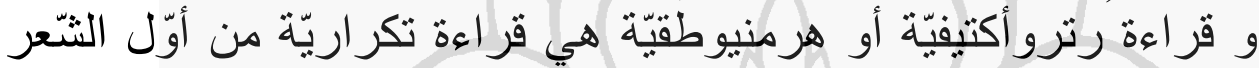

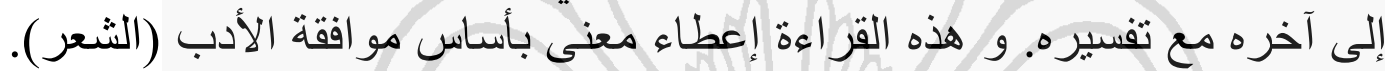

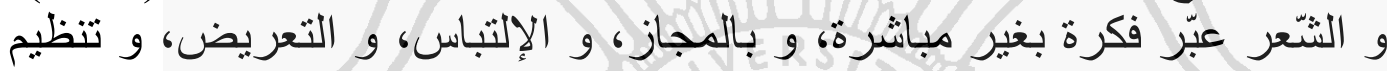

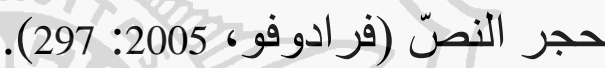

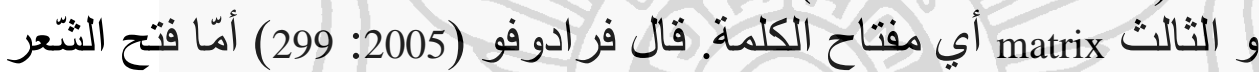
لبسهل الفهم به في تحقيقه فلا بدّ أن بطلب مفتاح الكلمة هي كلمة فاتحة الثنسير

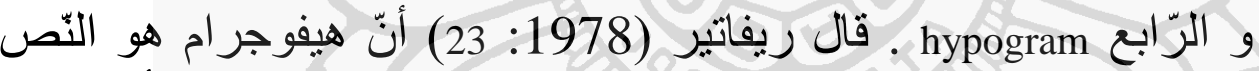

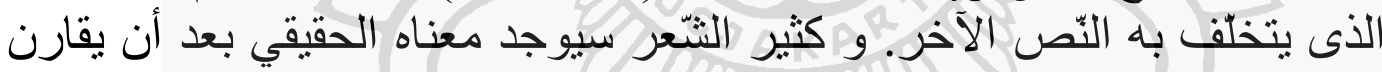

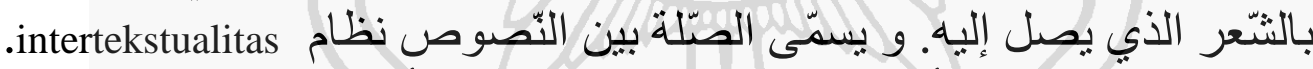

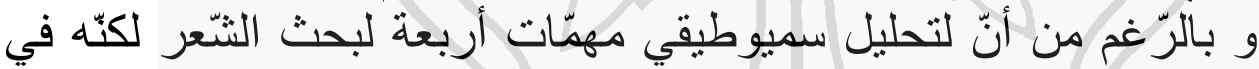

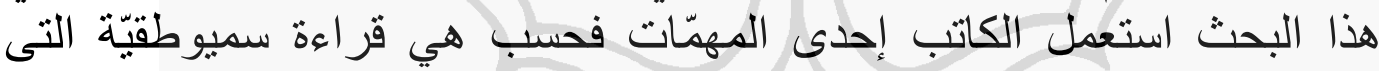

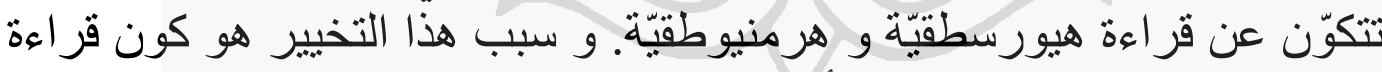

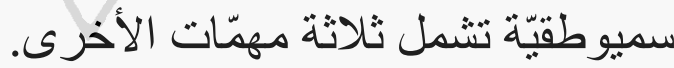

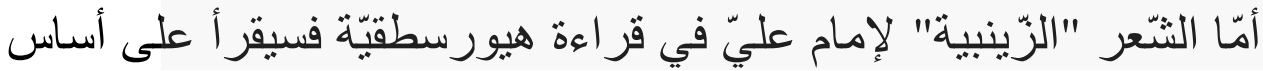

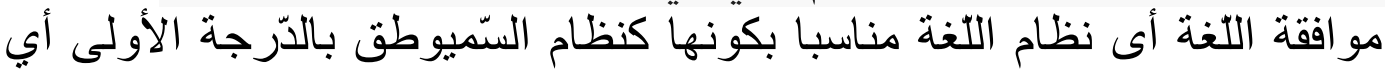

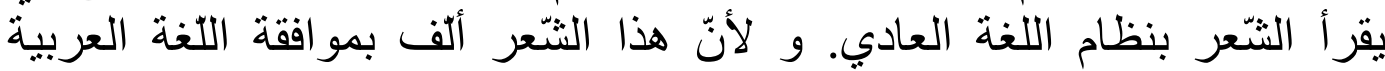

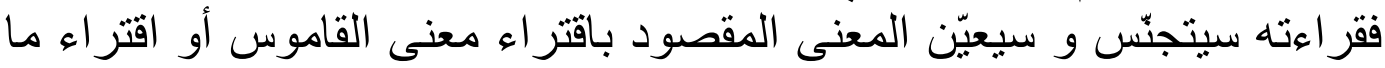

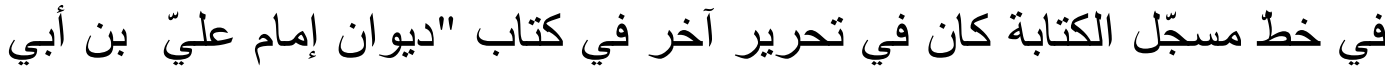

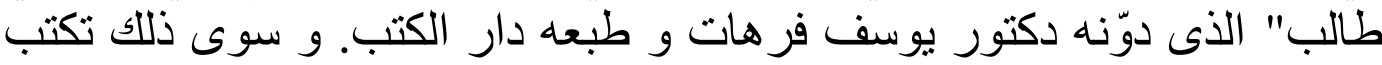

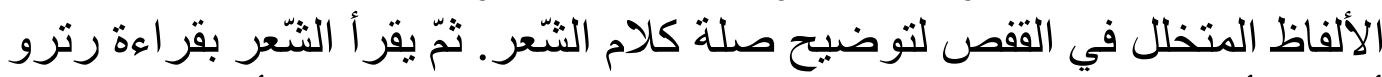

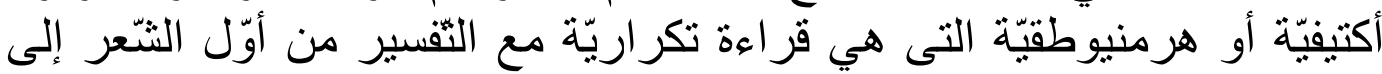

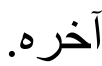

1.7 ترتيب البحث تئر

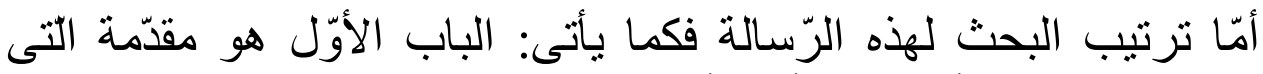

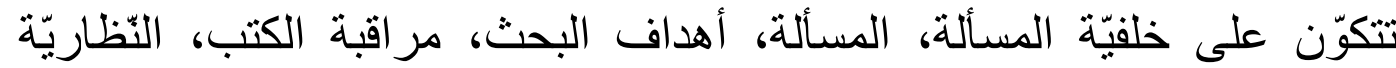




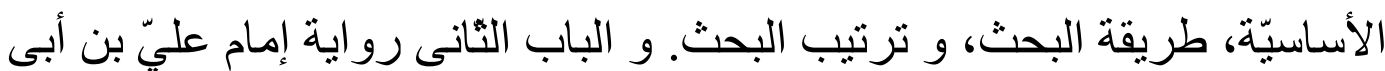

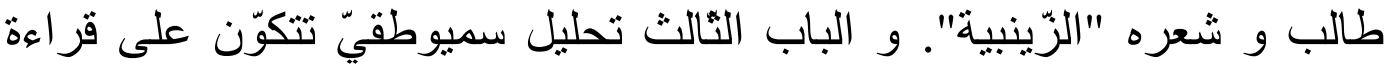

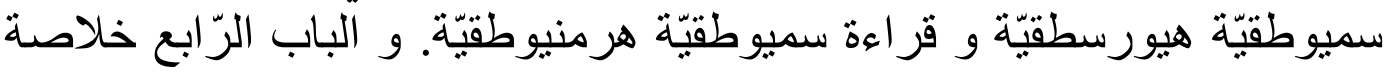
البحث.

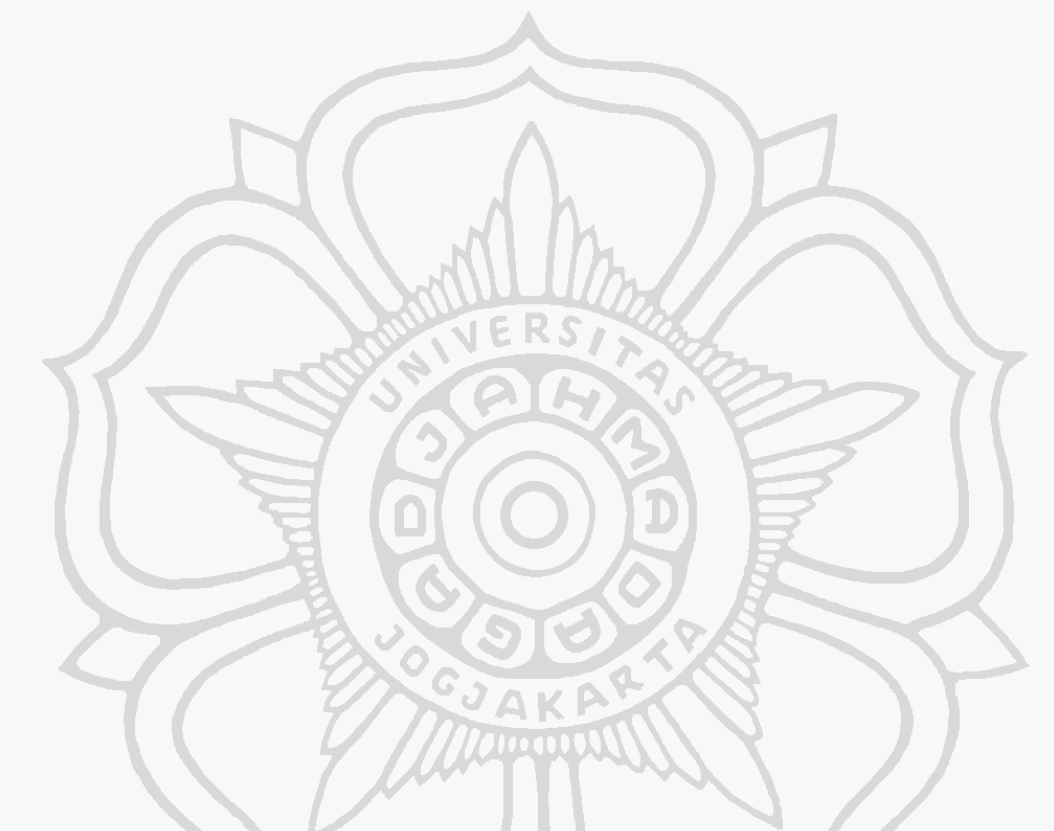

رواية إمام عليّ بن أبي طالب و شعره "الزّينبية"

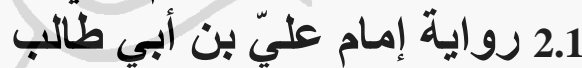

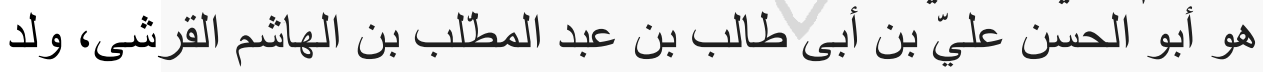

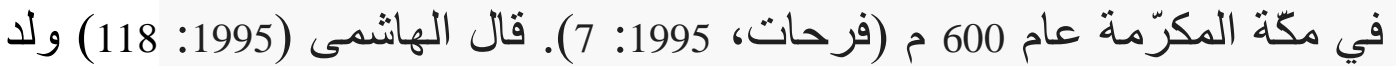

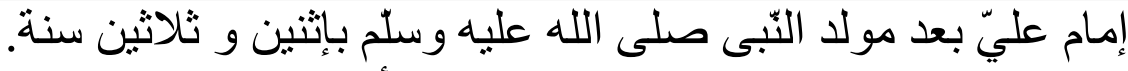

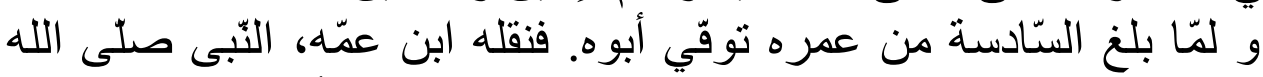

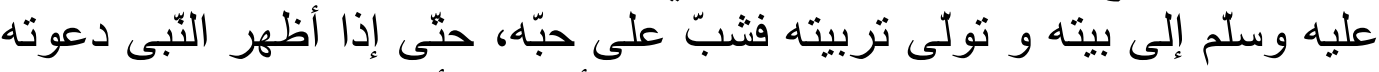

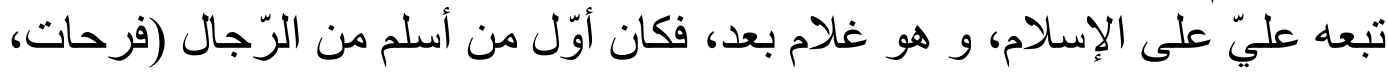
1995:

و كان كبير القلب، شديد الإخلاص، قويّ الإيمان، يذوب غيرة إنهاء في سبيل

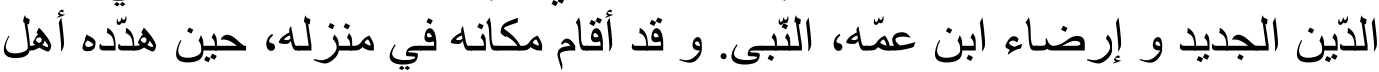

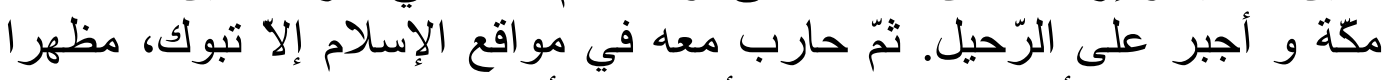

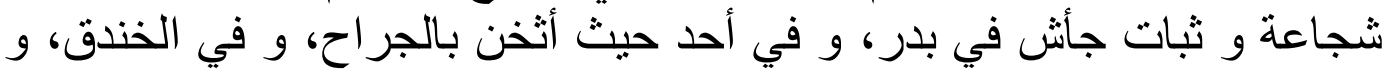

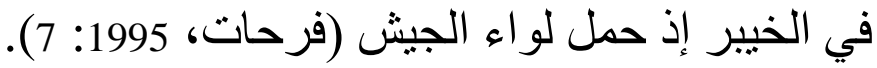

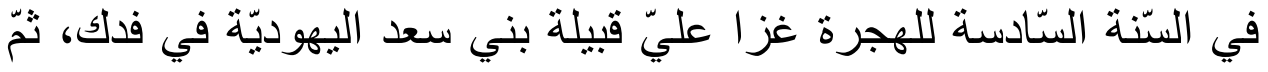

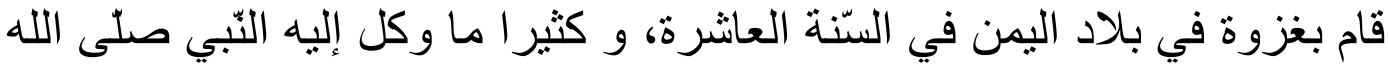


عليه وسلم أمور ا مهمّة، فكان يقوم بجميع الأعمال برغبة و حماسة نادرتين،

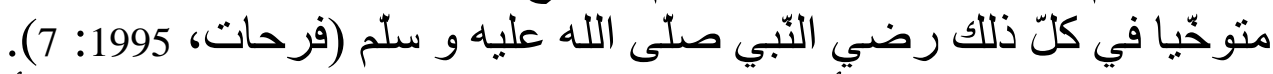

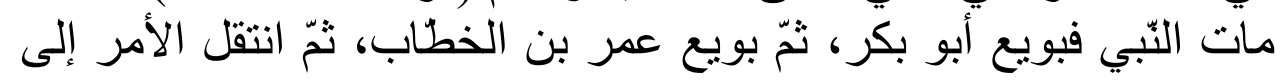

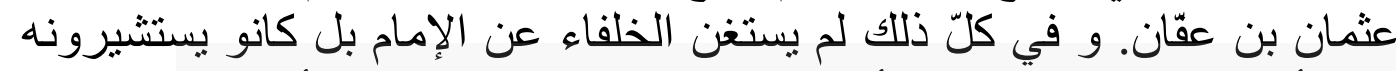

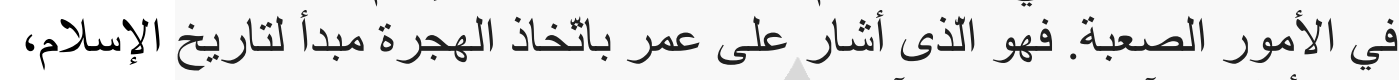

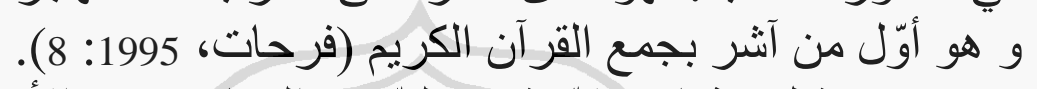

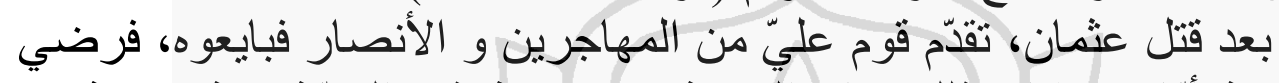

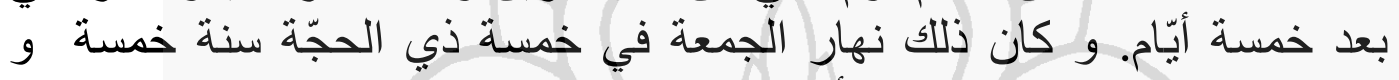

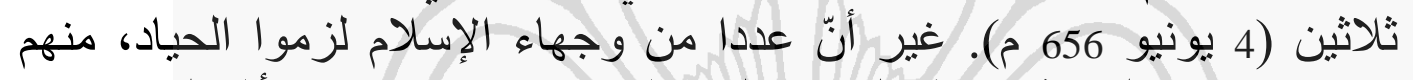

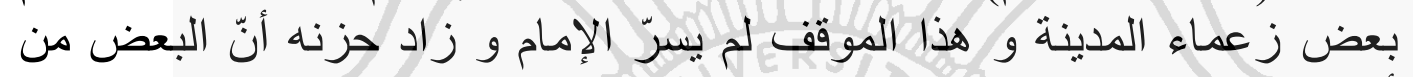

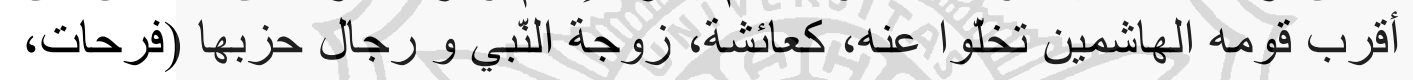

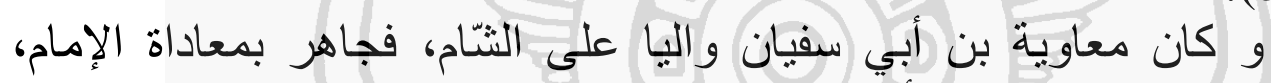

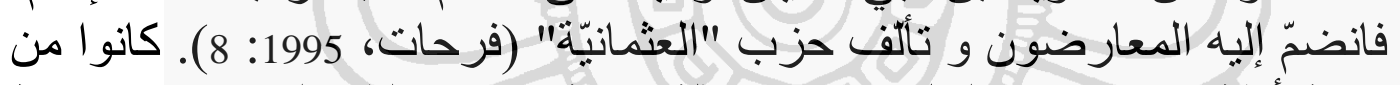
شيعة أميّة غضبا منهم لقتل عثمان و قلّة عنابية الإمام علي بالبحث عن عن معرفة

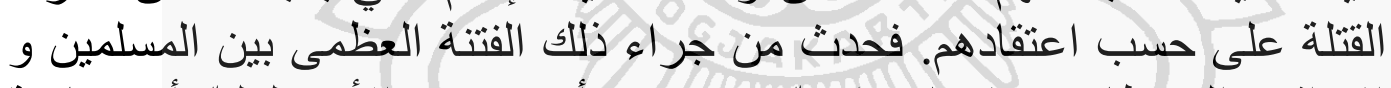

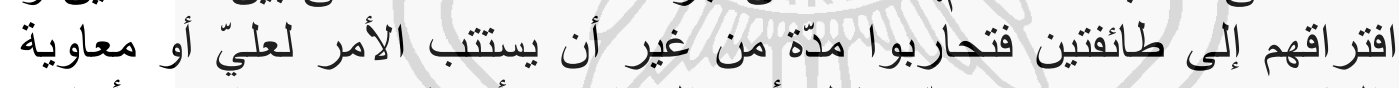

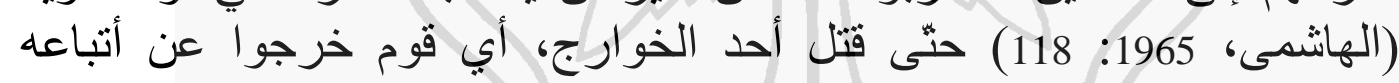

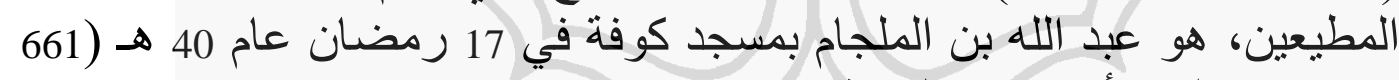

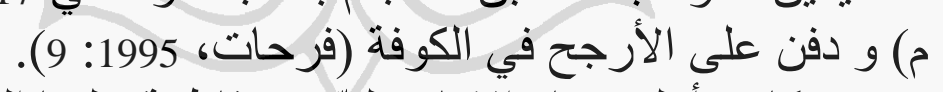

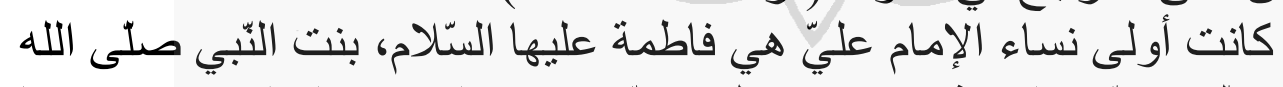

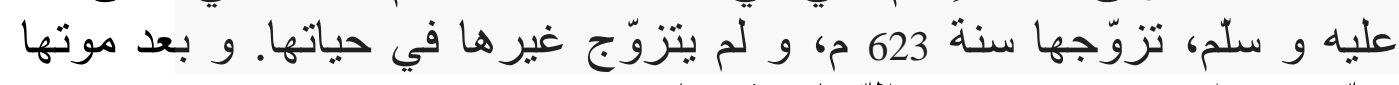

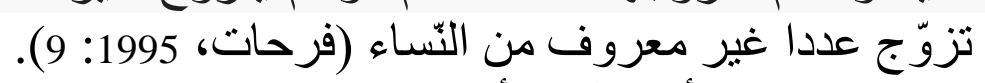

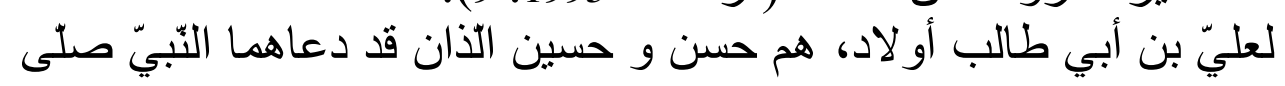

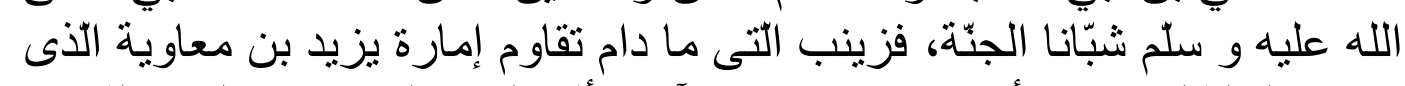

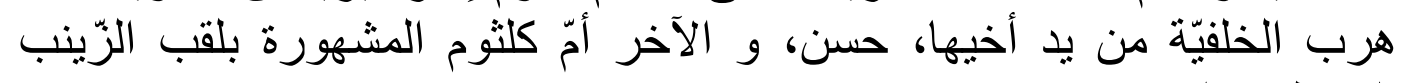
الوسطى (الحسينى، 1997).

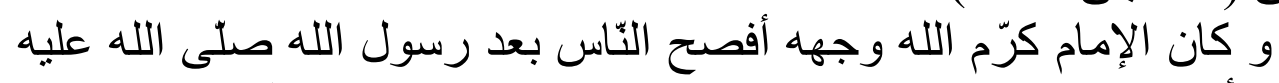

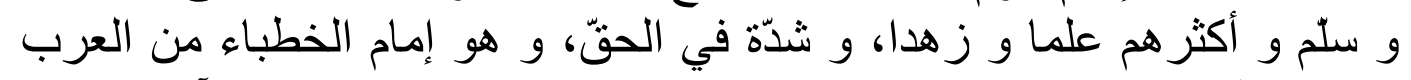

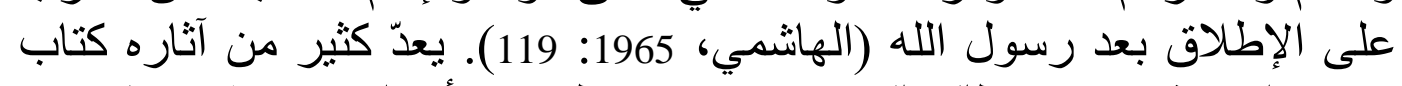

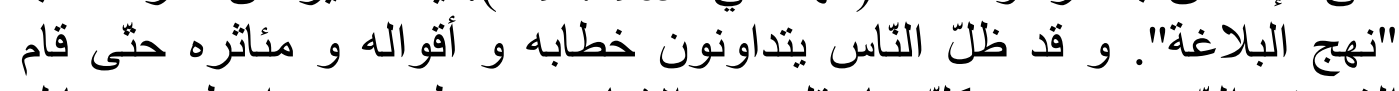

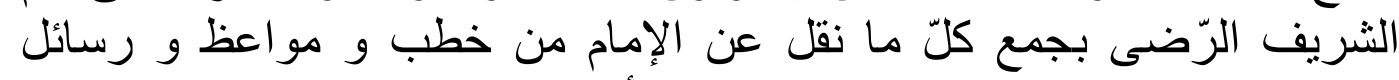

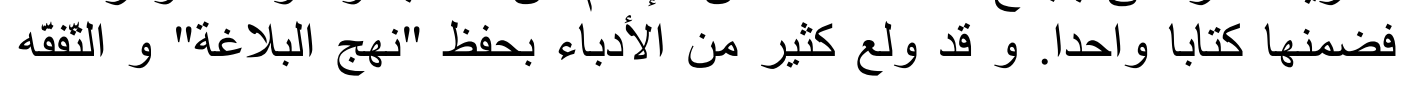

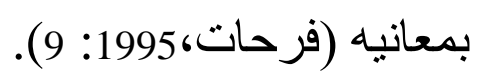




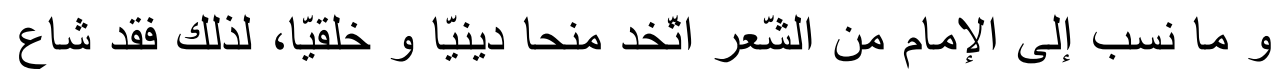

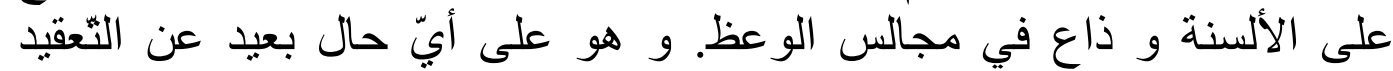

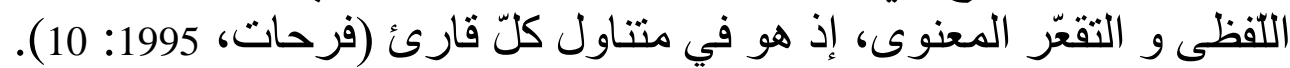

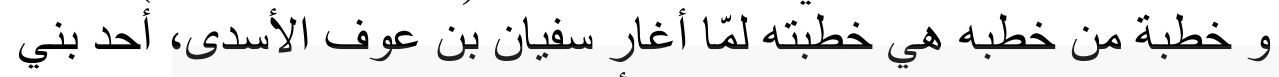

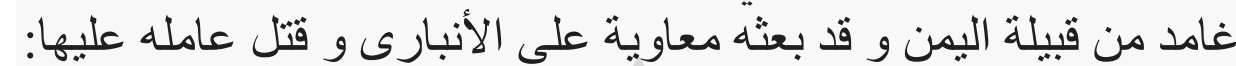

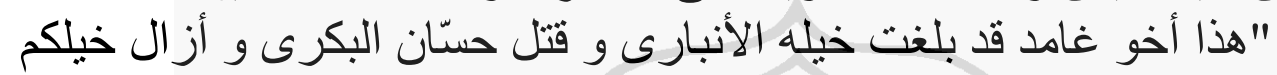
عن مسالحهاو قتل منكم رجالا صالحين. و قد بلغني أنّ الرّجل منهم كان الان يدخل على المر أة المسلمة و الأخرى

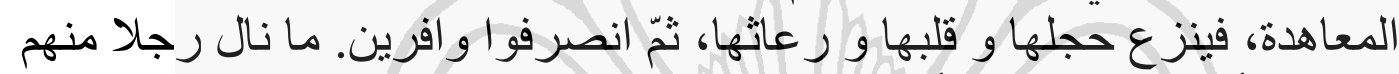

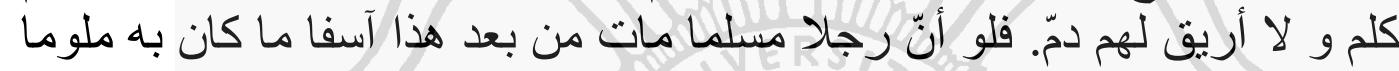
بل كان عندي جديرا.

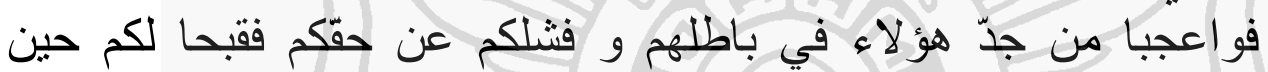

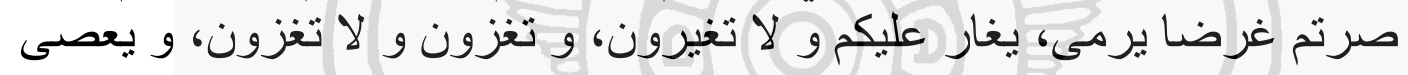

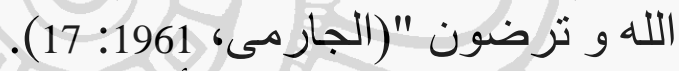

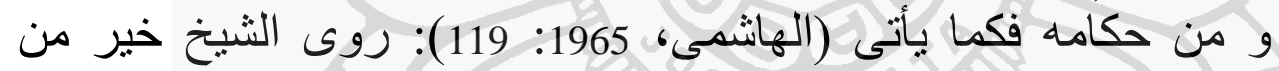

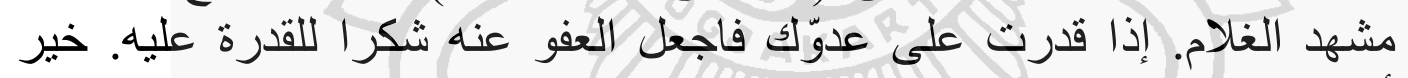

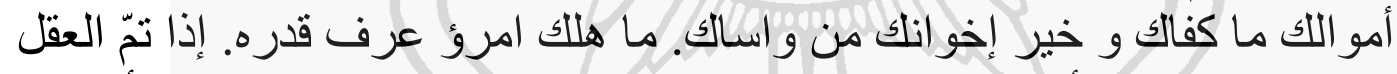

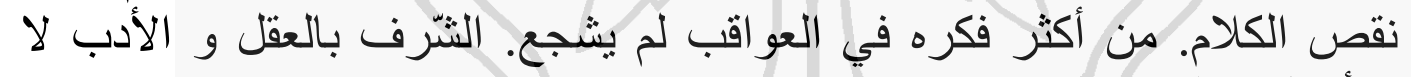
بالأصل و النسب. 


\section{الزينبيّة}

\section{"الزينبية}

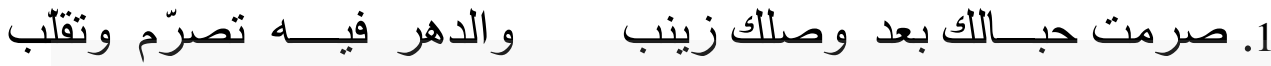

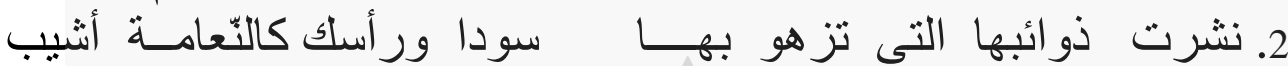

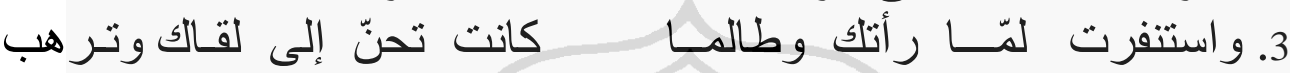

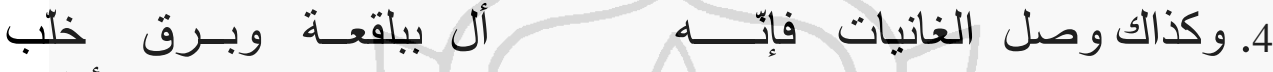

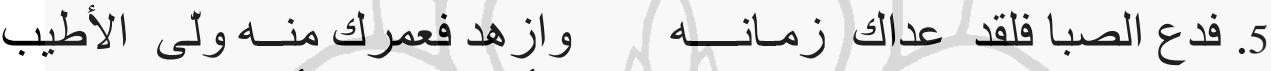

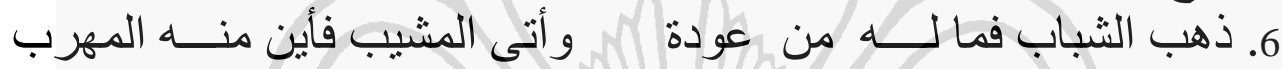

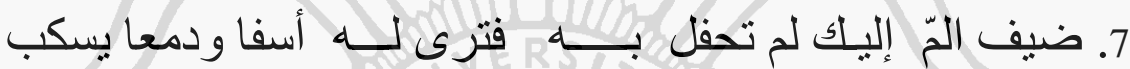

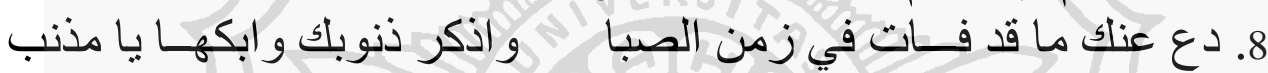

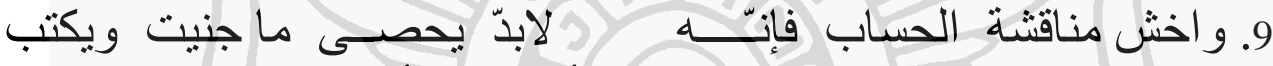

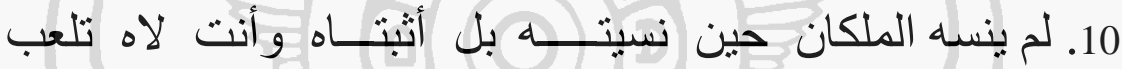

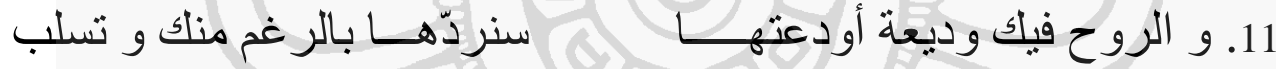

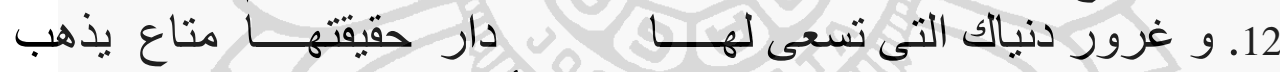

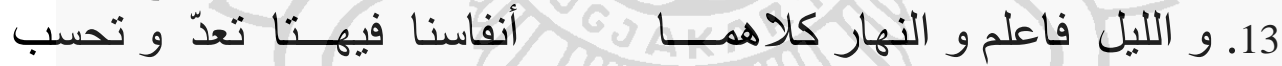

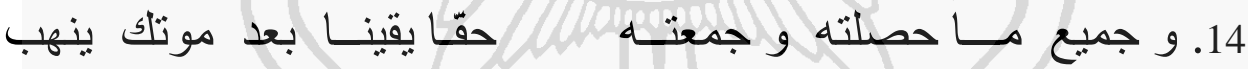

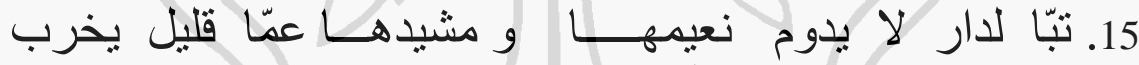

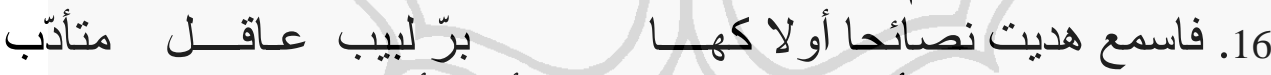

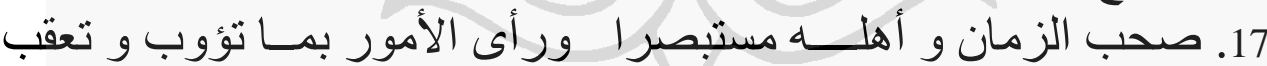

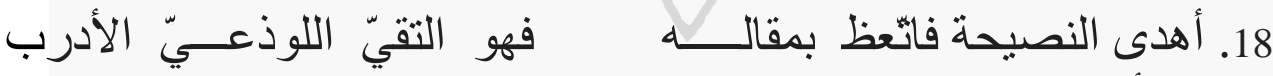

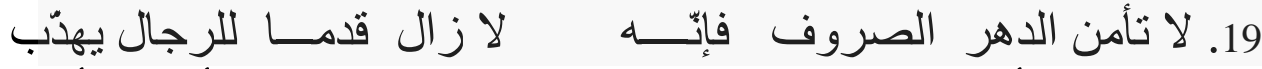

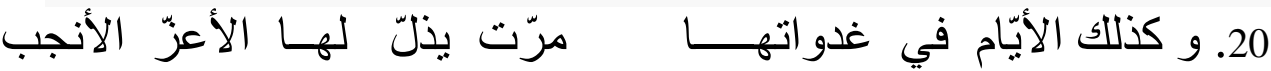

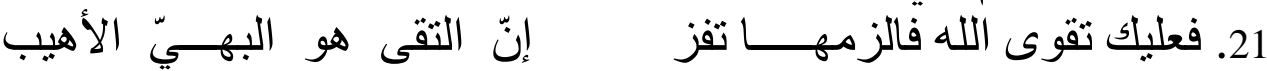

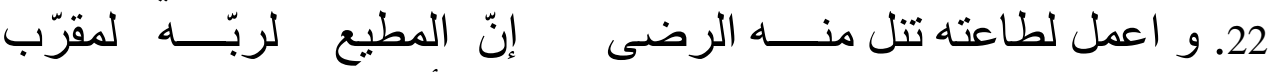

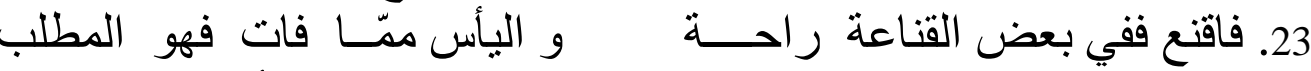

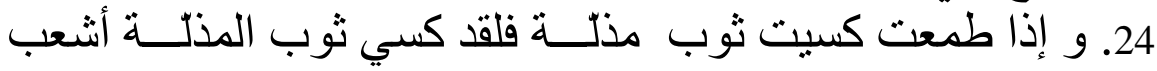

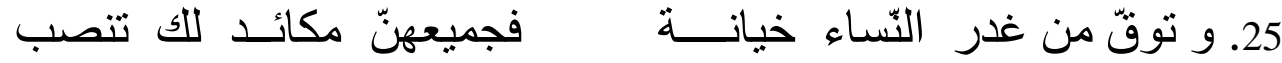

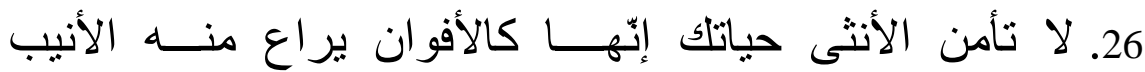

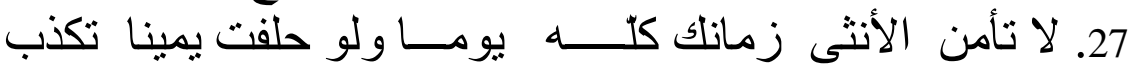

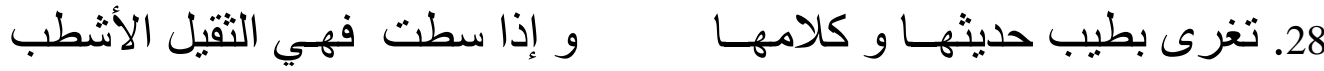

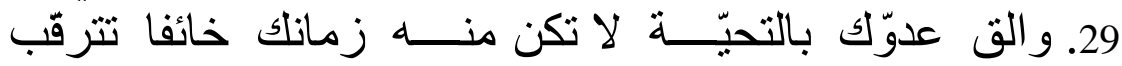

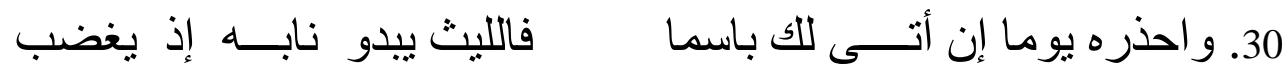

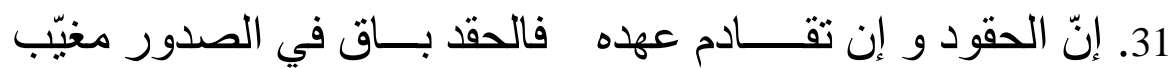




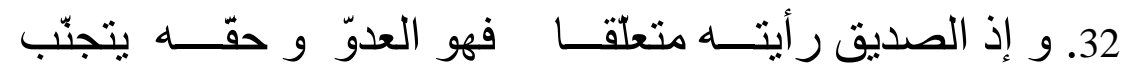

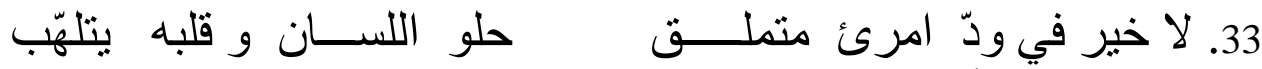

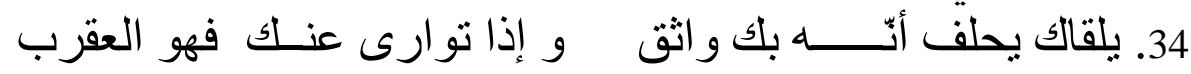

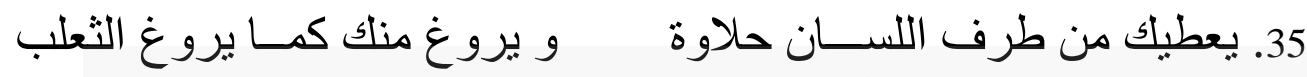

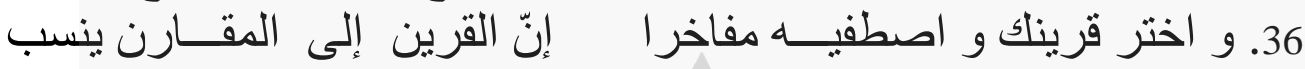

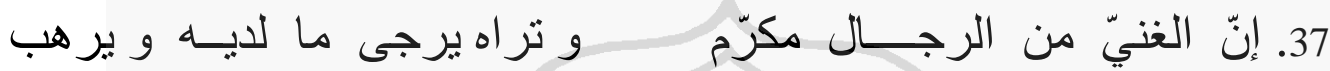

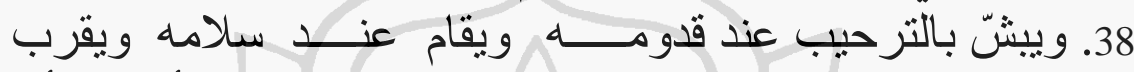

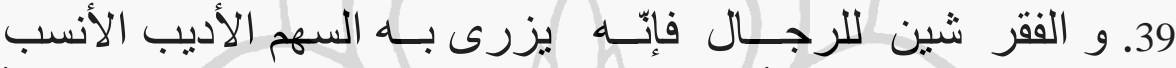

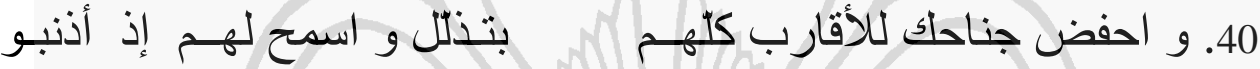

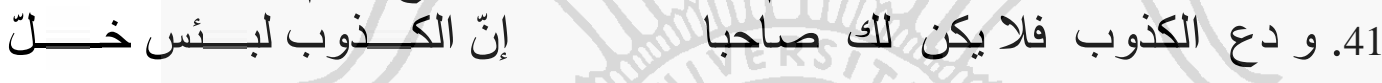
42. وذر الحسود ولو صفـا للك مزّة د أبعده عن رؤيسالك لا يستحلب

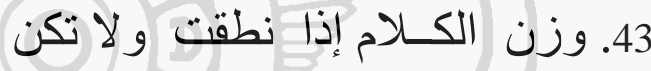
ثرثارة في كلّ نــاد تخطب

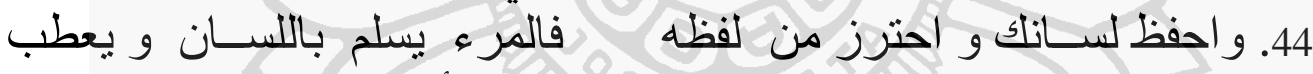

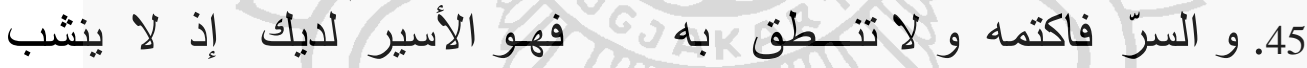

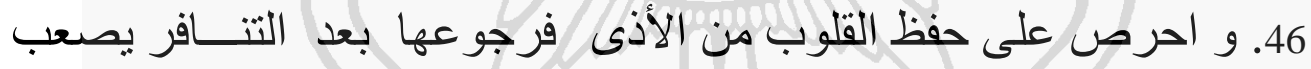

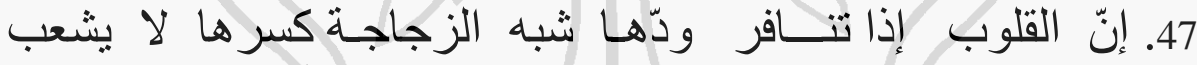

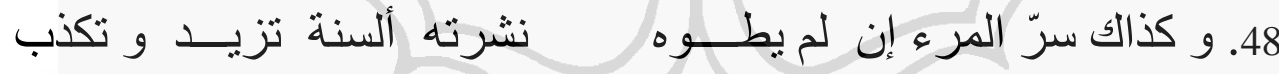

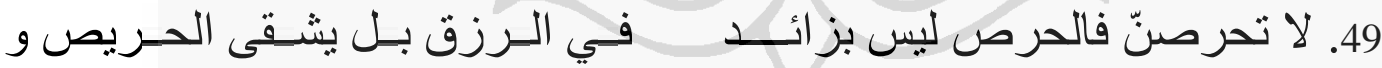

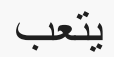

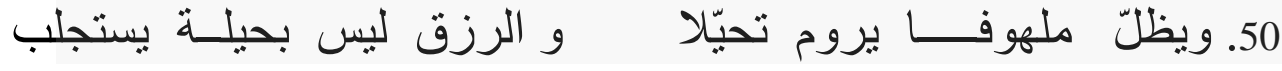

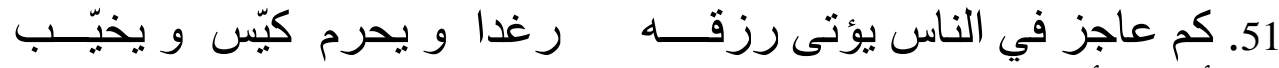

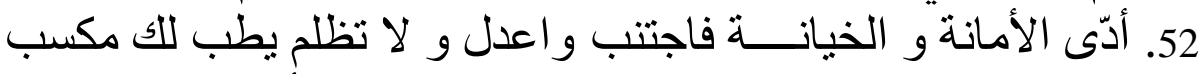

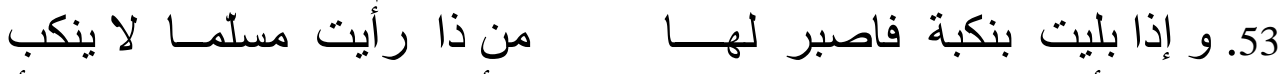

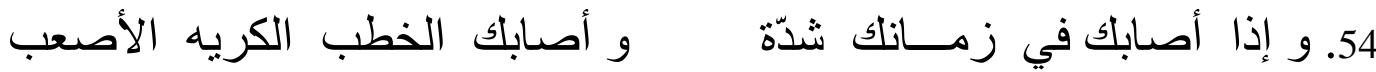

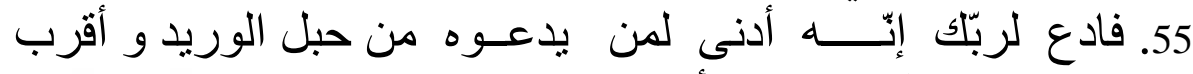

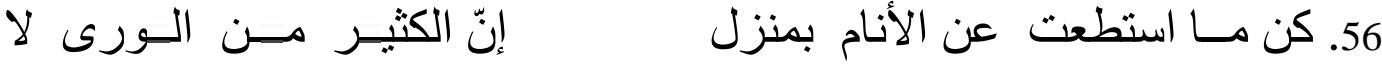

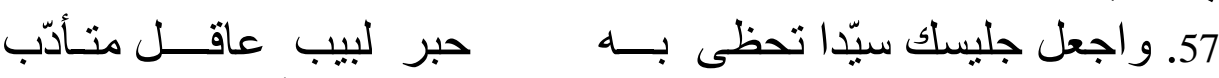

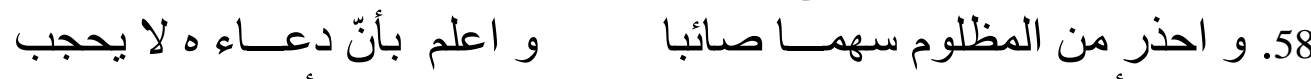

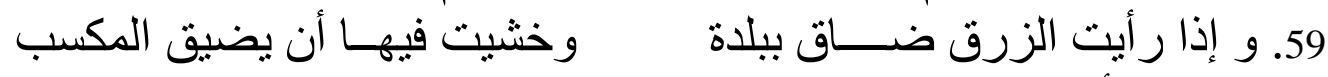

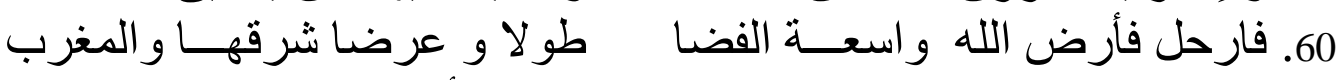

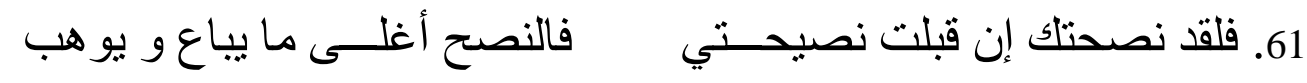




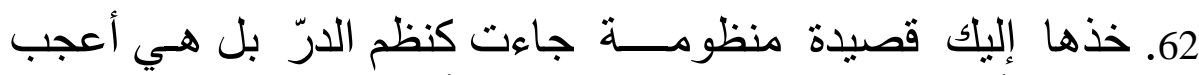

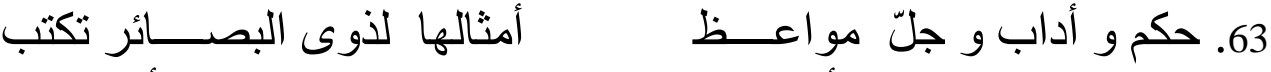

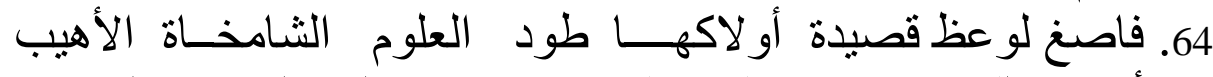

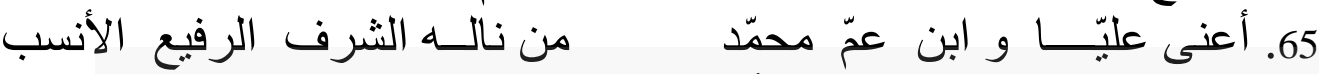

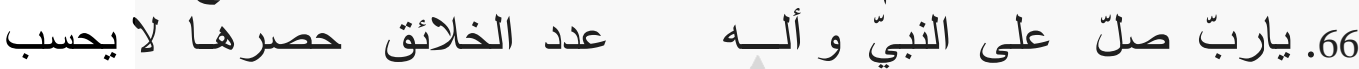

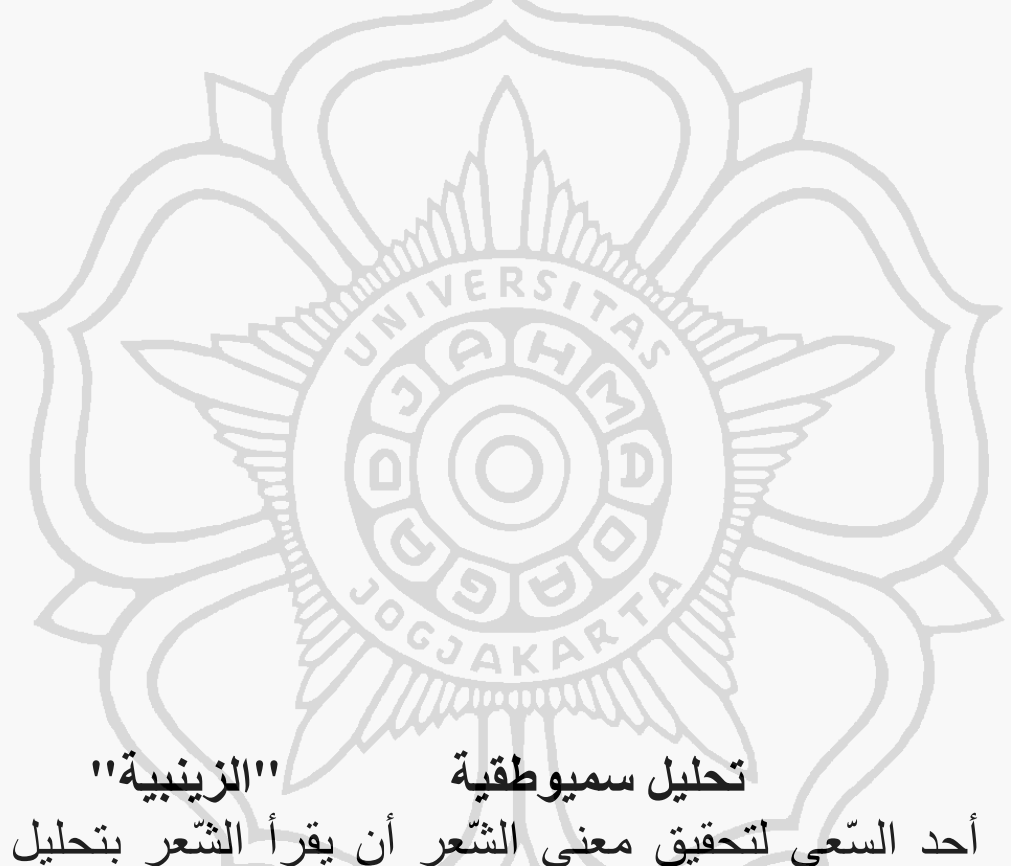

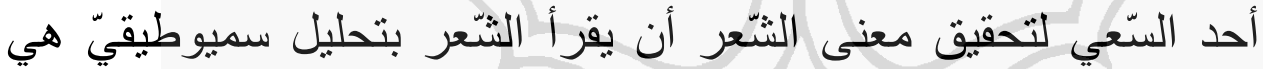

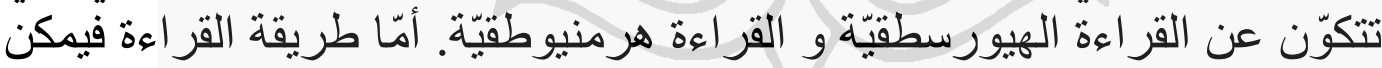

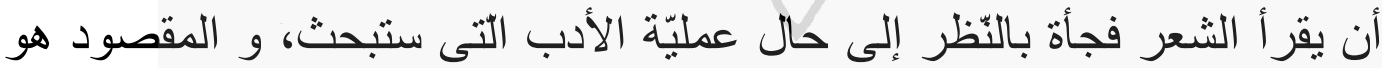

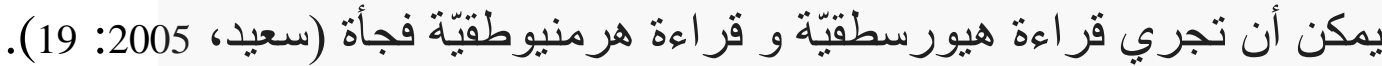

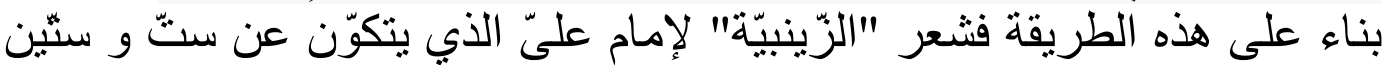

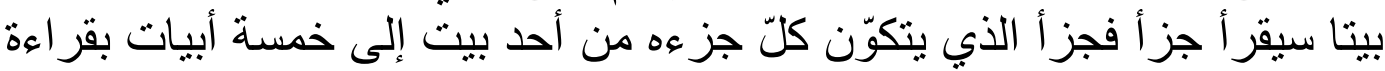

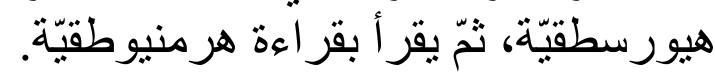

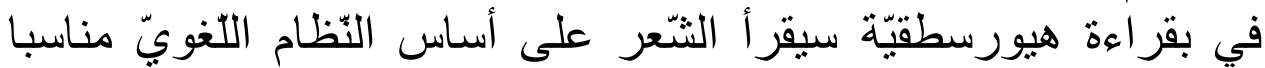

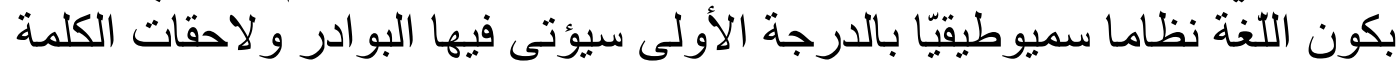

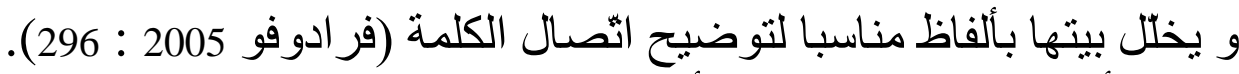

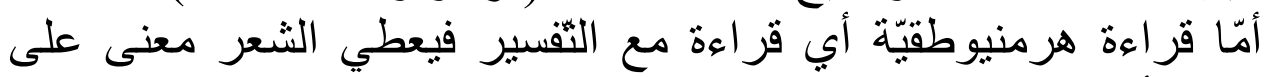

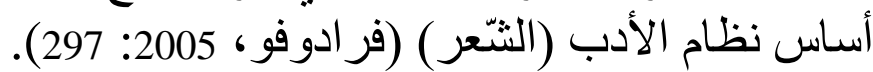

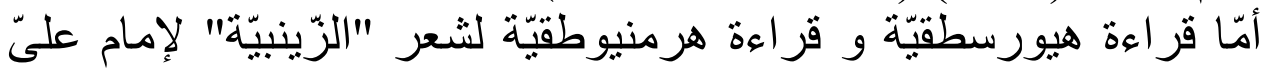

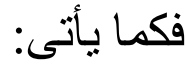




$$
\begin{aligned}
& \text { الزّينبيّة }
\end{aligned}
$$

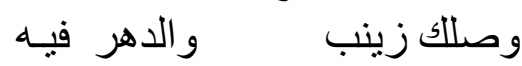

ـ صرمت (قطعت) زينب حبالك (علاقتها بك) بعد وصلك ومبه (حبّك) و الدهر فيه

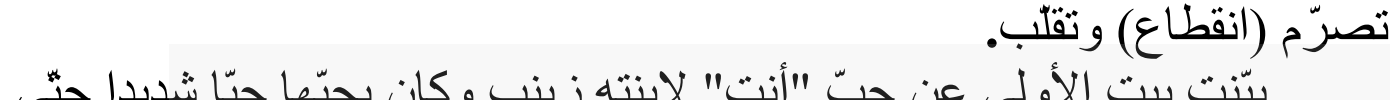

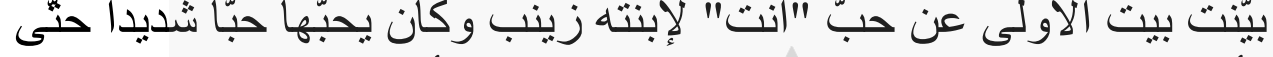

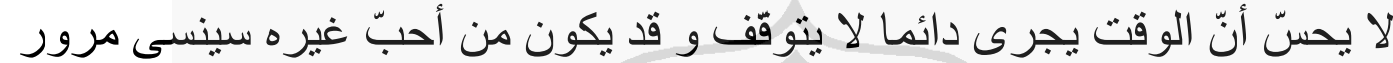

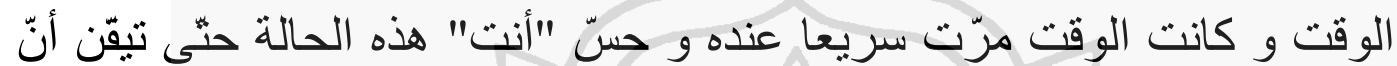

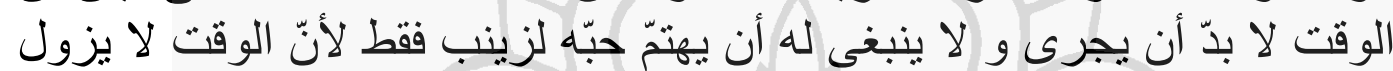

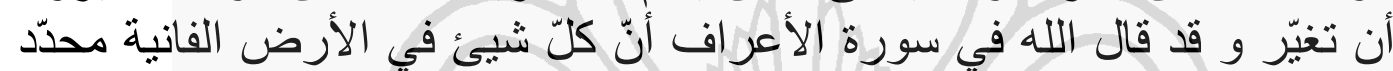

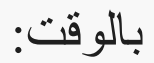

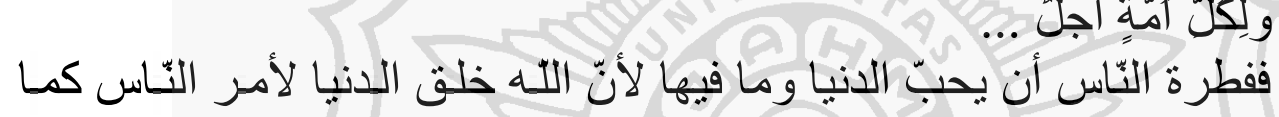

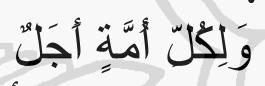

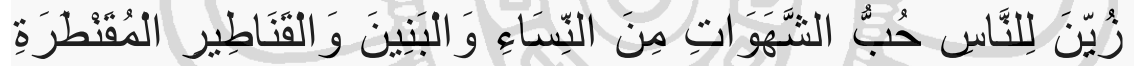
قال تعالى: - مالى

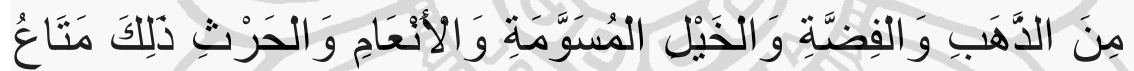

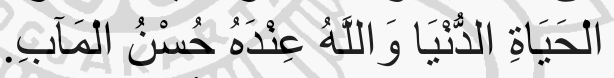

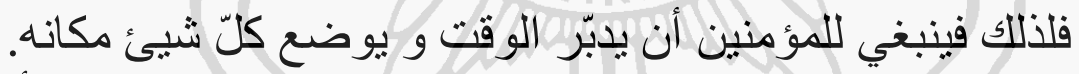

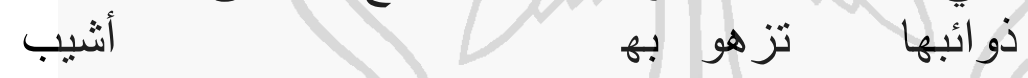

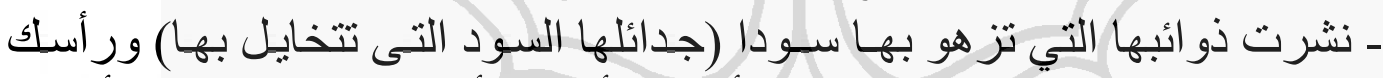

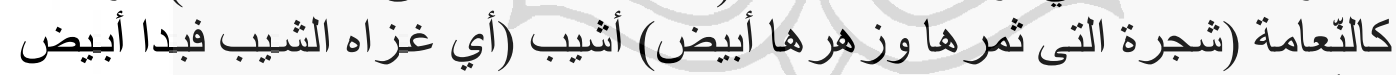

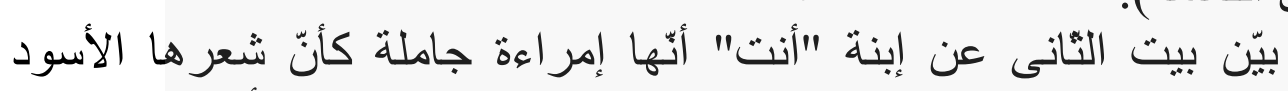

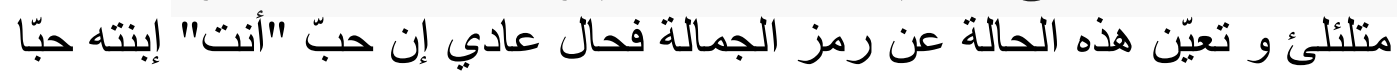
كبير إن و عبّر النّاظم في هذ البيت عن مقارنة بين شعر إبنته الأسود و شعره

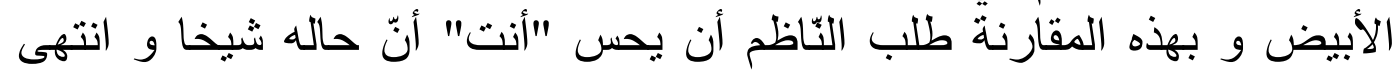

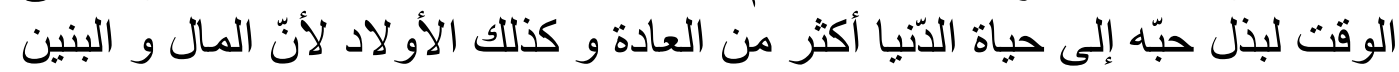

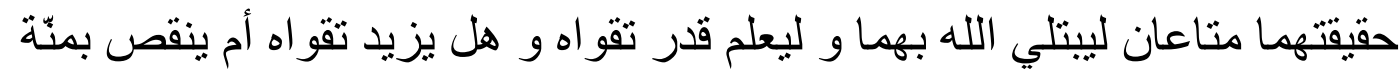

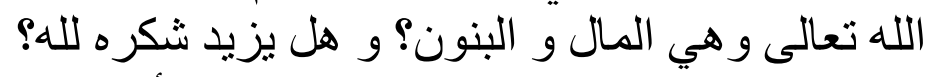

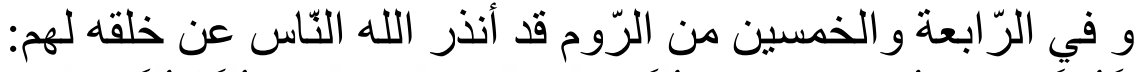

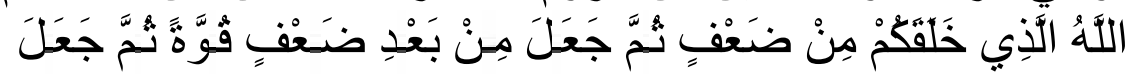

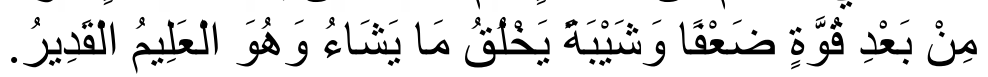

$$
\text { وتر هب }
$$


- و واستنفرت (زينب) لـّا ر أتكك وطالما كانت تحنّ (تشتاقّ) إلى لقاك و هي تـر هب

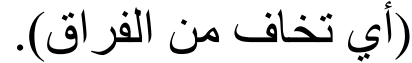

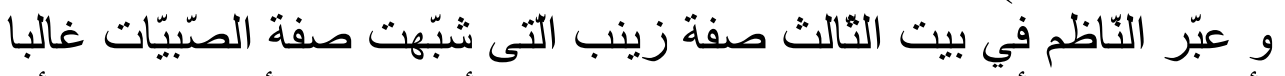

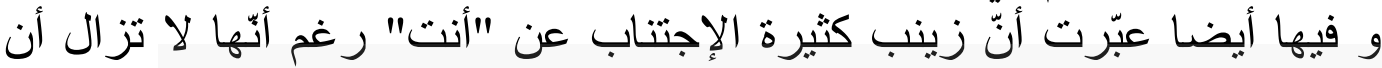

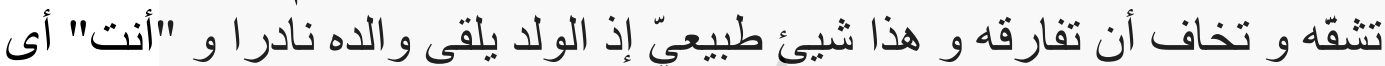

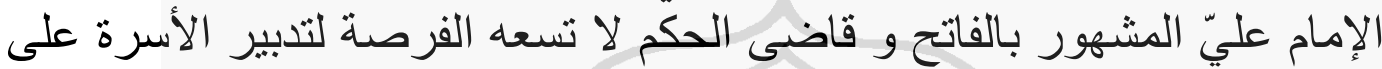

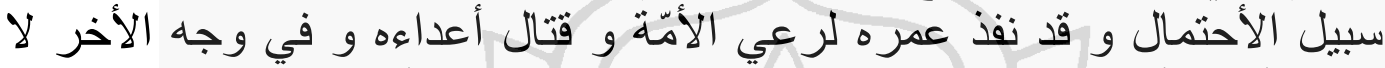

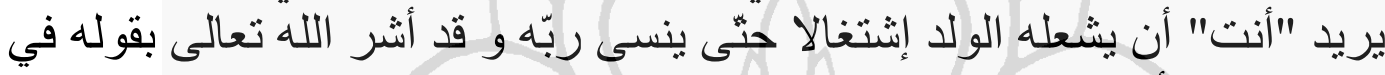
سورة النّوبة أية خمسة و ثناثلثين:

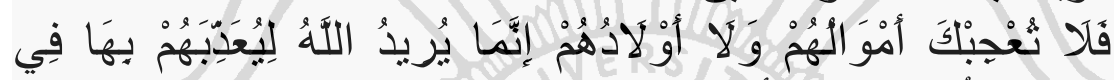

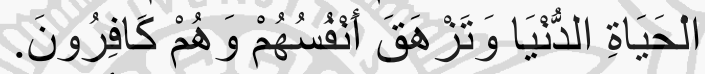

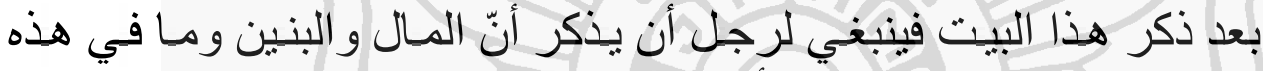

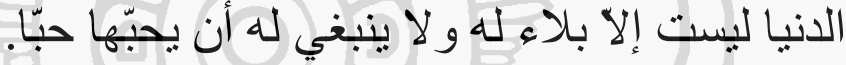

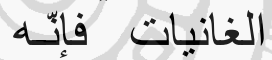

- وكذالك وصدل الغانيات (المرأة الجمبلة) فإنّه أل (سراب) بيلقعـة (صحر اء) وبرق خلّب (برق كاذب).

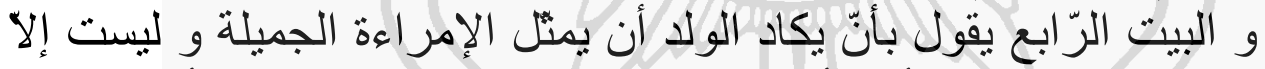

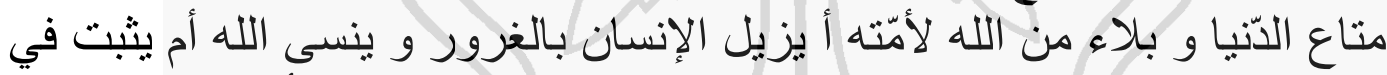

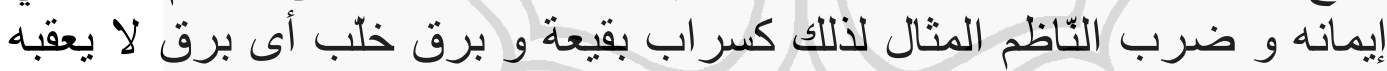
المطر كما قال تعالى في سورة النّور أية التّاسعة و ثنالثين

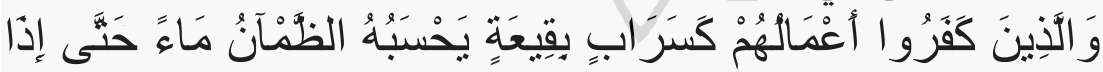

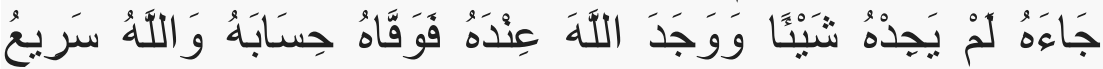

ولذَلكَّبِ فينبغي لكلّ الإنسان كمخلوق عاقل أن بطلب سبيل حقّ لألا بزيل وازهد فعمرك منه ولّى انه

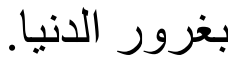

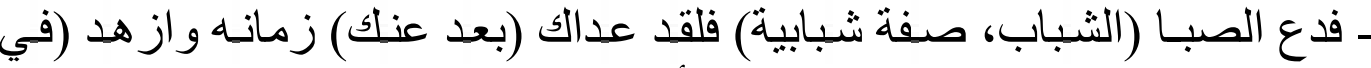

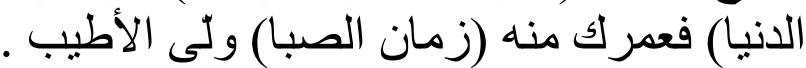

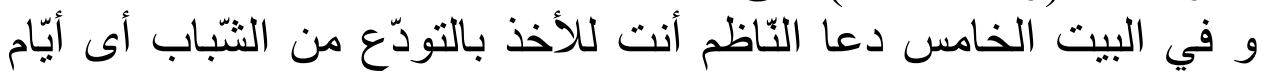

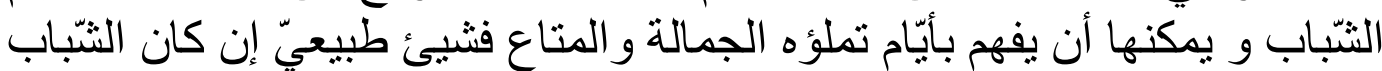
يحبّين التأئس و قلّ إهتمامهم لحياة الأخرة.

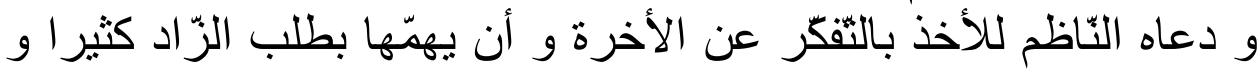

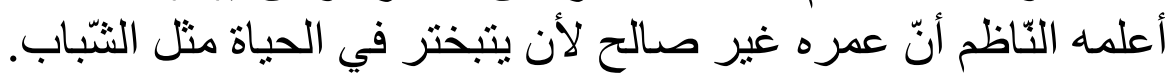


و بعد أن يحلّ الثّعر "الزّبنيبة" لإمام عليّ ابن أبي طالب عليه السّّلام في

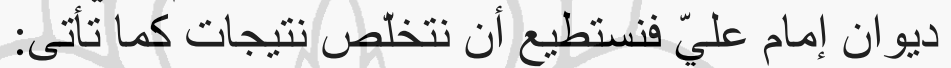

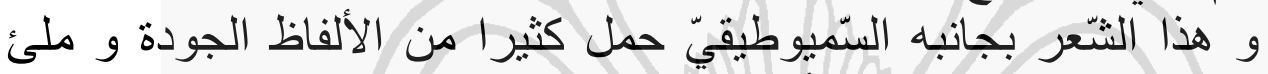

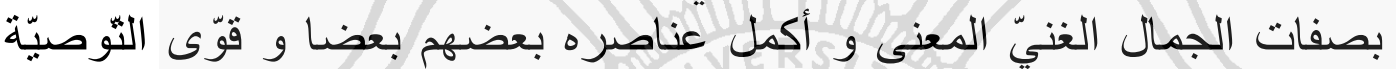
التى طلب الناظم أن بيلغنها لئيا أمّا معانى هذا النثّعر فكما نأني.

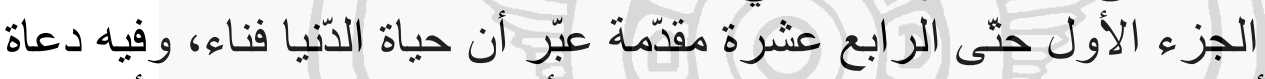

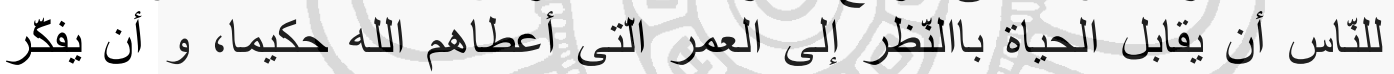
وينظر إلى نفساه. الجزء الخامس عشرة حنّى التّاسع عشرة بحث أنّ الإنسان لا بدّ له الإنتباه لاستعمال الوقت الوت الجزء/العشرون حتى الثالث والعشرون دعاة لتقوى الله ورسوله،

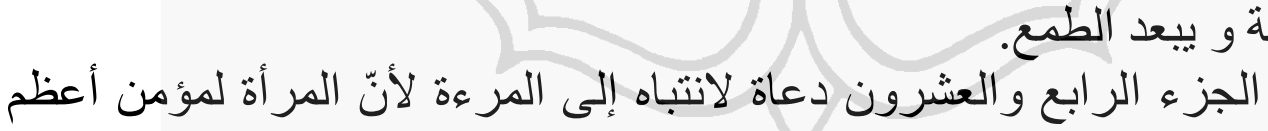

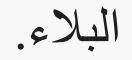
الجزء الخامس و العشرون دعاة لمو اجهة العدوّ بطريقة مكرّمة.

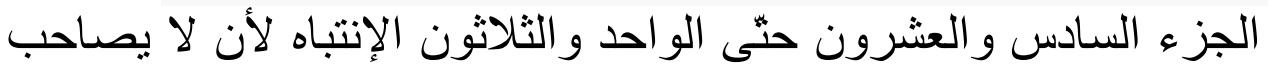

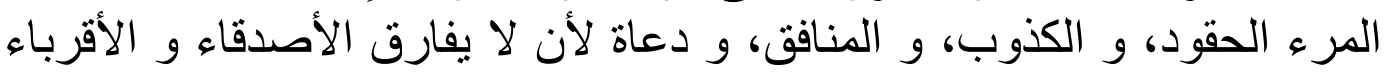
بدرجاتهم المتفرّقة. الجزء الثاني والثلاثون حتّى السادس والثناثون دعاة لينتبه المرأ فى ولى

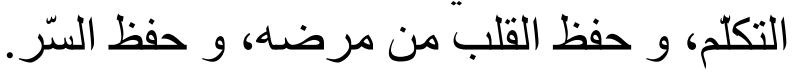

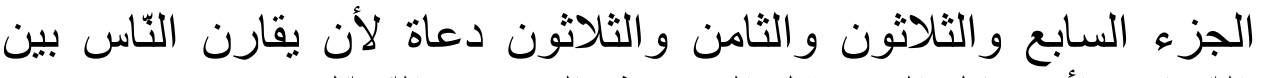

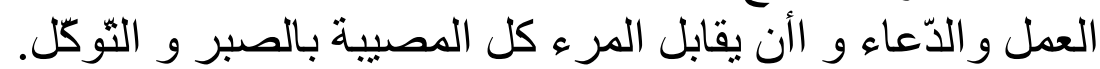

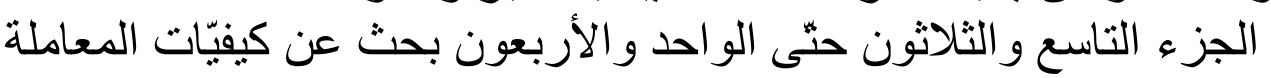
بالمجتمع و الضيوف و المظلاءوم. الجزء الثانى والأربعون بحث عن ضرون الثريّة الهجرة، بالهجرة سيزيد

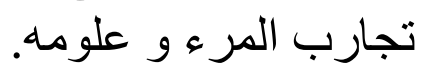


الجزء الثالث والأربعون والر ابع والأربعون تختيم الثعر عبّر أنّ هذا رضي الله عنه

$$
\text { الشعر لائق الإعتماد. }
$$

شعر نصيحة "الزينيّة الإنيّة"

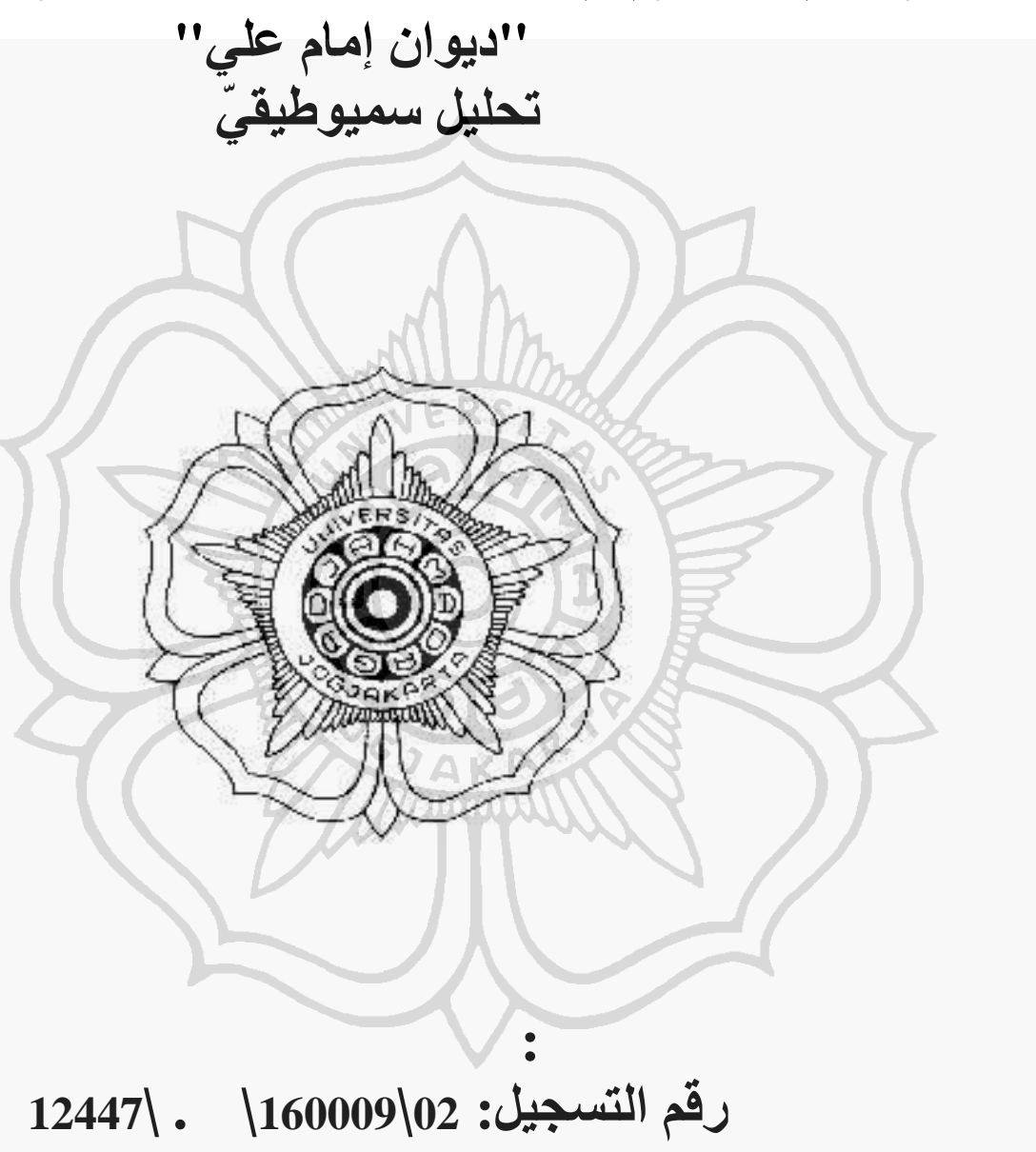

قسم أدب آسيا الغربيّة بكليّة م علوم الثقافيّة بجامعة قاجه مادا يوكياكرتا لئا لئه

2006

شعر نصيحة "الزينبيّة" لإمام علي بن أبي طالب رضي الله عنه

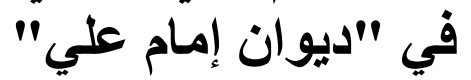
تحليل سميوطيقيّ 


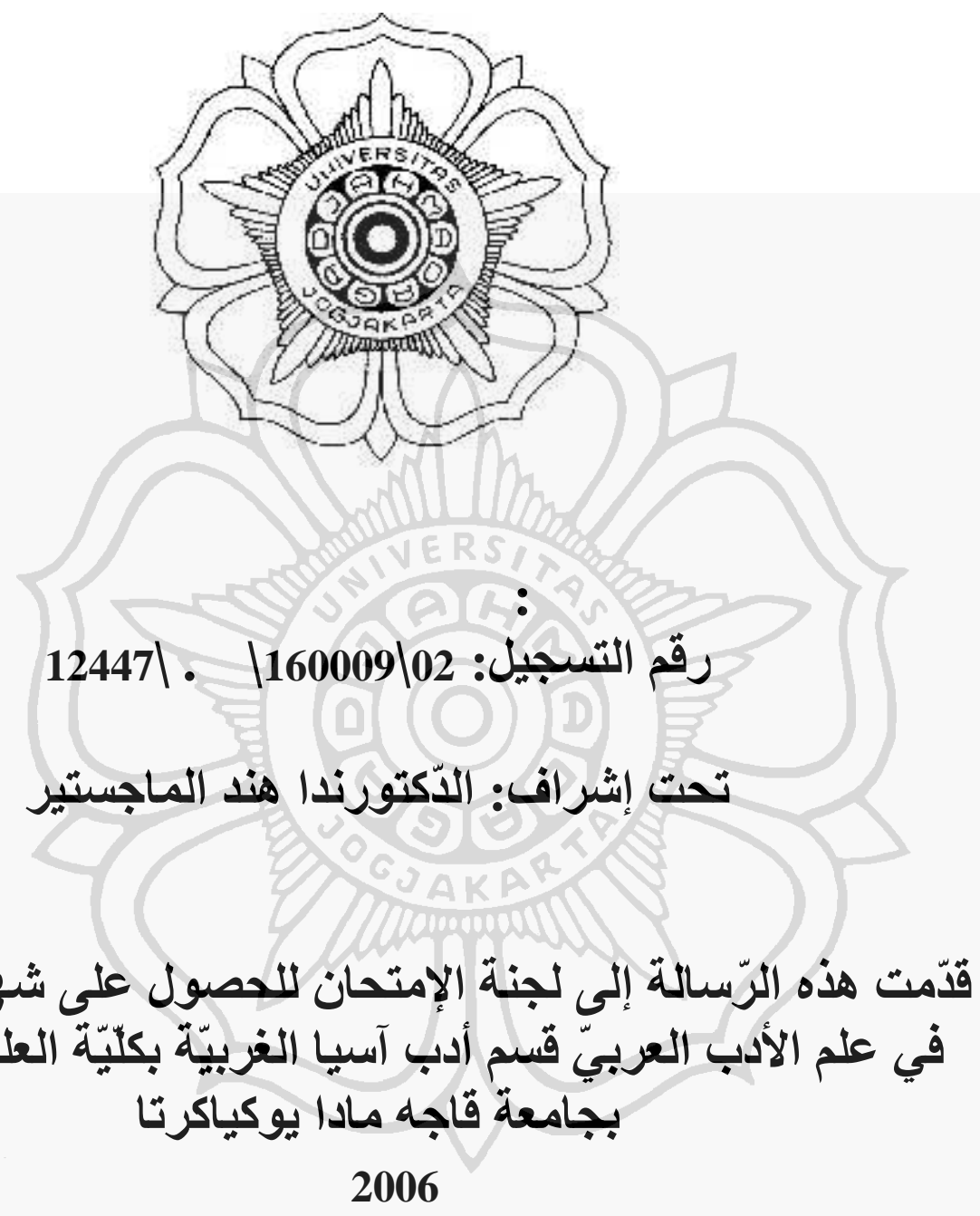

